\title{
ESTUDO FOTOINTERPRETATIVO SOBRE A MORFOMETRIA DAS AREAS DE DOIS SOLOS PODZÓLICOS VERMELHO-AMARELOS
}

\author{
WALTER POLITANO
}

Orientador: GERALDO VICTORINO DE FRANÇA

Tese apresentada à Escola Superior de Agricultura "Luiz de Queiroz", da Universidade de São Paulo, para obtenção do Titulo de Doutor em Solos e Nutrição de Plantas.

PIRACICABA

Estado de São Paulo - Brasil

Agosto, 1980 
A meu pai,

PASCHOAL ANTONIO POLLITANO,

por ter-me ensinado o respeito à dignidade e o amor ao trabalho, DEDICO

(in memorian) 
$\bar{\AA}$

Maria Cecília e Gregório Vicente, meus incentivadores, OFEREÇO 
Ao Professor Doutor Geraldo Victorino de França, pela dedicada orientação e participação na minha formação cien tifica.

Ao amigo, Professor Doutor Paulo Cesar Corsini, pela sua participação na realização deste trabalho.

A Escola Superior de Agricultura "Luiz de Nueiroz" e à Faculdade de Ciências Agrárias e Veterinárias "Campus" de Jaboticabal, pelas oportunidades e facilidades oferecidas.

Aos Professores do Departamento de Solos, Fertili zantes e Geologia da Escola Superior de Agricultura "Luiz de Queiróz", pelo apoio oferecido.

Aos Colegas e Funcionários do Departamento de En genharia Rural da Faculdade de Ciências Agrárias e Veterinárias "Campus" de Jaboticabal, pelas manifestações de coleguismo e apoio.

Aos Colegas Professores Doutores Dilermando Pere cin, David Ariovaldo Banzatto e Juan Ayala Osuna, pelas facili dades oferecidas para a realização da análise estatística.

Ao meu auxiliar, Silvio Moreira, pelos serviços de desenho. 
participação na composição do texto.

A Sra. Nelci Teixeira Maniero e Srta. Miriam Ro sangela Ignácio, pelos seus atendimentos com simpatia e colabo ração nos assuntos ligados ao Curso de Pós-Graduação.

Estendemos, ainda, nossos agradecimentos às fun cionárias do Setor de Pós-Graduação da Escola Superior de Agrí cultura "Luiz de Queiroz" e a todas as pessoas que, de uma for ma ou de outra, tenham contribuido para a realização deste tra balho. 
1. RESUMO $\ldots \ldots \ldots \ldots \ldots \ldots \ldots \ldots \ldots \ldots \ldots \ldots \ldots \ldots \ldots \ldots \ldots$

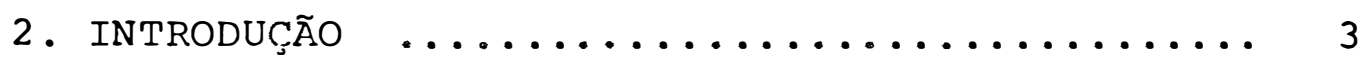

3. REVisão da literatura $\ldots \ldots \ldots \ldots \ldots \ldots \ldots \ldots$

3.1. Aplicação da Fotografia Aérea ....... 4

3.2. Fundamentos da Fotointerpretação $\ldots \ldots .7$

3.3. Análise Morfométrica $\ldots \ldots \ldots \ldots \ldots \ldots 12$

4. MATERIAIS E METOdOS $\ldots \ldots \ldots \ldots \ldots \ldots \ldots \ldots \ldots \ldots$

4.1. Materiais ................. 37

4.2. Métodos $\ldots \ldots \ldots \ldots \ldots \ldots \ldots \ldots \ldots \ldots$

5. RESUltados E discUSSÃO $\ldots \ldots \ldots \ldots \ldots \ldots \ldots \ldots 71$

5.1. Bacias Hidrográficas $\ldots \ldots \ldots \ldots \ldots \ldots 71$

5.2. Redes de Drenagem ............. 89

5.3. Sintese dos Resultados ........... 149

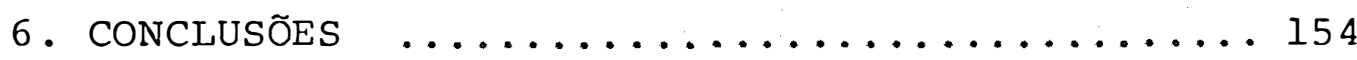

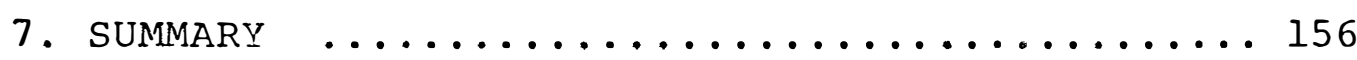

8. Literatura CitadA $\ldots \ldots \ldots \ldots \ldots \ldots \ldots \ldots \ldots$ 
LISTA DE OUADROS

QUADRO

Dáạina

1 Dados Climáticos e Balanço Hídrico Men sal, Segundo Thornthwaite e Matter (1955)

da Região de Jaboticabal. (CAD: $125 \mathrm{~mm}$ )..... 40

2 Dados Climáticos e Balanço Hídrico Men sal, Segundo Thornthwaite e Matter(1955) da Região de Jaboticabal. (CAD: $125 \mathrm{~mm}$ )..... 45

3 Caracteristicas Descritivas do Padrão de Drenagem e Respectivas Categorias, LUE

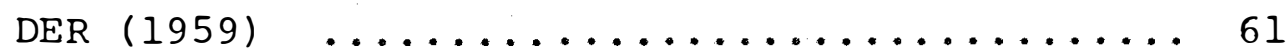

4 Análise Dimensional e Teste de Semelhan ça Geométrica das Bacias Hidrográficas ..... 79

5 Características Não Dimensionais das Ba cias Hidrográficas $\ldots \ldots \ldots \ldots \ldots \ldots \ldots \ldots . \ldots$

6 Valores Médios e Erros padrões da Média das Características Dimensionais das Ba cias Hidrográficas $\ldots \ldots \ldots \ldots \ldots \ldots \ldots . \ldots 2$ 
Análise de Variância das Características

9 Características Dimensionais das Bacias Hidrográficas, Determinadas pela Análise Hipsométrica

10 Análise de Variância das Características Dimensionais Determinadas pela Análise Hipsométrica $\ldots \ldots \ldots \ldots \ldots \ldots \ldots \ldots \ldots$

Caracteristicas Descritivas dos Padrões de Drenagem

12 Características Quantitativas do Padrão de Drenagem, Determinados em Bacias Hi

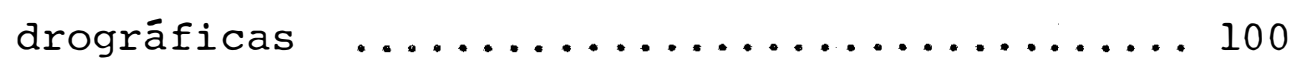

13 Características Quantitativas do Padrão de Drenagem, Determinados em Amostras

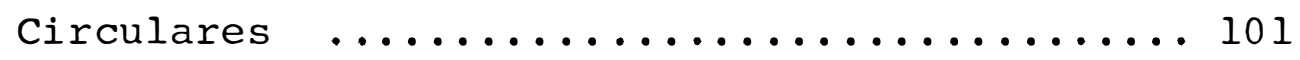


Classes de Textura Topográfica dos pạ drões de Drenagem ................. 102

15 Análise de Variância da Característica Densidade de Drenagem ............... 102

16 Análise de Variância da Característica Frequência de Rios ................... 103

17 Análise de Variância da Característica Razão de Textura $\ldots \ldots \ldots \ldots \ldots \ldots \ldots \ldots$

18 Desdobramento da Interação Solos/Amostra gem da Característica Razão de Textura ..... 104

19 Análise de Variância da Característica Ex tensão do Percurso Superficial .......... 104

20 Desdobramento da Interação Solos/Amostra dem da Característica Extensão do Percur so superficial ................ 105

21 Análise de Variância da Característica Coeficiente de Manutenção .............. 105 
22 Valores Observados do Número de Seg̣men tos de Rios em cada Ordem, Valores do Nú mero Total da Bacia e Valores Médios, ne terminados pela Média Aritmética e Poden rada em Relação às Âreas das Bacias ........ 110

23 Formas Assumidas pela Relação Preconiza da por MAXWELL (1955), pelas Substitui Ções Numéricas dos Números de Segmentos de Rios, Coeficientes de Correlação ( $r$ ), Coeficientes de Determinação $\left(r^{2}\right)$ e $\%$ da Variação Total Explicada $\left(r^{2} \times 100\right) \quad \ldots \ldots \ldots 113$

24 Valores dos Números de Segmentos de Rios em Cada Ordem, Determinados segundo a Mé dia Ponderada em Relação às Áreas das Bacias e Valores Calculados em Função da Relação Preconizada por MAXWELL (1955) e Lei de Horton .................... 114

25 Valores Observados e Valores Médios Cal culados e Determinados pela Relação de MAXWELL (1955), da Razão de Ramificação.... 116 
Valores dos Comprimentos Totais dos Seg mentos de Rios Observados em Cada Ordem e na Bacia e Valores Médios Determinados pela Média Ponderada em Relação às Áreas das Bacias

Formas Assumidas pelas Relações Preconi zadas por FRANÇA (1968) e STRAHLER. (1957), pela Substituição Numérica dos Comp̣imen tos Totais dos Segmentos de Rios, Coefi cientes de Correlação $(r)$, Coeficientes de Determinação $\left(r^{2}\right)$ e a \% da variação Total Explicada $\left(r^{2} \times 100\right) \quad \ldots \ldots \ldots \ldots \ldots \ldots \ldots$

28 Valores dos Comprimentos Totais dos Seq mentos de Rios, Determinados pela Média Ponderada em Relação às Āreas das Bacias, Relações Preconizadas por FRANCA (1968) e STRAHLER (1957) e pela Lei de Horton ...... 121

29 Valores Observados e Valores Médios Cal culados da Razão de Comprimentos Totais de Segmentos de Rios .................... 123 
Valores Médios dos Segmentos de Rios em Cada Ordem e na Bacia e Respectivos Valo res Médios Determinados pela Média Ponde rada em Relação às Areas das Bacias

Formas Assumidas pela Relação Preconiza da por VASQUUES FILHO (1972), pela Substi tuição Numérica dos Dados de Comprimen tos Médios de Segmentos de Rios, Coefi ciente de Correlação (r), Coeficiente de Determinação $\left(r^{2}\right)$ e a $\%$ da Variação Total Explicada $\left(r^{2} \times 100\right)$............. 127

32 Valores Médios de Comprimentos Médios de Segmentos de Rios, Determinados pela Mé dia Ponderada em Relação às Āreas das Bạ cias, Relação Preconizada, Relação Lw/Nw e Lei de Horton .................. 128

33 Valores observados e Valores Médios Cal culados da Razão de Comprimentos Médios, segundo a Média Aritmética e Relação de VASQUES FILHO (1972) 
Números, Comprimentos Totais e Comprimen tos Médios dos Segmentos de Rios Referen

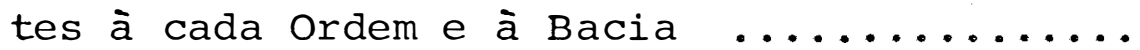

Valores Médios das Razões de Ramificação, de Comprimentos Totais e de Comprimentos Médios, Determinados pela Média Aritmétí ca, Relações Preconizadas e Relação $(\mathrm{Rlm}=\mathrm{Rb} / \mathrm{RlW})$

Valores observados do Número Total de Segmentos de Rios (N e Nc), Comprimentos Totais dos Segmentos de Rios ( $\mathrm{Cr}$ e $\mathrm{Crc}$ ) e Comprimentos Médios dos Segmentos de Rios ( Lm e Lmc) Determinados em Bacias Hidrográficas e Amostras Circulares ....... 135

37 Análise de Variância das Características Números Totais de Segmentos de Rios ( $N$ e Nc), Comprimentos Totais de Segmentos de Rios ( $\mathrm{Cr}$ e $\mathrm{Crc}$ ) e Comprimentos Médios dos Segmentos de Rios ( $\mathrm{Lm}$ e Lmc), Deter minados Respectivamente em Bacias Hidro gráficas e Amostras Circulares ......... 136 
Relações Funcionais Entre as Caracterís ticas Ouantitativas do Padrão e das Ba cias de Drenagem $\ldots \ldots \ldots \ldots \ldots \ldots \ldots$

39 Relações Funcionais entre os f́ndices do Padrão Drenagem, Determinados em Pmos tras Circulares $\ldots \ldots \ldots \ldots \ldots \ldots \ldots . \ldots . \ldots . \ldots 145$

40 Relações Funcionais Entre as Caracterís ticas dos Padrões Drenagem, Determinaras em Bacias Hidrográficas e Amostras Circu

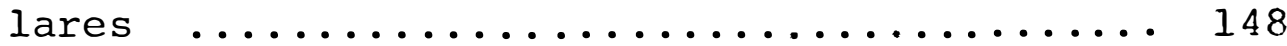


1 Localizações das Areas de Estudo no Estạ do de são Paulo ........................ 39

2 Balanço Hídrico Mensal da Região de Jabọ ticabal

Balanço Hídrico Mensal da Região de Pira cicaba

Bacias Hidrográficas Representativas dos Solos Podzolizados de Lins e Marília var. Marília

5 Bacias Hidrogrāficas Representativas dos Solos Podzolizados de Lins e Marília var. Marilia $\ldots \ldots \ldots \ldots \ldots \ldots \ldots \ldots \ldots \ldots \ldots \ldots$ Solos Podzólico Vermelho-Amarelo - var. Laras 
Bacias Hidrográficas Representativas dos Solos Podzólico Vermelho-Amarelo - var.

Curvas Hipsométricas das Bacias Hidrográ ficas Representativas da Unidade Solos Podzolizados de Lins e Marília - var. Ma

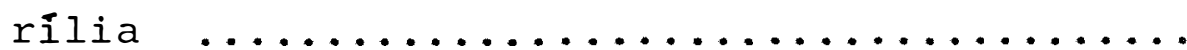

9 Curvas Hipsométricas das Bacias Hidrợáa ficas Representativas da Unidade Solos Podzólico Vermelho-Amarelo - var. Laras ......

10 Amostras Circulares da Pede de Drenagem da Årea de Solos Podzolizados de Lins e

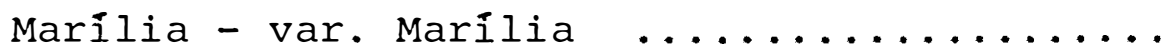

11 Amostras Circulares da Rede de Drenagem da Årea de Solos Podzolizados de Lins e Marilia - var. Marília

12 Amostras Circulares da Rede de Drenagem da Área de Solos Podzólico Vermelho-Ama relo - var. Laras 
Figura

pậina

13 Amostras Ciruclares da Rede de Drenagem

da Ârea de Solos Podzólico Vermelho-Ama

relo - var. Laras ................ 99 
1. RESUMO

Este trabalho foi realizado com a finalidade de avaliar, com o emprego de fotografias aéreas, o significado da análise morfométrica dos componentes da paisagem, relevo e rede de drenagem, na diferenciação de Solos Podzólicos Vermelho-Ama relos, que apresentam como características comuns o mesmo tipo clímático e perfis com horizonte B textural.

As unidades de solos escolhidas foram os Solos Pod zolizados de Lins e Marília - var. Marília e os Solos Podzóli co Vermelho-Amarelo - var. Laras, situados respectivamente, no planalto ocidental paulista, parte centro-norte do Estado de são Paulo e na depressão paleozóica do Estado, zona do médio Tietê. O clima é do tipo mesotérmico de inverno seco, classifí cado como Cwa, pelo sistema de Köeppen.

Representando cada unidade de solo, foram selecio nadas quatro bacias hidrográficas de terceira ordem de ramifi cação satisfazendo o critério de semelhança geométrica de STRA- 
IER (1957) e quatro amostras circulares, com tamanho equivalen te a $5 \mathrm{~km}^{2}$.

A análise e interpretação dos resultados obtidos permitiu que se tirasse as seguintes conclusōes gerais:

a - A análise morfométrica permitiu a diferencia ção das áreas dos solos estudados, refletindo diferenças da re lação infiltração/deflúvio, permeabilidade, armazenamento d'á gua, profundidade do estrato rochoso e diferenças no estágio da erosão;

b - A fotografia aérea foi eficiente para a análi se morfométrica da paisagem dos solos estudados;

c - Os Indices do relêvo foram tão eficientes quanto os índices da rede de drenagem para a diferencjação pre tendida;

d - Os critérios de amostragem utilizados foram adequados para a realização da análise morfométrica, destacandọ -se a superioridade do critério de amostras circulares e,

e - A continuidade dos estudos realizados é neces sária para se verificar até que nível as diferenças entre solos permitem a utilização da análise morfométrica para a diferencia ção de suas áreas de ocorrência. 
2. INTRODUÇÃO

A paisagem terrestre constitui o meio onde se de senvolvem os solos e seus elementos são alguns dos fatores con dicionadores da pedogênese.

A sua caracterização tem sido tradicionalmente fei ta, desde HORTON (1945), com o propósito de considerar os pa péis das relações infiltração/deflúvio dos materiais e dos pro cessos erosivos provocados pelas águas correntes. A partir de FRANÇA (1968), tem-se procurado estabelecer, através da análí se da paisagem, as suas relações com condições específicas de solos, utilizando principalmente a fotointerpretação.

Dentro dessa linha de pesquisa, pretende-se neste trabalho efetuar a análise morfométrica de dois componentes da ṕaisagem, o relêvo e a rede de drenagem, reunindo maior número de informações sobre as suas relações com as condições especí ficas de solos, com o propósito de contribuir para o estabelecí mento dos padrões dos solos nas nossas condições ambientais, a fim de fornecer novos subsídios para a fotointerpretação no le vantamento de solos. 
Este capítulo é apresentado dividido basicamente em três partes. A primeira trata de algumas generalidades sobre a aplicação da fotografia aérea, a segunda diz respeito aos fun damentos da fotointerpretação e a terceira versa sobre a análí se morfométrica na caracterização de bacias e redes de drenagem.

3.1. Aplicação da Fotografia Aérea

\subsubsection{Generalidades}

O uso de fotografias aéreas foi proposto inicial mente para a elaboração de mapas topográficos por Arago em 1840 e teve como suporte o exaustivo programa desenvolvido por Laus sedat a partir de 1850 .

Ao redor de 1858 Mcydenbauer iniciou a aplicação da fotogrametria na arquitetura e o uso da fotografia, para a definição de roteiros, foi empregado desde 1853, antes mesmo da 
guerra civil americana. Após o término deste conflito, a foto grafia aérea passou a ser empregada em levantamentos geológicos, sendo na década de 20 do presente século, utilizada principal mente na pesquisa do petróleo.

Ainda nesta década, generalizou-se o uso da foto grafia aérea nos diferentes ramos da ciência, particularmente na agricultura e principalmente com propósitos específicos de mapeamento. QUACKENBUSH (1960), DAVIS et alii (1966) e FISCHER et alii (1975).

AVERY (1968) apresentou uma lista compilada da Sociedade Americana de Fotogrametria onde constaram 58 áreas de aplicação da fotografia aérea, desde a engenharia aeronáutica, agronomia, ecologia, hidrologia e classificação de terras até a zoólogia. Entretanto, DAVIS et alii (1966) observaram que o maior desenvolvimento desta ciência está no campo do levantamen to aerofotogramétrico.

Em particular, com respeito à aplicação da foto grafia aērea no Brasil, destacam-se os esforços do governo bra sileiro na área da Amazônia, onde foram realizados levantamen tos sistemáticos pelo projeto RADAM, de uma faixa territorial de dois milhões de quilômetros quadrados, com o propósito de se elaborar mapas e cartas topográficas, cartas de vegetação, da geologia, de geomorfologia, de solos e da drenagem superficial, entre outros, PAIVA et alii (1976). 
Por volta de 1885 iniciaram-se nos Estados Unidos da América os levantamentos de solos, sendo que quarenta anos após, Cobb chamava a atenção dos cientistas para as possibilida des da aplicação da fotografia aérea, nesta finalidade, BURINGH (1954). Entretanto, a primeira aplicação da fotografia aérea foi realizada no Condado de Jennings, no Estado de Indiana, so mente em 1929, cabendo a Bushnell e colaboradores a primasia da sua utilização no mapeamento de solos, fato este que se genera lizou desde a metade dos anos trinta, SERVICIO DE CONSERVACION DEL SUELO (s/d) e BOMBERGER e DILL (1960).

No Brasil, embora os estudos de solos tenham sido iniciados a partir de 1935, pelo Instituto Agronômico da Secre taria da Agricultura do Estado de São Paulo, localizado na cida de de Campinas, somente a partir de 1960 a fotografia aérea co meçou a ser empregada para esses fins, época em que as primei ras coberturas aerofotográficas dos estados se tornaram dispo níveis. Foram realizados inúmeros levantamentos a diferen tes niveis de generalização nas diversas regiões do país, destą cando-se, particularmente, os levantamentos pedológicos de vâ rios municípios do Estado de são Paulo, realizados pelas equi pes pertencentes ao Instituto Agronômico e à Escola Superior de Agricultura "Luiz de Queiróz" - USP, RANZANI et alii (1966), PAIVA et alii (1976) e OLIVEIRA et alii (1979). 
3.2. Fundamentos da Fotointerpretação

A fotointerpretação é definida por QUACKENBUSH (1960) como o ato de examinar imagens fotográficas com o propó sito de identificar os objetos e avaliar os seus significados e SUMMERSON (1954) a definiu como a previsão daquilo que não po de ser realmente visto.

Na fotointerpretação é adotado o princípio da con vergência de evidências, preconizado por COLWELL (1952), o qual estabeleceu que existem vários indícios sobre a identidade de um objeto desconhecido e, se a maioria deles aponta para a mes ma conclusão, esta será provavelmente a correta.

Dentre os fatores empregados na identificação dos aspectos da fotografia aérea, AVERY (1968) relacionou a forma, tamanho, tom fotográfico, padrão, sombra, posição topográfica e a textura, sendo estes aspectos considerados por BOMBERGER e DILL (1960) como características qualitativas:

No exame da imagem fotográfica se utilizam as téc nicas da fotoidentificação, fotoanālise e da fotointerpretação, LUEdER (1959). Pela fotoidentificação são reconhecidos os obje tos e as suas localizações no terreno; a fotoanálise complemen ta a fotoidentificação pela adição de uma avaliação por nume rais e pelo estabelecimento de uma interrelação de aspectos, classificando-os pelos seus tamanhos, posições e uso e, final mente, a fotointerpretação realiza uma avaliação dedutiva e in 
dutiva, baseada nas experiências do fotointérprete e nas obser vações de campo.

Três fatos fundamentais, segundo RABBEN (1960) sin tetizam as vantagens do uso da fotografia aérea na caracteriza ção da superfície terrestre, a saber: 1) a cobertura de grande ārea da superfície em cada fotografia; 2) a exibição da imagem tridimensional da superfície e dos objetos e, 3) a representa ção real dos ubjetos na imagem fotográfica. Com respeito à ima gem estereoscópica da paisagem, GOOSEN (1968) afirmou que esta revela os aspectos principais do terreno de maneira mais efi ciente do que aquela observada pela visão normal, devido ao exa gero proporcionado pela imagem tridimensional. $\bar{A}$ respeito da sensibilidade da imagem fotográfica para o registro dos deta lhês do terreno, AB'SADER (1960) salientou que esta proprieda de depende muito das condições de clima da região onde foi realizada a cobertura aerofotográfica. Nas regiões de clima se co o número de informações conseguidas através do exame da fô tografia aérea é muito maior ao das regiões de clima úmido.

Na caracterização dos solos de uma ärea, torna-se importante ao fotointérprete o conhecimento dos processos natu rais e culturais de suas formações, FROST (1960). Neste senti do RAY (1963) ressaltou a importāncia da forma fisiográfica na fotointerpretação de solos porque esta é baseada principalmente nas afinidades existentes entre os solos e os aspectos geomórfi cos de suas áreas de ocorrência, os quais fornecem indícios so 
bre seus processos formadores.

De acordo com GOOSEN (1968) verificou-se que os aspectos inerentes ao solo podem ser estudados vantajosamente pelo emprego da fotografia aérea, através do conhecimento das relações existentes entre os solos e as características físicas e culturais da área. Assim, as fotografias aéreas são amplamen te usadas para obter informações e para delimitar tipos ou clas ses de solos, porque elas revelam indícios sobre a forma da su perfície, a vegetação e a cor do solo, SERVICIO DE CONSERVACION DEL SUELO (s/d). Permite ao pedölogo a orientação no campo, a demarcação dos solos, além de facilitar a preparação da car ta base para o mapeamento, BOMBERGER e DILL (1960). Segundo es tes autores, a maioria dos aspectos físicos da superfície ter restre, como o relevo, a drenagem, os padrões de erosão e a ve getação revelam ou sugerem a distribuição dos solos e de seus materiais de origem.

RAY e FISCHER (1960) salientaram a utilidade da observação estereoscópica ao afimarem que a fonna tridimensional da imagem fotográfica supera os mapas topográficos como fonte de informações, devido à quantidade de detalhes nela contidos. A fotografia aérea contudo, apresenta a limitação de não permitir a visualização do solo em sua forma tridimensional, mostrando somente a sua superfície e, ainda, de maneira imperfeita, SER VICIO DE CONSERVACION DEL SUELO (s/d). As interferências na ima gem fotográfica, de diferentes naturezas, mascaram as proprie 
dades reais da superfície do solo, tornando a fotointerpretação pedológica completamente diferente daquela de outras áreas de estudo, onde os objetos são parcial ou totalmente vistos na fo tografia. Neste caso, os solos somente podem ser interpretados pelo estudo de padrões fotográficos relacionados ao material de origem, modo de deposição e aos meios climático, biótico e fí siográfico, FROST (1960).

Ainda com respeito às limitações da fotografia aérea nos estudos do solo, Goosen (1968) observou que as difé renças entre tipos, fases e, muitas vezes, séries de solos, não são sempre visíveis na superfície terrestre. Este fato permitiu deduzir que, em levantamentos detalhados a fotointerpretação apresenta valor limitado, o que pode ser verificado pelos critê riós e definições de levantamentos, desde os esquemáticos até os detalhados, constantes em MARQUES (1971). A limitação da utị lidade da fotografia na interpretaçăo de solos foi sintetizada por FROST (1960), que a relacionou aos fatores inerentes às téc nicas dos materiais fotográficos, às limitações humanas e aos inerentes à própria superfície terrestre fotografada. Particu larmente, com referência à qualidade da fotografia aérea, GAR CIA (1979), citando Dutton em 1967, ressalta as vantagens da fo tografia pancromática na caracterização da paisagem. Todavia, é no traçado mais exato dos limites do solo e no maior rendimen to dos mapeamentos, que a fotografia aérea encontra sua grande utilidade, ROURKE e AUSTIN (1951), CRESWICK e ROCKWELL (1959), 
BOMBERGER e DILL (1960), BURINGH (1960), GOOSEN (1968) e AUDI (1972) .

Referindo-se à metodologia para a fotointerpreta ção, GOOSEN (1968) apresenta três métodos para levantamento de solos: 1) método da análise dos padrões; 2) método da análise dos elementos e, 3) método da análise fisiográfica.

O primeiro deles, método da análise dos padrões, parte da suposição que cada elemento padrão está relacionado com certas condições do solo. Os elementos padrões considerados são a forma do terreno (relevo), a drenagem, os aspectos erosi vos, a vegetação, a tonalidade fotográfica e os aspectos cultu rais. Por este método, a partir da identificação das grandes unidades se atinge as menores, sendo estas últimas caracteriza das pelos chamados padrões locais. O segundo, método da análí se dos elementos, está fundamentado na análise sistemática dos elementos que se relacionam às condições do solo, cuja classí ficação resultante é usada como base para o trabalho de campo. o terceiro método, o da análise fisiográfica, baseia-se num co nhecimento profundo dos processos fisiográficos e suas expres sões fotográficas. Por este último método, o terreno é classifi cado em unidades fisiográficas, sendo que cada uma delas contém uma associação de solos. 


\subsection{Anālise Morfométrica.}

3.3.1. Histórico e leis

O desenvolvimento dos processos sistemáticos e ra cionais com o propósito de caracterizar as formas do relevo deu -se nos países germânicos, particularmente na Austria, Alemanha e Suiça, no século XIX, alcançando grande evidência no final deste século. Entretanto, as contribuições dessa fase da morfo metria pouco representaram na evolução dos conhecimentos, inclu sive como metodologia de pesquisa, por preocupar-se quase que exclusivamente com a orometria.

Esta linha de estudos morfométricos foi suplantada pelas novas concepções geomorfológicas procedentes da Amérí ca, relacionadas com as idéias de William Morris Davis e por outras já existentes na própria Europa, particularmente na Ale manha, tendo como ponto de partida o trabalho de Robert E. Hor ton, em 1945, que procurou estabelecer as leis do desenvolvimen to dos rios e suas bacias interpretando a lei de playfair em bases quantitativas. Essa renovação metodológica originou novas pesquisas, com inúmeros seguidores, ocorrendo uma expansão da morfometria marcadamente nos Estados Unidos da América e com re percussão nos países europeus, citando-se dentre eles a França, CHRISTOFOLETTI (1969).

No Brasil os estudos morfométricos iniciaram 
com FREITAS (1952) ao apresentar um trabalho sobre textura topo gráfica e teve continuidade com o trabalho de TOLENTINO, GANDOL FI \& PARAGUASSU (1968), que publicaram um estudo sobre as ba cias hidrográficas do planalto de São Carlos - SP. Nesse mesmo ano, FRANÇA (1968) os aplicou na caracterização de bacias e re des de drenagem, empregando fotografias aéreas, relacionando suas características à condições de solos. A contribuição de França foi de grande importância sob o ponto de vista metodoló gico e interpretativo, sendo adotado por diversos pesquisado res, como MARCHETTI (1969), FADEL (1972), VASQUES FILHO (1972), CARVALHO (1977) e outros, abrindo novos caminhos dentro da foto interpretação.

Reportando-se ao trabalho de HORTON (1945), foi apresentado um tipo de caracterização, de natureza quantitati va, das bacias e redes de drenagem, segundo uma aproximação hi drofísica em que foram consideradas as reiações infiltração/de flúvio e os processos erosivos provocados pelas águas correntes. Este autor inverteu a notação do sistema europeu de ordem de rios, propôs uma definição para composição da rede de drenagem e correlacionou o número e o comprimento de rios com as diver sas ordens de ramificação da rede, estabelecendo desta maneira, as leis do desenvolvimento dos rios e suas bacias.

Assim, a lei do número de rios expressa a relação entre o número de rios de uma dada ordem e a respectiva ordem, em termos de uma série geométrica inversa, em que o primeiro 
termo é a unidade e a base é a razão de bifurcação (Rb). A lei dos comprimentos de rios expressa a relação entre os comprimen tos de rios de uma dada ordem e a respectiva ordem em termos de uma série geométrica direta, em que o primeiro termo é o compri mento médio dos de primeira ordem.

Posteriormente, SCHUMM (1956) estabeleceu que a área de uma bacia de drenagem aumenta exponencialmente com $\circ$ au mento da ordem de ramificação dos rios, à semelhança da lei dos comprimentos de rios estabelecida por Horton. A área foi consi derada por ANDERSON (1957) como a variável mais importante da bacia hidrográfica, visto que a maioria das outras característi cas da bacia a ela estão relacionadas.

\subsubsection{Bacia Hidrográfica}

\subsubsection{Conceituação}

Já ao redor de 1500 DC, Leonard da Vinci escrevia que "cada vale foi escavado pelo seu rio e a relação entre os vales é a mesma que existe entre os rios" e playfair em 1802 ob servava que cada rio consistia num tronco principal alimentado por um certo número de tributários, sendo que cada um deles ocorria num vale proporcional ao seu tamanho e o conjunto forma va um sistema de vales comunicantes, com declividades tão per feitamente ajustadas que nenhum deles se unia ao vale principal 
num nível demasiadamente superior ou inferior. Circunstância es ta que seria infinitamente improvavel se cada vale não fosse obra do rio que o ocupa, HORTON (1945), STRAHLER (1957) e CHRIS TOFOLETTI (1969).

A bacia hidrográfica foi definida, segundo GUERRA (1969) e RUHE (1975), como um conjunto de terras drenadas por um rio principal e seus afluentes, tendo um divisor d'āgua que a delimita, separando-a das bacias adjacentes. De acordo com RUHE (1975), a bacia de drenagem constitui uma unidade geomórfica fundamental, onde todo o fluxo da āgua superficial é governado por suas propriedades. A bacia tem propriedades geométricas on de numa análise de sistemas naturais os dados hidrológicos, de erosão e de sedimentação podem ser relacionados.

Com o propósito de contornar as restrições de HOR TON (1945) e SMITH (1950), referentes às variações de áreas, STRAHLER (1957), além de propor a análise de bacias da mesma ordem de ramificação, preconizou um conceito sobre a similaridâ de das bacias. Por esse conceito, em bacias geometricamente si milares todas as medidas de comprimento entre os pontos corres pondentes conduzem à fixação de uma escala proporcional e todos os ângulos correspondentes são semelhantes. Segundo este autor, as bacias apresentaram similaridade somente nos meios ambientes onde ocorria homogeneidade de rochas. A vantagem da aplicação deste princípio como base de operação é que, em decorrência dẹ le, as diferenças da escala linear são independentes da forma 
ou propriedades da forma da bacia e as diferenças de forma inde pendem das diferenças de tamanho. Pelo conceito de similaridade fica estabelecido que os ângulos correspondentes são semelhan tes, sendo $\left(\alpha=\alpha^{\prime}\right)$ e $\left(\beta=\beta^{\prime}\right)$; que as relações entre perímetros (p), comprimentos (c), larguras (1) e relevos (h) fixam uma pro porção $\lambda=\mathrm{p} / \mathrm{p}^{\prime}=\mathrm{c} / \mathrm{c}^{\prime}=1 / \mathrm{l}^{\prime}=\mathrm{h} / \mathrm{h}^{\prime}$; que a relação entre áreas

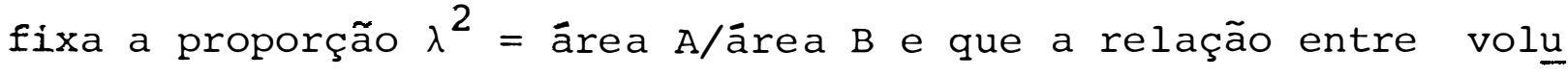
mes estabelece a proporção $\lambda^{3}=$ volume $A /$ volume B. As dimensões comprimento, largura, perímetro, relevo, área e volume são usa das singularmente ou em combinação.

\subsubsection{Relevo}

Segundo GUERRA (1975) o relevo foi conceituado co mo uma diversidade de aspectos da superfície da crosta terres tre representada pelo conjunto dos desnivelamentos. Na geologia e geomorfologia o relevo é considerado como um termo descriti vo, sujeito a explicação e interpretação, sendo usado como si nônimo de paisagem e, na topografia, o relevo é considerado co mo a distribuição das diferenças de cotas ou altitudes existen tes entre os pontos da superfície.

BUOL et alii (1973), adotando a definição do Soil Survey Staff de 1951, considerou o relevo para fins do estudo da gênese do solo como "as elevações ou variações da superfície terrestre consideradas coletivamente", a topografia como "aque les aspectos do terreno representados num mapa topográfico" e o 
declive, como o ângulo que alguma parte da superfície terrestre faz com um "datum" horizontal.

O relevo foi classificado pelo tamanho em três or dens, adotando-se o sistema de von Engeln. Por este sistema, as formas de relevo de primeira ordem são constituídas pelas dos continentes e das bacias oceânicas, as de segunda ordem pelas das planícies, platôs e cadeias de montanhas e as de terceira ordem são formadas pelos vales, bacias, penhascos, depressões, etc., LUEDER (1959). Este autor considerou que em termos de in terpretação, as formas de relevo de terceira ordem são satisfa tórias somente para os propósitos da geomorfologia, não apresen tando significado em termos de interpretação prática. Em razão disto, Lueder sugeriu a inclusão da categoria de quarta ordem, for̂mada por aspectos do terreno de ocorrência em áreas relativa mente pequenas, tendo expressão topográfica definida e estando geneticamente relacionadas com a composição e ou formação do ma terial onde ocorrem, devendo repetir-se frequentemente.

De acordo com FROST (1960), a maioria dos relevos têm características distintivas que são claramente visíveis, co mo, por exemplo, os relevos da deposição que frequentemente pos suem características tão estreitamente relacionadas com o modo de deposição do material que as propriedades das formações su perficiais podem ser interpretadas indiretamente através de suas identificações.

A interação entre o relevo e a pedologia foi esta belecida em razão do mesmo constituir-se no meio onde se desen 
volvem os solos, sendo um dos fatores condicionadores da pedogê nese, PENTEADO (1978). A pedogênese ocorre num meio submetido a ações morfogenéticas e, num determinado instante, o solo repre senta o balanço momentâneo entre duas forças antagônicas repre sentadas pela alteração do substrato, que fornece os materiais e, pela ablação, que os remove. O relevo afeta significativamen te o comportamento da água no meio ambiente, modificando as con dições de gênese do solo, fato este que conduziu os pedólogos a estabelecerem o conceito de catena. A superfície topográfica, segundo AVERY (1968), desempenha importante papel nos levantame $\underline{n}$ tos de solos porque proporciona uma chave para a dedução dos processos formadores do solo de ocorrência numa dada região. GOOSEN (1968) salientou que o relevo apresenta alta relação com as condições do solo e alta coincidência com os seus limites, além de apresentar alta visibilidade na imagem estereoscópica.

Com respeito à relação entre propriedađes do solo e relevo, BUOL et alii (1973) afirmaram que as propriedades, tais como, profundidade, espessura das camadas, conteūdo de ma terial orgânico do horizonte A, umidade, cor, grau de diferen ciação dos horizontes, reação do solo, conteūdo de sais solú veis, espécie e grau de desenvolvimento de "pans", temperatura e a natureza do material de origem estão comumente relacionadas com o relevo dentro de áreas geográficas específicas. Segundo esses autores, a verificação dessas relações pode ser realizada por meio da caracterização dos vārios índices, a densidade de drenagem, índice de relevo, dimensões do corpo do solo, número 
de corpos de solos por unidade geomórfica, características do perfil do solo e da distribuição dos solos numa topossequência. Quanto à distribuição dos solos na topossequência, segundo RUHE (1969) podem existir relações com o nível do lençol freático, com a vegetação e com o microclima, singularmente ou combinadas.

3.3.2.3. Rede de drenagem

A rede de drenagem consiste num sistema interliga do de canais de drenagem, sendo formada por um canal principal e seus tributários, RUHE (1975). Segundo GUERRA (1975) é defini da em termos da disposição do traçado dos rios e dos vales. A definição de Guerra se assemelha bastante à de RUHE (1975) para o padrão de drenagem, o qual foi definido como "o desenho pla nimétrico da rede de drenagem".

A análise da rede de drenagem permite a compreen são e elucidação de numerosas questões geomorfológicas, porque os cursos d'água são processos morfogenéticos bastante atuantes na esculturação da paisagem terrestre. A sua importância na geo morfologia clássica e nos estudos cartográficos e aerofotogramé tricos pode ser mostrada pelo fato da drenagem encontrar-se in timamente relacionada, como fator analítico, à erosão, outro elemento fisiográfico e geomorfológico de extraordinária impor tância, CHRISTOFOLETTI (1969).

Os padrões de drenagem retratam a distribuição da 
água na superfície do solo, proporcionando indícios sobre a com posição e origem dos solos, além de poderem ser facilmente delí neados nos pares estereoscópicos de fotografias aéreas, FROST (1960). Segundo LUEDER (1959) esses padrões são, apōs o relevo, os mais consistentes indicadores das condições do solo disponíveis ao fotointérprete. De acordo com AVERY (1968), a classificação dos padrões dentro de agrupamentos regionais espe cíficos propicia o estabelecimento de referências sobre 0 tipo de solo, a estrutura geológica e a quantidade e intensidade de precipitação local.

o padrão de drenagem superficial. é função da relą ção infiltração/deflúvio da água nas áreas de ocorrência dos mạ teriais. Em geral, materiais relativamente impermeáveis, como a argila e argilitos, condicionam a formação de rede relativamen te densa e, materiais relativamente permeáveis, com os arenitos e cascalhos, provocam a formação de rede pouco desenvolvida, existindo, entretanto, exceções, LUEDER (1959). A existência dessas exceções foi atribuida por FRANÇA (1968) às diferentes condições de solo que podem, às vezes, ocorrer em ăreas com si milaridades de materiais e modos de deposição. BELCHER apresentou o conceito de drenagem funcional para explicar por que certos solos argilosos se comportam como se fossem consti tuídos de materiais grosseiros.

o padrão de drenagem revela sobre a permeabilida de e textura dos materiais, a ocorrência de materiais distintos, 
- grau de uniformidade, a localização e extensão das mudanças, os fatores de controles gerais ou localizados, a natureza e pro fundidade das camadas rochosas ou camadas endurecidas, a estru tura geológica e outros aspectos do terreno. Sua análise pode indicar as variações das i.dades das superfícies de erosão e pos sibilitar a interpretação dos diversos aspectos específicos da camada superficial da crosta terrestre, LUEDER (1959), REEVES et alii (1975) e RUHE (1975).

O padrão de drenagem é influenciado pela profun didade do estrato rochoso e pelas declividades das superfícies. De maneira geral, com a diminuição da profundidade do estrato rochoso e pelo aumento das declividades ocorre aumento no núme ro de rios e diminuição no comprimento médio dos rios, além de alterar a distribuição dos rios, SOUZA (1975), CARVALHO (1977) e FREIRE (1977) .

Onde a ação do controle estrutural é mínimo o pa drão de drenagem é influenciado pela espessura e natureza do ma terial exposto, refletindo diferenças dos perfis de solos, RAY (1963), fato que foi parafraseado por GALHEGo (1979). A influên cia da diferença textural dos horizontes A e B do solo nos fe nômenos erosivos, citada por ESPINDOLA (1977), é um importante elemento para a definição do padrão de drenagem.

A importância da caracterização do padrão de dre nagem é inquestionável, todavia, AVERY (1968) ressaltou a limí tação decorrente das inúmeras variações dos padrões nos siste 
mas de drenagem, podendo até ocorrer um único sistema de drena gem apresentando vários padrões. Portanto, o padrão de drenagem é somente um bom indicador das condições de solo, do material de origem e da estrutura litológica subjacente, quando prevale ce numa dada unidade geomórfica.

\subsubsection{Caracterização descritiva}

\subsubsection{Relevo}

Dos diversos sistemas de classificação do relevo, GUERRA (1975) descreveu os de von Engeln, de Siegfrieć Passar ge, de Lobeck e de Paul Macar.

O sistema de von Engeln adota o critério estrutú ral para classificar as unidades geomorfológicas, apresentando a seguinte chave de classificação:

A - Unidade de estrutura simples ou horizontal

1. constituída por sedimentos soltos - planí cie costeira, planície de piemonte, planície de tundra, planí cies fluvial e lacustre, planície glacial e planície de loess;

2. constituída de rochas sedimentates ou mag máticas mais ou menos consolidadas - planaltos interiores, ba cias em forma de concha, planície de lava e cones vulcânicos;

3. constituída por terrenos calcários - for mas cársticas e ilhas coralígenas e, 

B - Unidade de estruturas deslocadas ou perturba das

1. constituída por terrenos dobrados ou fratu彑 rados, com rochas consolidadas - saliências em domo (lacólitos e batólitos) e montanhas dobradas e fraturadas;

2. constituída por massa rígida de terrenos muito antigos, como os escudos de rochas plutônicas e metamórfí cas, as regiões peneplanizadas e as geleiras continentais.

O sistema de Siegfried Passarge enquadra as for mas de relevo nas categorias planície, formas acidentadas e for mas de escavação. As formas acidentadas são compostas pelos cí mos em pontas e pelos montes tabulares e nas formas de escava ção são agrupadas as grutas, cavernas, os vales e as fossas.

O sistema de Lobeck classifica as formas de rele vo em quatro categorias:

1 - formas de primeira ordem ou maiores (conside rável grau de permanência) - formas continentais e bacias oceâa nicas;

2 - formas de segunda ordem ou de construção-pla nícies, planaltos, montanhas e formas vulcânicas;

3 - formas de terceira ordem ou de destruição-for mas de agradação, vales, bacias, escarpas e cristas e,

4 - formas intermediárias compostas e complexas colinas. 
O sistema de classificação de Paul Macar enquadra as formas de relevo nas categorias planície, planaltos e monta nhas. Na categoria planície são agrupadas as planícies coste ras ou maritimas e as continentais; na categoria planaltos, os planaltos típicos, os soerguidos e os baixos-planaltos e na ca tegoria montanhas, são reunidas as montanhas de origem orogêni ca (típicas), as de origem espirogênicas (que constituem mais comumente as bordas de planaltos) e as montanhas de acumulação. Com o propósito de caracterizar o relevopara fins de levantamentos pedológicos, O SERVICIO DE FOMENTO Y CONSERVA CION DE RECURSOS DE SUELOS (1977) apresentou a seguinte sequên cia para a sua descrição: altitude, posição fisiográfica do lu gar (patamar, topo, escarpa, terraço, fundo de vale, planície, depiressão, etc.), forma de vertente, topografia do terreno cir cundante (classe de relevo), microtopografia natural ou artifi cial e declividade local. Em LEMOS e SANTOS (1976) foram apre sentadas as classes de relevo, plano, suave ondulado, ondulado, forte ondulado, montanhoso e escarpado com o fim de caracteri zar a topografia dentro de uma unidade geomórfica.

\subsubsection{Rede de drenagem}

As redes de drenagem são caracterizadas pela anā lise e classificação de seus padrões e componentes, RUHE (1975). Para a classificação dos rios foram propostos 
três sistemas, o europeu, o de Horton modificado por strahler, HORTON (1945) e STRAHLER (1957).

Pelo sistema europeu, o rio principal ou tronco, caracterizado por ser o maior e o mais ramificado, foi designa do como de primeira ordem e os tributārios menores, em sequên cia crescente na sucessão de ramificação, foram enquadrados nas ordens mais elevadas. Este sistema apresentou o inconveniente de classificar em categorias diferentes os tributários não rami ficados localizados nas pontas dos sistemas de drenagem, apesar desses tributários possuirem características semelhantes em to dos os sistemas.

O sistema de Horton apresenta uma inversão em re lação ao sistema europeu. Os tributários não ramificados das pontas dos sistemas de drenagem foram designados de primeira or dem, os tributários que recebem os de primeira ordem foram clas sificados de segunda ordem e os que recebem os de segunda ordem, de terceira ordem e, assim sucessivamente. O autor estabeleceu um critério baseado nas características dos ângulos formados em relação ao prolongamento do canal formado pela junção dos tribu tārios, para a caracterização do rio de ordem mais elevada, sen do considerado o de ordem mais elevada aquele tributário cujo ângulo for menor e quando os ângulos forem iguais, será conside rado de ordem mais elevada o tributário que tiver o maior com primento, HORTON (1945).

O sistema de Strahler foi baseado no sistema de 
Horton, apresentando algumas modificações. Neste sistema os ca nais extremos, de fluxos permanente ou intermitentes e localiza dos em vales bem definidos, foram designados de primeira ordem; os segmentos de rios formados pela junção de dois canais de prí meira ordem foram classificados de segunda ordem e os formados pela junção de dois de segunda ordem, de terceira ordem e, as sim sucessivamente. Os canais de segunda ordem podem receber ou tros canais de primeira ordem e os canais de ordens mais eleva das podem receber maior número de canais de ordens inferiores. o tronco do rio através do qual passa toda a descarga da āgua e sedimentos da bacia constitui o canal de ordem mais elevada. A utilidade deste sj.stema está baseada na premissa que, se uma amostra suficientemente grande é analisada, o número de ordem dos canais é diretamente proporcional às dimensões relativas da bacia, tamanho do canal e vazão da água e descarga de sedimen tos do rio. Por este sistema, duas ou mais bacias de carenagem muito diferentes na escala linear podem ser equacionadas ou com paradas nas partes correspondentes de suas geometrias, através do uso do mesmo número de ordem, STRAHLER (1957).

Os padrões de drenagem foram classificados em dois grupos, os básicos e os modificados, PARVIS (1950). No grupo dos básicos foram descritos os modelos: dentrítico, treliça, ra dial, paralelo, anular e o retangular; e no grupo dos modifica dos foram agrupados cerca de trinta modelos. Como neste traba lho só ocorreram modelos relacionados ao dentrítico, procurou- 
-se enfatizá-1o. Este padrão constitui um padrão bem integrado e formado por um sistema de rios composto por um rio principal e por seus tributários com distribuição que se assemelha à dis posição dos ramos de uma ārvore. A sua existência implica que a área foi originalmente nivelada e constituida de materiais rela tivamente recentes, AVERY (1968) e REEVES et alii (1975).

De acordo com RAY (1963), o padrão dendrítico e o dendrítico modificado ocorrem nas áreas onde a erosão é mais ou menos uniforme, como em muitos depósitos sedimentares ou em man tos de intemperismo sobre embasamentos sem estrutura pronuncia da. GOOSEN (1968) se referiu a este sistema de drenagem afirman do que o mesmo apresenta alta visibilidade na imagem estereoscó pica.

Cada padrão apresenta as seguintes característi cas descritivas: grau de integração, densidade, grau de unifor midade, orientação, grau de controle, ângulos de junção, angula ridade e tipo ou modelo; as quais refletem condições de terre no, como o grau de erosibilidade, a uniformidade dos materiais e a existência de fatores modificadores, LUEDER (1959).

RICCI e PETRI (1965) introduziram o termo anoma lia para representar qualquer configuração que não esteja adap tada à dominante. As anomalias fornecem informações sobre as va riações da textura superficial, permeabilidade dos materiais expostos, grau de erodibilidade e condições estruturais presen tes num sistema de drenagem. 
A classificação das características do padrão de drenagem foi apresentada também por LUEDER (1959), estando de maneira geral, baseada no grau de desenvolvimento e nos aspeç tos típicos de cada característica.

\subsubsection{Caracterização quantitativa}

A caracterização quantitativa da bacia de drena gem está fundamentada na caracterização do relevo e rede de drẹ nagem.

\subsubsection{Relevo}

O princípio da análise hipsométrica foi sinteti zado por STRAHLER (1952) para o estudo de bacias hidrográficas. A análise hipsométrica expressa a relação entre a área da seção transversal plana e horizontal da bacia e a sua altura, tendo sido inicialmente desenvolvida por Langbein em 1947, LANGBEIN et alii (1947). O objetivo da análise hipsométrica é determinar a distribuição dos solos e/ou rochas na bacia, desde a sua base até o topo.

A curva hipsométrica constitui-se numa função con tínua que relaciona a altura relativa com a área relativa. A forma da curva varia com o estágio de desenvolvimento da bacia, definindo-se formas características para os estágios jovem, ma 
duro e fase de pene-planície. As propriedades da curva apresen tam tendência de não variar quando o material é homogêneo, sen do semelhantes onde ocorrem similaridade de condições climātí cas e geológicas.

Partindo da curva hipsométrica, Fredéric Founier, estabeleceu os índices coeficientes de massividade do relevo e coeficiente orográfico, CHRISTOFOLETTI (1974). O coeficiente de massividade expressa a relação entre a altura média do relevo e a área da bacia e o coeficiente orográfico expressa um valor oḅ tido pela multiplicação do valor do coeficiente de massividade pelo da altura média.

outro elemento para a caracterização do relevo é a razão de relevo. Este índice foi definido por SCHUMM como a relação entre o relevo total e o comprimento da bacia. O relevo total é identificado como sendo a diferença de eleva Ção entre a desembocadura e o topo da bacia e o comprimento to tal, corresponde ao maior alinhamento da bacia, na direção do vale principal, definido pela desembocadura e extremo oposto. De maneira geral, a razão de relevo indica a declividade média da bacia, constituindo-se num nūmero adimensional correlacioná vel com outras medidas, independentemente do tamanho da bacia, STRAHLER (1952). Este índice foi relacionado à perda anual de sedimentos, numa série de pequenas bacias de drenagem da provín cia de Plateau Colorado, sendo obtida uma regressão significa tiva, SCHUMM (1956). 


\subsubsection{Rede de drenagem}

As determinações dos índices quantitativos da re de de drenagem possibilitaram inferências sobre diversos aspec tos e não apresentam a subjetividade da caracterização descrití va, HORTON (1945).

\subsection{Padrão de drenagem}

HORTON (1945) propôs o número da ordem de ramifí cação e os indices densidade de drenagem e frequência de rios para expressar o grau de desenvolvimento da rede de drenagem.

A densidade de drenagem foi definida por Horton como o comprimento médio dos segmentos de rios por unidade de área e a frequência de rios, como o número de segmentos de rios por unidade de área. De acordo com STRAHLER (1957), a densida de de drenagem é um importante indice para representar a topo grafia de uma bacia hidrográfica. Para as mesmas condições, à medida que o valor numérico da densidade de drenagem aumenta ocorre uma diminuição proporcional das áreas das bacias de prí meira ordem. Segundo HORTON (1945), quando se consideram simul taneamente bacias pequenas e grandes, os valores da densidade e frequência de rios não são diretamente comparáveis, porque eles variam usualmente com a área de drenagem. 
RAY (1963) considerou que num determinado ambien te climático a densidade de drenagem está relacionada principal mente com a resistência à erosão dos materiais presentes. Segun do verificações de FREITAS (1952) e CHRISTOFOLETTI (1974), os valores da densidade de drenagem são maiores à medida que au menta a declividade do terreno. A densidade de drenagem quantí fica a textura do padrão de drenagem e é uma expressão da preci pitação pluviométrica e da capacidade de infiltração do solo, ZINKE (1960) e RUHE (1975). TOdavia, HORTON (1945) considerou que o padrão de drenagem e a densidade, separados ou combinados, não são suficientes para uma caracterização perfeita da rede de drenagem, em razão de: 1) os mesmos comprimentos e números de rios podem existir em padrõas diferentes; 2) várias combinações de.ordens, números e comprimentos de rios podem resultar valo res muito próximos da densidade e, 3) podem existir tipos seme lhantes de padrões com densidades diferentes. Contudo, STRAHLER (1957), considerou a densidade de drenagem como o parâmetro mais importante na análise das formas da terra.

A textura topográfica foi inicialmente proposta com o objetivo de identificar o tamanho médio das unidades com ponentes do relevo, sendo designada por SMITH (1950), nas clas ses grosseira, média e fina.

A razão de textura é resultante da relação entre - número de crênulas de uma curva de nível escolhida num mapa topográfico e o perímetro da bacia a que a curva se refere, 
SMITH (1950). De acordo com STRAHLER (1957) esse índice constí tui uma medida da compacidade da bacia e se correlaciona com a densidade de drenagem. Com o propósito de determinar a razão de textura a partir de estudos realizados sobre fotografias aéreas, FRANÇA (1968) substituiu o número de crênulas da curva de nível pelo número total de segmentos de rios da bacia, baseando-se no fato que os sistemas hidrográficos podem ser melhor estudados em mapas básicos de drenagem obtidos pelo exame estereoscópico de imagens aéreas.

O Indice extensão do percurso superficial repre senta a distância média percorrida pelas enxurradas desde 0 in terflúvio até o canal permanente, tendo sido denominado in cialmente por HORTON (1945) de comprimento do fluxo superficial. Este índice é considerado como uma das mais importantes variá veis que afetam o desenvolvimento hidrológico e fisiográfico da bacia de drenagem, CHRISTOFOLETTI (1974).

Outro índice de grande importância no estudo do padrão de drenagem é o coeficiente de manutenção, definido por SCHUMM (1956) como a área minnima necessária para a manutenção de um metro de canal de escoamento. Este índice, como no caso anterior, apresenta alto significado no desenvolvimento hidro lógico e fisiográfico da bacia. . 
3.3.4.2.2. Composição da rede de dreną gem

A expressão composição da rede de drenagem foi proposta para indicar os números e os comprimentos de rios das diferentes ordens, independentemente do padrão. A composição tem alto grau de significação hidrológica, enquanto que o pa drão isolado tem pouca ou nenhuma significação, HORTON (1945).

Smith em 1953, verificou que existe uma relação entre o número de rios de cada ordem (Nw) e a respectiva ordem (w), na forma $\mathrm{Nw}=\mathrm{a} \cdot \mathrm{w}^{-\mathrm{b}}$, STRAHLER (1957). Contudo, MAXWELL (1955), ao relacionar o logarítmo do número de rios com as res pectivas ordens de ramificação obteve uma reprodução gráfica em linha reta, com muito pequeno espalhamento dos dados, expressan do-a na forma $\log \mathrm{Nw}=\log \mathrm{a}-\mathrm{w} \cdot \log \mathrm{b}$, divergindo portanto, da verificação de Smith.

A razão da ramificação foi enunciada como a rela ção entre os números de rios de duas ordens consecutivas, HOR TON (1945), sendo considerada por STRAHLER (1957) como um valor que expressa a forma do sistema de drenagem. Este valor apresen tou-se altamente estavel, revelando pequenas variações mesmo quando se comparavam regiões e ambientes diferentes, exceto pa ra regiões onde ocorria efeito dominante do controle geológico. MAXWELL (1955) adotou o valor do anti-logarítmo de b, da sua ex pressão, como o valor da razão de ramificação (Rb) . 
STRAHLER (1957) relacionou os logarítmos dos com primentos totais dos rios de cada ordem às respectivas ordens, verificando que seus dados se ajustavam melhor à expressão Ion Iw $=$ $=\log \mathrm{a}-\mathrm{b} \cdot \log \mathrm{w}$, onde $\mathrm{Lw}=$ comprimento total de segmen tos de rios de cada ordem e $w=$ número da ordem. Enquanto que FRANÇA (1968) constatou um melhor ajustamento à expressão Log Iw $=$ $=\log a-w \cdot \log b .0$ valor $b$ da regressão permite inferir sobre as diferenças observadas na variação do comprimento de ca nais com a mudança da ordem, desde que as bacias apresentem sí milaridade geométrica, STRAHLER (1957).

A razão de comprimentos totais foi estabelecida pela relação entre os comprimentos totais dos segmentos de rios de uma ordem (lw) e os da ordem imediatamente inferior. FRANÇA (1968) propôs a expressão $\mathrm{Rlw}=$ antilog b para representar a ra zão de comprimentos totais.

VASQUES FILHO (1972) relacionou os comprimentos médios de cada ordem ( $\mathrm{Lm}$ ) às respectivas ordens, verificando que os seus dados se ajustaram melhor a uma relação na forma $\mathrm{Lm}=\mathrm{a} \cdot \mathrm{b}^{-\mathrm{w}}$.

A razão de comprimentos médios foi estabelecida por HORTON (1945) como a relação entre os comprimentos médios dos segmentos de rios de uma dada ordem e os da ordem imediata mente inferior e VASQUES FILHO (1972) propôs para sua caracte rização a expressão $\mathrm{Rl}=$ antilog $\mathrm{b}$.

STRAHLER (1957) verificou que havia uma relação 
inversa entre os valores de comprimentos médios de rios e os va lores da densidade de drenagem, ao constatar que com o aumento do valor da densidade de drenagem ocorria uma diminuição quase que porporcional dos tamanhos dos componentes fluviais das ba cias de drenagem, resultados estes suportados pelo trabalho de CHRISTOFOLETTI e CESAR (1978), que observaram, ainda, uma menor significância dessa relação com o aumento do número de ordem das bacias.

FRANÇA (1968) propôs a expressão $\mathrm{Rlw}=\mathrm{Rb} \cdot \mathrm{Rlm}^{-1}$ para o cálculo da razão de comprimentos totais (Rlw), razão de bifurcação ( $R b)$ e razão de comprimentos médios (Rlm).

3.3.5. Critérios de amostragem para o estudo da rede de drenagem

Os estudos de HORTON (1945) consideravam cada ba cia de drenagem uma amostra e este critério foi utilizado suces sivamente pelos pesquisadores que o sucederam.

Em 1960 foi apresentado o critério de amostras cir culares para ser empregado no estudo de redes de drenagem para fins de caracterização litológica, sendo adotadas amostras com tamanho equivalente a uma área de $10 \mathrm{~km}{ }^{2}$, RAY e FISCHER (1960). Segundo BURINGH (1960), as amostras circulares podem apresentar variação de tamanho equivalente a uma amplitude de 10 a $100 \mathrm{~km}^{2}$. Nos estudos de solos, FRANÇA (1968) comparou os 
dois critérios de amostragem, encontrando resultados que indica ram uma melhor adequabilidade das amostras circulares. Este au tor utilizou círculos de tamanho equivalente a $10 \mathrm{~km}^{2}$ de área. Os resultados de França foram suportados pelos trabalhos de MAR CHETTI (1969), FADEL (1972), VASQUES FILHO (1972), GEVAERD (1974), GARCIA (1975), KOFFLER (1976), FREIRE (1977) e CARVALHO (1977). Com respeito à variação do tamanho das amostras, os trabalhos de SOUZA (1975), KOFFLER (1976) e FREIRE (1977) permitiram constatar que a utilização de círculos com tamanho equivalente a $5 \mathrm{~km}^{2}$ de área propiciaram uma melhor representa ção dos solos nos casos em que a conformação da área de ocorrên cia limita a tomada de amostras de maior tamanho. 
4. MATERIAIS E METODOS

Os materiais e a metodologia empregados na reali zação do presente estudo são apresentados em seguida.

\subsection{Materiais}

As bacias hidrográficas e as redes de drenagem das áreas de ocorrência das unidades de solos que serviram de base para o estudo, constituiram o material básico do presente trabalho.

4.1.1. Descrição geral das áreas

As duas āreas selecionadas representam as ocorrên cias de duas unidades de mapeamento: Solos Podzolizados de Lins e Marília - var. Marília (Pml) e Solos Podzólico Vermelho-Ama relo - var. Laras, classificadas segundo a COMISSÃO DE SOLOS (1960a). Essas áreas estão localizadas, respectivamente, na re 
gião de Jaboticabal, no planalto ocidental paulista e na região de Piracicaba, na depressão periférica paulista. Apresentam co mo características comuns o mesmo tipo climático e a presença de horizonte B textural nos perfis de solo.

\subsubsection{Area representativa da unidade Solos Podzolizados de Lins e Marília - var. Marilia}

A situação geográfica é definida pelas coordena das, latitudes $21^{\circ} 10^{\prime}$ e $21^{\circ} 15^{\prime}$ s e longitudes, $48^{\circ} 25^{\prime}$ e $48^{\circ} 2$ J. $^{\prime} \mathrm{W}$. Gr. Está localizada na parte centro-norte do Estado de são Pau lo, no planalto ocidental paulista e ocupa porções dos municí pios de Jaboticabal, Monte Alto e Taiúva. A figura l mostra a sua posição no Estado de são Paulo e em relação à outra área de estudo.

A conformação topográfica é a de planalto colino so, subtabular, situaảo no reverso da cuesta de Monte Alto, apre sentando relevo ondulado com interflúvios planos, sendo comum a ocorrência de linhas de ruptura de declives. Ocupa a faixa alti métrica de aproximadamente 530 a 700 metros. A sua superfície, de modo geral, mergulha 1 a 2 graus para o noroeste, excetuando os declives locais em direção à drenagem regional, PENTEADO e RANZANI (1971).

O clima foi classificado como Cwa, segundo a clas 


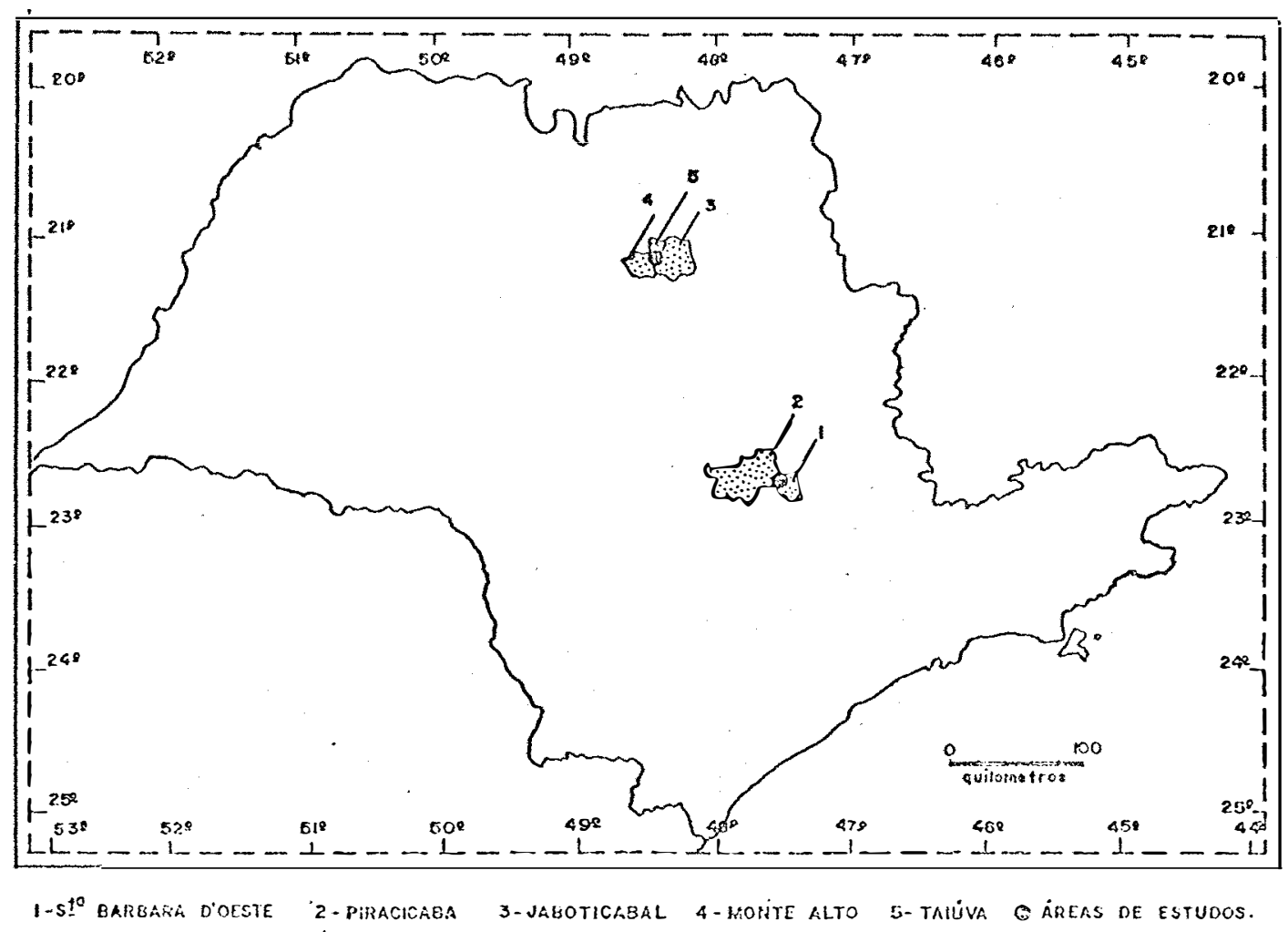

Figura 1 - Localizações das Āreas de Estudo no Estado São Paulo.

sificação de köeppen descrita em VILLA NOVA e SANTOS (1966)， sendo denominado clima mesotérmico de inverno seco, em que a temperatura do mês mais quente é superior a $22^{\circ} \mathrm{C}$ e a do mês mais frio é inferior a $18^{\circ} \mathrm{C}$. A precipitação anual é de aproximą damente $1280 \mathrm{~mm}$, com distribuição anual mostrando concentração no período outubro-março e relativa seca no período abril-setem bro.

No quadro 1 são apresentados os dados climáticos 


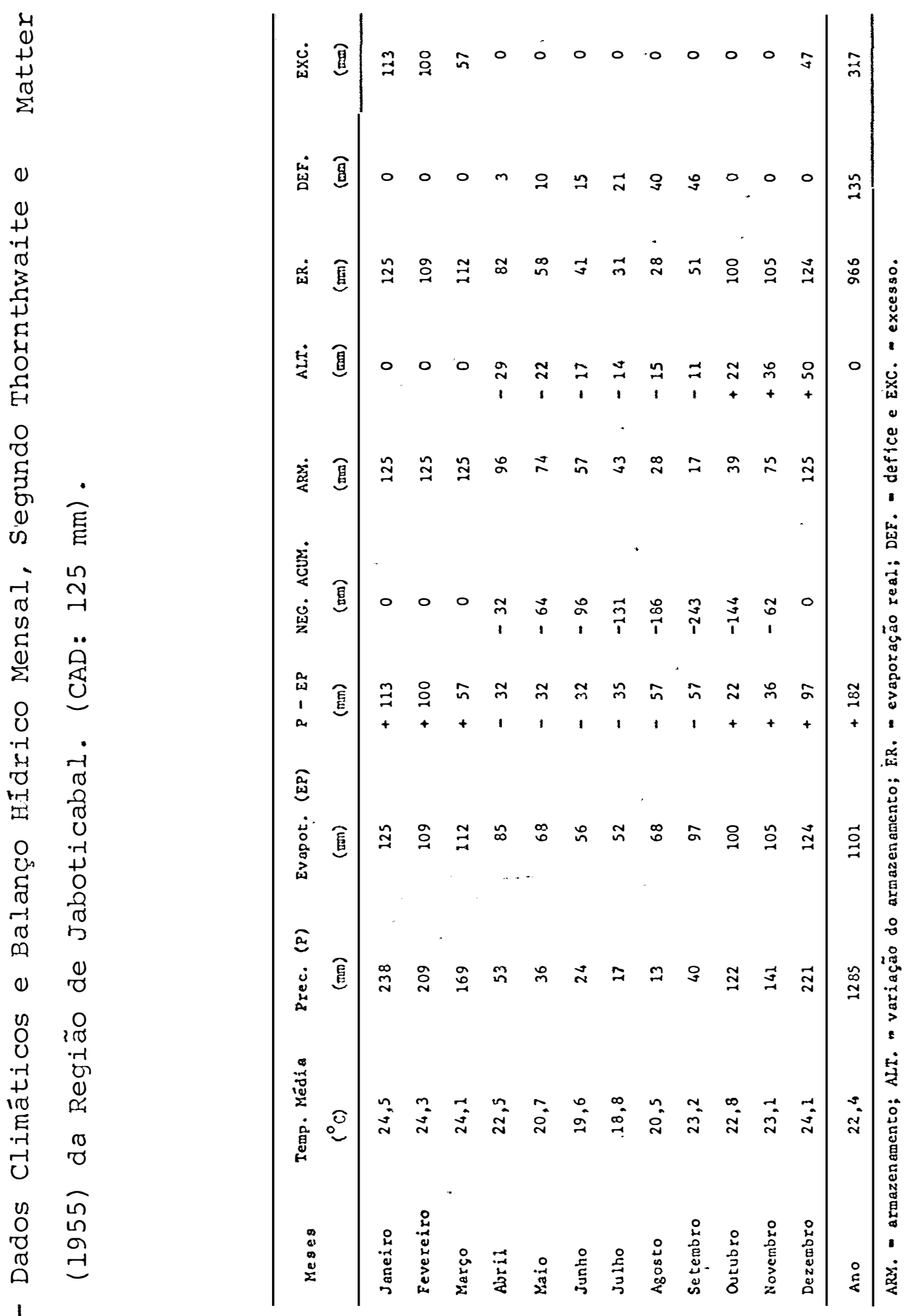

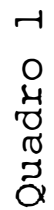


temperatura e precipitação, em termos de médias mensais referen tes ao período de 15 anos, fornecidos pela FCAV "Campus" de Ja boticabal e o balanço hídrico segundo Thornthwaite e Matter (1955), elaborado conforme BURGOS e VIDAL (1951), da região de Jaboticabal.

o gráfico representativo do balanço hídrico men sal é apresentado na figura 2 .

Nas condições climáticas atuais ocorre na região de Jaboticabal um período de excedentes de água, com valor acu mulado de $317 \mathrm{~mm}$, o qual inicia em dezembro e termina em março; um período de armazenamento, com valor acumulado de $108 \mathrm{~mm}$, que inicia no final de outubro e encerra em dezembro; um período de retirada de água do solo, com valor acumulado de $108 \mathrm{~mm}$, que cọ meça em março e termina em setembro e um período de défices, com valor acumulado de $135 \mathrm{~mm}$, que ocorre concomitantemente com o de retirada de água do solo.

O material geológico foi identificado como areni to Bauru - fácies conglomerática, de textura variando desde a arenosa até a argilosa e de cor rósea marchetada de branco, PEN TEADO e RANZANI (1971). Segundo a classificação do Instituto Geográfico e Geológico, SÃO PAULO (1963), esse material é enqua dra na formação Bauru, pertencente ao período cretáceo, era mesozóica.

Essa unidae litológica da formação Bauru è a úni ca que possui expressão em termos de área, ocorrendo em todo o 


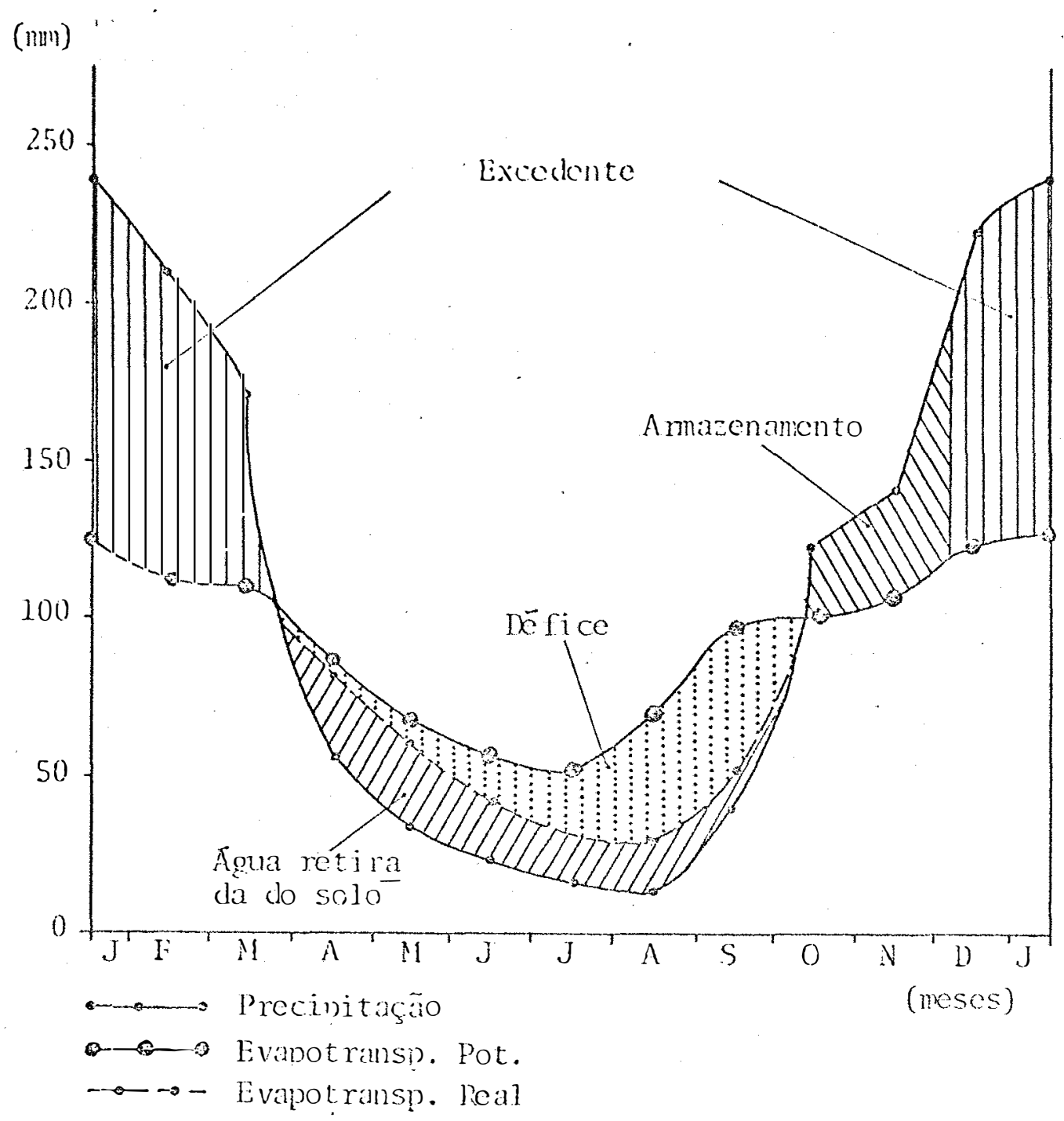

Figura 2 - Balanço Hídrico Mensal da Região de Jaboticabal.

planalto noroeste do Estado de São Paulo e podendo se apresen tar como arenito consolidado ou não consolidado, mas sempre com a presença de cimento calcário. Está situada na província geo mórfica V - planalto ocidental, ALMEIDA (1964). A área de estú do está localizada bem próxima dos limites com a província geo 
morfológica IV - cuestas basálticas.

A formação vegetal originária foi classificada co mo floresta fluvial estacional, JOLY (1970) e como floresta la tifoliada tropical, COMISSÃO DE SOLOS (1960a). Essa vegetação foi substituida por formações vegetais culturais como a cana-de -açúcar, citrus e diversas culturas de ciclo anual e por pasta gens e formações naturais secundárias.

\subsubsection{2. Ārea representativa da unidade Solos Podzólico Vermelho-Amarelo - var. Laras}

A situação geográfica é definida pelas coordena das, latitudes $24^{\circ} 41^{\prime}$ e $22^{\circ} 47^{\prime} \mathrm{s}$ e longitudes $47^{\circ} 28^{\prime}$ e $47^{\circ} 31^{\prime} w$. Gr: Está localizada na zona do médio Tietê, ocupando partes dos municípios de Piracicaba e Santa Bárbara D'Oeste. A figura 1 mostra a sua posição no Estado de são Paulo e em relação à ou tra área de estudo.

A conformação topográfica é a de relevo tabular, ondulado, com interflúvios planos ou suavemente ondulados, sen do comum a presença de linhas de ruptura de declives. Ocupa fai ca altimétrica de 500 a 600 metros, sendo considerada como área de altitudes baixas em relação às do embasamento cristalino e Grupo São Bento, PENTEAdo (1968).

O clima apresenta a mesma classificação da área anteriormente descrita. A precipitação anual é de aproximadamen 
te $1230 \mathrm{~mm}$, com distribuição que define um período de chuvas de 6 meses, ocorrendo de outubro a março e outro de relativa se ca, com duração de 6 meses, que inicia em abril e termina em se tembro.

No quadro 2 são apresentados os dados climáticos temperatura e precipitação, em termos de médias mensais referen tes a um período de 15 anos, fornecidos pela ESALQ/USP, os de evapotranspiração potencial mensal e o balanço híarico de Thorn thwaite e Matter (1955) da região de Piracicaba.

O gráfico representativo do balanço hídrico men sal é apresentado na figura 3 .

Nas condições climāticas atuais ocorre na região de Piracicaba um período de excedentes de água, com valor acumu lado de $238 \mathrm{~mm}$, que inicia em dezembro e termina em março; um período de armazenamento, com valor acumulado de $75 \mathrm{~mm}$, que ini cia em setembro e termina em novembro; um período de retirada de água do solo, com valor acumulado de $65 \mathrm{~mm}$, ocorrente desde março até outubro e um período de défices, com valor acumulado de $27 \mathrm{~mm}$, que inicia em junho e termina em outubro.

O material geológico foi identificado por RANZA NI et alii (1966) como arenitos do Grupo Tubarão, formações Ita petininga e Tietê. Os arenitos dè formação Itapetininga são os do membro Tupi. Essas formações são enquadradas no período car bonífero da era paleozóica, SÃO PAULO (1963). Os arenitos do membro Tupi apresentam-se associados a siltitos argilosos, com 


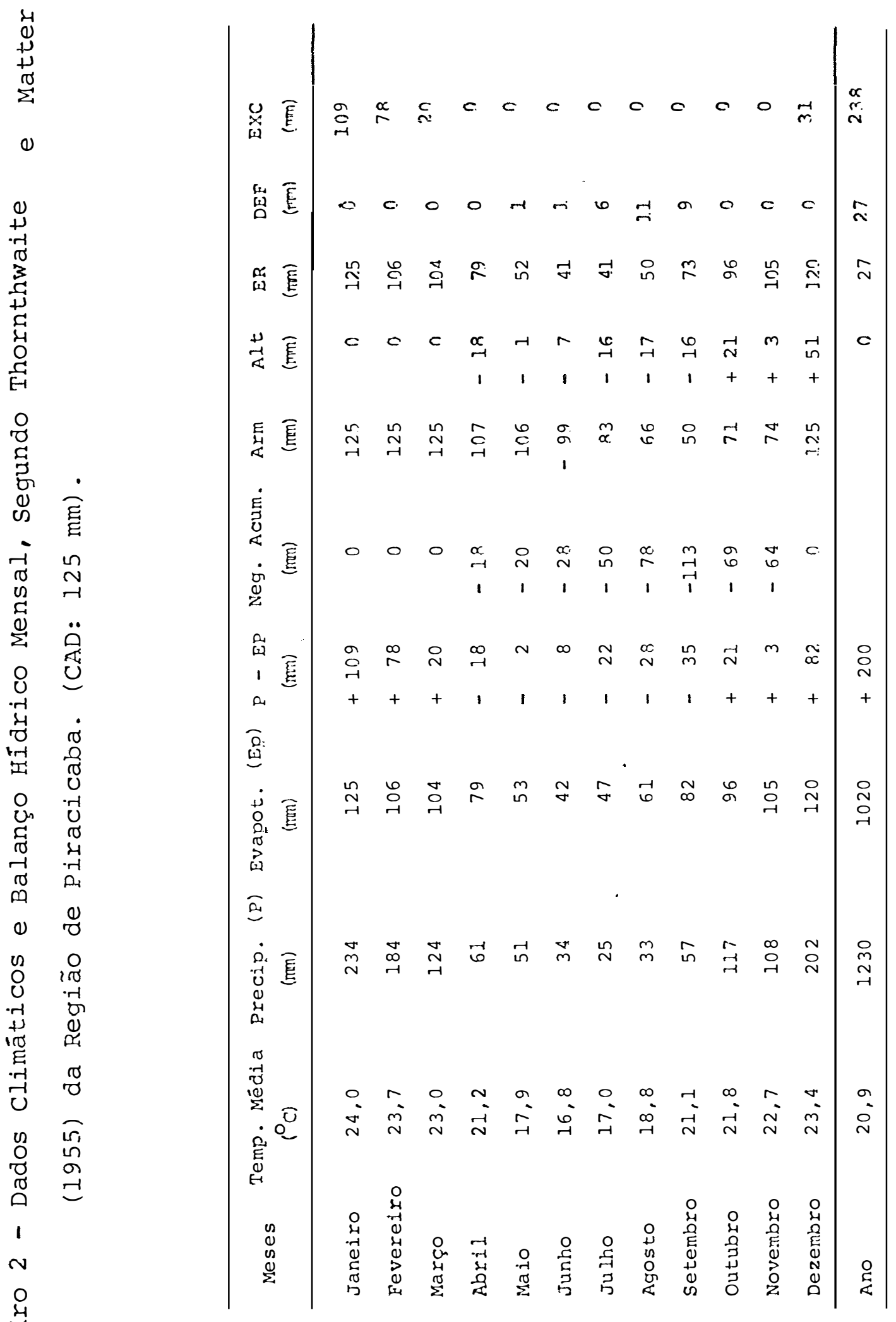




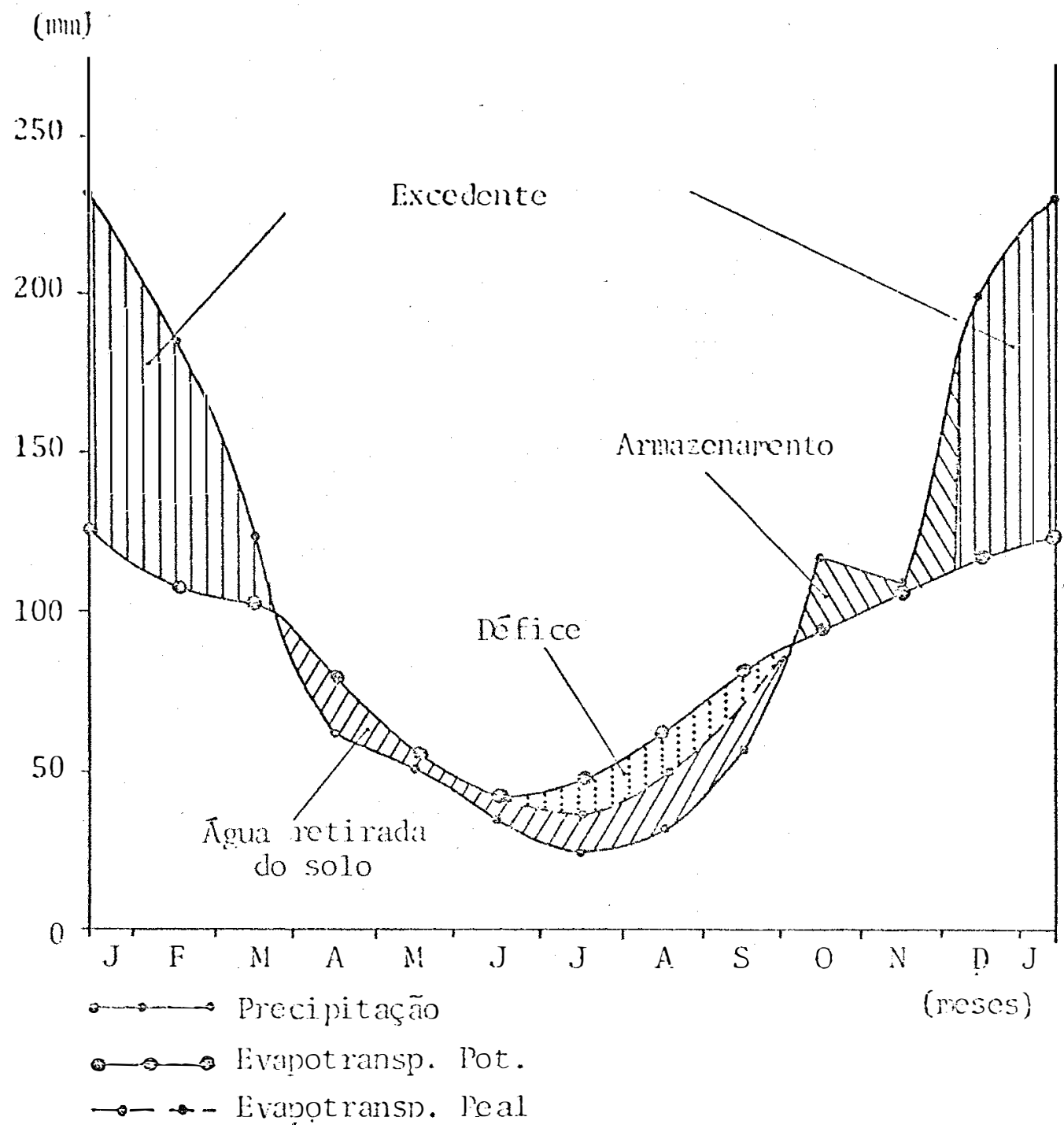

Figura 3 - Balanço Hídrico Mensal da Região de Piracicaba.

frequente estratificação cruzada e possuem como cor predominante a chocolate. Os arenitos da formação Tietê apresentam-se asso ciados, em rápida sucessão, com siltitos e folhelhos, possuindo cores claras. Segundo PENTEADO (1968) essas formações apresen 
tam estrutura homoclinal, cujas camadas mergulham numa direção geral noroeste, com inclinação de 15 a 20 metros por quilôme tro. Estas unidades litológicas estão situadas na província geo morofológica III, zona do médio Tietê, ALMEIDA (1964).

A formação vegetal origināria foi classificada co mo floresta fluvial estacional tropical, JOLY (1970), sendo substituida por mata talhada, pastagem, reflorestamento e cultu ra da cana-de-açúcar.

\subsubsection{Descrição das unidades de solos}

As unidades de solos foram classificadas à nível de variação de grande grupo como Solos podzolizados de Lins e Marília - var. Marília (Pml) e Solos Pódzólicc Vermelho-Amare lo - var. Laras (PVls), COMISSÄO DE SOLOS (1960a). As duas uni dades apresentam as características gerais dos Solos Podzólicos Vermelho-Amarelos excetuando na primeira unidade a saturação de bases que é alta. Os solos da primeira unidade foram classifica dos mais recentemente como Solos Podzólico Vermelho-Amarelo -

- Eutrófico, DEpartamento NACIONAL DE PESQUisa AgRopecuáRIA (1971). Essas unidades apresentam nas áreas selecionadas dife renças de comportamento hidrológico, sugeridas pelas condições de drenagem dos perfis.

As características principais, na ărea selecionada, da unidade Solos Podzolizados de Lins e Marília - var. Marília 
são, de acordo com ALOISI (1973) e MAZZA (1979), as seguintes: provavel material de origem - arenito Bauru com cimento calcá rio; relevo - forte ondulado; drenagem do perfil - boa, sendo excessiva no horizonte $A$; sequencia de horizontes - $A p, A_{3}, B_{2}{ }^{\prime}$ $\mathrm{B}_{22}, \mathrm{~B}_{3}$ e C; profundidade - superior a $170 \mathrm{~cm}$; textura do hor $\underline{\underline{i}}$ zonte superficial - areia barrenta fina; textura do horizonte B - barro argilo-arenoso; estrutura do horizonte superficial - maciça; estrutura do horizonte B - composta (prismática e em blocos), moderada e pequena a média; consistência do horizonte superficial - macio, friável, ligeiramente plástico e ligeira mente pegajoso; consistência do horizonte B - ligeiramente duro e duro, friável, plástico e pegajoso; transição entre os hori zontes A e B - abrupta; capācidade de retenção da água no per fil. - média; bases trocáveis, capacidade de troca catiônica e saturação de bases, no horizonte superficial, respectivamente, $4,33 \mathrm{e} . \mathrm{mg} / 100 \mathrm{~g}$ de solo, 6,79 e. $\mathrm{mg} / 1.00 \mathrm{~g}$ de solo e 63,80; e bases trocáveis, capacidade de troca catiônica e saturação de bases no horizonte B, respectivamente, variando de 5,35 a 7,74 e. $\mathrm{mg} / 100 \mathrm{~g}$ de solo, 7.45 a $10,92 \mathrm{e} . \mathrm{mg} / 100 \mathrm{~g}$ de solo e $70,8 \mathrm{a}$ $74,2 \%$. Os Litossolos associados à unidade ocupam aproximadamen te 15 a $20 \%$ da área global, estando localizados, principalmente, nas posições das linhas de ruptura de declives. A erosão se ma nifesta pela erosão laminar moderada, erosão em sulcos médios e frequentes e voçorocas localizadas principalmente junto à rede de escoadouros. 
A classificação, de acordo com o Soil survey Staff de 1970, é Tropudalf, fine loam, isothermic, siliceous e nona cid, ALOISI (1973).

As características, na ărea selecionada, da unidạ de Solos Podzólicc Vermelho-Amarelo - var. Laras (PVls) foram descritas por RANZANI et alii (1965), sendo os solos agrupados em duas séries, a Quebra-Dente e a Tijuco Preto.

As características principais da Série Quebra- Den te são: provável material de origem - arenito glacial de cores claras da formação Tietê; relevo - ondulado a forte ondulado, irregular a médio; drenagem do perfil - moderada, sendo exces siva no horizonte $A$; sequência de horizontes - $A p, A_{12}, A_{2}, A_{3} /$ $/ \mathrm{B}_{1}, \mathrm{~B}_{21}, \mathrm{~B}_{22}, \mathrm{~B}_{3} / \mathrm{C}$ e $\mathrm{Ccn}$; profundidade - superior a $225 \mathrm{~cm}$; textura do horizonte superficial - areia barrenta fina; textura do horizonte B - barro arenoso fino; estrutura do horizonte su perficial - grãos simples; estrutura do horizonte B - blocos subangulares, moderada a forte e média; consistêncịa do horizon te superficial - macio, solto, não plástico e não pegajoso; consistência do horizonte B - duro, firme, ligeiramente plásti co e ligeiramente pegajoso; transição entre os horizontes A e B, - abrupta; bases trocáveis, capacidade de troca catiônica e saturação de bases do horizonte superficial - respectivamente 3,43 e. $\mathrm{mg} / 100 \mathrm{~g}$ de solo, 5,88 e. $\mathrm{mg} / 100 \mathrm{~g}$ de solo e 58,3\%; e bases trocáveis, capacidade de troca catiônica e saturação de bases do horizonte B - variando, respectivamente, de 1,51 
2,65 e. $\mathrm{mg} / 100 \mathrm{~g}$ de solo, 3,20 a 4,06 e. $\mathrm{mg} / 100 \mathrm{~g}$ de solo e 47,2 a $60,3 \%$. Os Litossolos associados à unidade ocupam ap̣roxi madamente 25\% da área global.

As características principais da Série Tijuco Preto são: provavel material de origem - arenito glacial de cor chocolate, membro Tupi; relevo - ondulado; drena gem do perfil - moderada, sendo excessiva no horizonte super ficial; sequência de horizontes $-A_{1}, A_{2}, A_{3} / B_{1}, B_{2}, B_{3} / C$ e $C$; profundidade - superior a $175 \mathrm{~cm}$; textura do horizonte super ficial - barro arenoso; textura do horizonte B - barro areno so; estrutura do horizonte superficial - granular, média e fra ca; estrutura do horizonte B - blocos subangulares, moderada e grande; consistência do horizonte superficial - macio, muito friável, não plástico e não pegajoso; consistência do horizon te B - ligeiramente duro, friável, plástico e pegajoso; transi ção entre os horizontes A e B - clara; bases trocáveis, cabaci dade de troca catiônica e saturação de bases do horizonte su perficial - respectivamente, 4,63 e. $\mathrm{mg} / 100 \mathrm{~g}$ de solo, 7,49 e. $\mathrm{mg} / 100 \mathrm{a}$ de solo e 64,4\%; e bases trocáveis, capacidade de troca catiônica e saturação de bases do horizonte B - respectivamente, 1,74 e. ma/100 a de solo, 4,42 e. mg/100 g de solo e 34,9\%. Nesta série há a ocor rência de fase rasa associada a Litossolos. A erosão se mani festa pela erosão laminar moderada e severa e em sulcos médios e profundos, frequentes.

A classificaçáo, de acordo com o sistema $7^{a}$ aroro 
ximação, é respectivamente, Ochrultic Typustalf e Umbric Typo chrult, RANZANI et alii (1966).

\subsubsection{Imagens aëreas}

As imagens aéreas utilizaảas constam de colecões de fotografias aéreas verticais, fotomosaicos e fotoíndices.

As fotografias aéreas, referentes às duas āreas de estudo, são pancromáticas, preto-e-branco e verticais. A es cala aproximada é 1:25.000. Estas fotografias fazem oarte da coleção da cobertura aerofotográfica do Estado de são Paulo, realizada nos anos 1971/1972, sob o patrocínio do Instituto Brasileiro do Café. O conjunto de fotografias é composto de pa reś estereoscópicos, apresentando recobrimentos lonqitudinais e laterais de, respectivamente, 60 e $30 \%$.

Os fotomosaicos são formados por montagens das fotografias aéreas, onde foram eliminados os recobrimentos. Os fotomosaicos são do tipo semicontrolado.

Os fotoíndices são reproduções, na escala aproxi mada 1:100.000, de uma montagem dessas fotografias, onde se destacaram os seus números de identificação.

4.1.4. Cartas topográficas

As cartas topográficas utilizadas foram as per 
tencentes à Coleção Carta do Brasil, editada pela Fundação Ins tituto Brasileiro de Geografia. Apresentam escala 1:50.000 e equidistância vertical entre curvas de nível de 20 metros. As folhas empregadas foram as de Jaboticabal, Pirangi, Piracicaba, Limeira, Capivari e Americana.

\subsubsection{Cartas de solos}

As cartas de solos utilizadas foram a Carta de Solos do Estado de São Paulo, COMISSÃO DE SOLOS (1960b), a Car ta de Solos da Região Noroeste do Município de Jaboticabal, MAZ ZA (1979) e a Carta de Solos do Município de Piracicaba, RANZANI et alii (1966).

\subsubsection{Equipamento}

Como equipamento básico foram empregados estere oscópios de espelho, marca Zeiss, modelo N2: estereoscópios de bolso, marca Vasconcellos; altímetro com escala graduada de dois em dois metros, marca Paullin e altímetros com escala graduada de 10 em 10 metros, marca Thomman.

Como equipamento auxiliar foram empreqados cur vímetros, escala triangular, planímetro, pantógrafo e material de desenho. 
4.2. Métodos

4.2.1. Seleção das āreas

As áreas de estudo foram selecionadas após a fi xação dos solos que serviriam de base para o trabalho, tendo sido aplicado como critério preferencial, a escolha de pelo me nos uma área na região de Jaboticabal.

Para a identificação e delimitação das áreas fọ ram utilizadas as cartas de solos e topográficas, os fotomosai cos e as fotografias aéreas. Foram realizadas, concomitantemen te, visitas de campo.

4.2.2. Delimitação das áreas nas imag̣ens fotográficas

A delimitação das āreas nas. imagens fotooráficas foi efetuada mediante exame estereoscópico, adotando-se a meto dologia descrita em RABBEN (1960).

4.2.3. Elaboração dos mapas bāsicos

Os mapas básicos fọram elaborados na mesma esca la das fotografias aéreas, empregando um sistema de montagens de moldes transparentes baseado na triangulação radial, confor me LOPES VERGARA (1971). 
Os mapas da drenagem superficial foram obtidos pela transferência das redes desenhadas nos moldes transparen tes para os mapas básicos.

O desenho das redes de drenaqem e da delimitação das bacias hidrográficas foi realizado nelo decalgave do traçado determina do pelo exame estereoscópico das imagens aéreas. Nesta opera ção, foi considerada como área útil das fotografias a área de terminada em função do par alternado. O traçado das redes de drenagem incluiu todos os canais visíveis na imagem fotouráfi ca, sendo considerados os cursos d'água permanentes e temborá rios, adotando-se as sugestões de STRAHLER (1957), LUJEDER (1959) e RAY (1963).

As bacias delimitadas foram as de terceira ordem, de acordo com o sistema de Horton modificado por STRAHLEP (1957).

4.2.4. Seleção das bacias hidrográficas

Em cada área de estudo foram escolhidas auatro bacias hidrográficas da mesma ordem de ramificação e que aten điam ao critério de semelhança geométrica preconizada por STRAHLER (1957) . 
4.2.5. Seleção das amostras circulares

Em cada área de estudo foram escolhidas quatro amostras circulares de tamanho equivalente à área de $5 \mathrm{~km}^{2}$, se gundo RAY e FISCHER (1960) e SOUZA (1975). O tamanho da amos tra circular foi adotada em função de uma melhor adequação dos círculos à conformação das áreas de ocorrência dos solos.

4.2.6. Análise das bacias hidrográficas e amostras cie culares

A análise realizada foi baseada em procedimentos constantes em FRANÇA (1968), MARCHETTI (1969) e CHRISTOFOLETTI (1974). O mëtodo de fotointerpretação empregado foi o da anā lise dos elementos, descrito em BURINGH (1960).

4.2.7. Caracterização das bacias hidrogrä́ficas

As bacias hidrográficas foram caracterizadas pe las determinações relacionadas em seguida.

\section{Localização e representatividade}

A localização das bacias hidrográficas foi iden tificada em função de suas posições em relação à região que pertencem e à posição ocupada na rede de drenagem.

A representatividade da bacia em termos de ocor 
rência de solos foi estimada considerando-se a proporção da área ocupada pela unidade principal de ocorrência.

\section{Semelhança geométrica}

A semelhança geométrica existente entre as bacias representativas da mesma unidade de solo foi avaliada estabele cendo-se as razões entre os elementos das análises linear e areal, seguindo-se os critérios fixados por STRAHLER (1957).

\section{Características não dimensionais}

Como características não dimensionais das bacias foram consideradas a forma aproximada, a simetria das verten tes e o número da ordem de ramificação.

A forma aproximada foi inferida baseando-se na conformação da bacia apresentada pelo mapa de drenagem, sendo designada pela figura geométrica de maior semelhança.

A simetria das vertentes foi estabelecida median te a identificação da extensão da dissecação da superfície da bacia em relação ao vale principal.

A ordem da bacia foi designada segundo o sistema de Horton modificado por STRAHLER (1957), sendo fixado como o número de ordem da bacia do rio principal nela contido.

\section{Caracteristicas dimensionais}

Como características dimensionais foram conside rados os parâmetros determinados pelas análises linear, areal 
e hipsométrica.

As característiças determinadas pelas análises linear e areal são relacionadas em seguida.

\section{Maior comprimento}

o maior comprimento foi determinado medindo-se o alinhamento definido pelos pontos da foz do escoadouro princi pal e do extremo da bacia, situado na linha divisória, acomp̣a nhando-se a direção do vale principal. Foi empregada a escala triangular e a unidade foi expressa em quilômetro.

\section{Maior largura}

A maior largura foi determinada pela medida do alinhamento perpendicular à direção do vale principal, definí do pelos dois pontos mais distantes situados na linha divisó ria. Foi empregada a escala triangular e a unidade foi expres sa em quilômetro.

\section{Comprimento do rio principal}

o comprimento do rio principal foi determinado medindo-se o curso do rio principal. Foi empregado o curvíme tro e a unidade foi expressa em quilômetro.

\section{Comprimento da rede de drenagem}

O comprimento da rede de drenagem foi determina do pela quantificação da extensão do conjunto de canais escoa douros da bacia. Foi empregado o curvímetro e a unidade foi 
expressa em quilômetro.

\section{perímetro}

O perímetro foi determinado medindo-se a exten são da linha divisōria que delimita a bacia. Foi empreqado o curvímetro e a unidade foi expressa em quilômetro.

\section{Ârea}

A área da bacia foi determinada pela medida da extensão de sua superfície. Foi empregado o planímetro e a uni dade foi expressa em quilômetro quadrado.

\section{$\underline{\text { Forma }}$}

A forma foi determinada pelo estabelecimento dos valores dos índices de circularidade e compacidade.

O índice de circularidade é expresso pela rela ção entre a área da bacia e a área de um círculo que apresente o mesmo perímetro da bacia. Por essa relação, o valor do índi ce varia de próximo de zero à um, dando uma idéia aproximada da forma da bacia pelo afastamento de sua forma em relação ao círculo, revelada pelo afastamento do valor obtido em relação ao valor um. O índice de compacidade é obtido pela relação en tre o perímetro da bacia e o perímetro de um círculo de iqual área, CHRISTOFOLETTI (1974).

As características determinadas pela análise hị sométrica são relacionadas em seguida. 


\section{Curva hipsométrica}

A curva hipsométrica de cada bacia foi obtida a partir de mapas topográficos, seguindo-se os procedimentos de STRAHLER (1952). Foram determinadas as āreas referentes aos in tervalos de altura definidos pelas curvas de nível e amplitude altimétrica da bacia. Para a construção da curva foi adotado o critério da escala proporcional. A curva hipsométrica mostra, em proporção, o volume de material ainda existente na porção territorial de cada bacia, definido pelo espaço delimitado pe la curva e as linhas inferior e lateral esquerda do quadrado.

\section{Integral hipsométrica}

O valor da integral hipsométrica representa, em proporção, o volume ainda existente de material, considerado em relação ao volume inicial e ideal da referida porção terri torial, representado por toda a extensão do quadrado.

\section{Amplitude altimétrica}

A amplitude altimétrica foi determinada pela di ferença entre os pontos de mínima e máxima cotas da bacia. A amplitude altimétrica foi estabelecida por dados determinados diretamente no campo.

\section{$\underline{\text { Razão de relevo }}$}

A razão de relevo expressa a relação entre a am plitude altimétrica e o maior comprimento da bacia, SCHUMM 


\section{Altura média}

A altura média da bacia foi calculada pela expres são: altura média $=(1 / 100) \times$ (amplitude altimétrica $\times$ valor da integral hipsométrica), CHRISTOFOLETTI (1974).

\section{Coeficiente de massividade}

O coeficiente de massividade foi obtido pela re lação entre a altura média e a área da bacia, CHRIsTOFOLETTI (1974), sendo no presente trabalho adotada a relação $\mathrm{m} / \mathrm{km}^{2}$.

\section{Coeficiente orográfico}

O coeficiente orográfico foi obtido pela expres são: coeficiente orográfico = altura média $\times$ coeficiente de massividade, onde o coeficiente de massividade foi calculado em função da representação gráfica proporcional, conforme CHRIS TOFOLETTI ( 1974).

4.2.8. Caracterização das redes de drenagem

A caracterização das redes de drenagem foi efe tuada pela caracterização do padrão e composição da rede.

4.2.8.1. padrão de drenagem

o padrão foi caracterizado determinando-se suas caracteristicas descritivas e quantitativas. 
Como características descritivas foram determina dos o tipo ou modelo do padrão, de acordo com PARVIS (1950) e o grau de integração, densidade, grau de uniformidade, orientą ção, grau de controle, ângulos de junção, angularidade e anoma lias, de acordo com LUEDER (1959) e RICCI e PETRI (1965). O en quadramento dessas características em categorias obedeceu ao constante no quadro 3 .

Quadro 3 - Características Descritivas do Padrão de Drenagem e Respectivas Categorias, LUEDER (1959).

\begin{tabular}{llll} 
Característica & & Categoria \\
Grau de integração & baixo & médio & alto \\
Densidade & baixa & média & alta \\
Grau de Uniformidade & não uniforme & pouco uniforme & uniforme \\
Orientação & não orientado & pouco orientado & orientado \\
Grau de controle & baixo & médio & alto \\
Ângulos de junção & agudos & retos & obtusos \\
Angularidade & baixa & média & alta \\
\hline
\end{tabular}

Como características quantitativas foram determi nados diversos índices relacionados em seguida. As caracterís ticas quantitativas foram determinadas nas bacias hidrográfi cas e amostras circulares. 


\section{$\underline{\text { Densidade de drenagem }}$}

A densidade de drenagem é expressa pela relação entre o comprimento total dos escoadouros da bacia ou amostra circular e a respectiva área, HORTON (1945) e FRANCA (1968). As designações desta característica foram Dd e Ddc, respectiva mente, para bacias hidrográficas e amostras circulares. A uni dade foi expressa em $\mathrm{km} / \mathrm{km}^{2}$.

\section{Frequência de rios.}

A frequência de rios é expressa pela relação en tre o número total de rios da bacia ou amostra circular e a respectiva ārea. As designações foram $\mathrm{F}$ e Fc, respectivamente, para bacias hidrográficas e amostras circulares. A unidade foi expressa em no de rios $/ \mathrm{km}^{2}$.

\section{$\underline{\text { Razão de textura }}$}

A razão de textura foi determinada, de acordo com FRANÇA (1968), relacionando o número total de rios da bacia ou amostra circular com os respectivos perímetros. As designações foram $T$ e TC, respectivamente, para bacias hidrográficas e amostras circulares. A unidade foi expressa em no de rios $/ \mathrm{km}^{2}$. Razão de textura média

A razão de textura média foi obtida pelo valor da média aritmética da razão de textura e pelo valor da média ponderada em relação às áreas das bacias, FRANÇA (1968). As de 
signações foram Tm e Tmc, respectivamente, para bacias hidro gráficas e amostras circulares. A unidade foi expressa em no de rios $/ \mathrm{km}$.

\section{Extensão do percurso superficial}

A extensão do percurso superficial é expressa pe la relação: Extensão do percurso superficial $=1 \times(2 \mathrm{Dd})^{-1}$, on de Dd é a densidade de drenagem, HORTON (1945). As designações foram Eps e Epsc, respectivamente, para bacias hidrográficas e amóstras circulares. A unidade foi expressa em quilômetro.

\section{Coeficiente de manutenção}

o coeficiente de manutenção é exp̣resso pela rela ção: Coeficiente de manutenção $=1000 \times(\text { dd })^{-1}$, schumm (1956). O coeficiente de manutenção representa a área mínima necessạ ria para a manutenção de um metro de canal escoadouro. As de signações foram $\mathrm{Cm}$ e $\mathrm{Cmc}$, respectivamente, para bacias hidro gráficas e amostras circulares. A unidade foi expressa em $\mathrm{m}^{2}$.

\section{Textura topogrāfica}

A identificação da classe de textura topográfica foi efetuada em função dos valores da razão de textura média, adotando-se a classificação de SMITH (1950), adaptada por FRAN ÇA (1968). Por essa classificação, os valores da razão de tex tura média menores que 2,5 são enquadrados na classe grosseira; os situados entre 2,5 e 6,2, na classe média e os valores aci ma de 6,2 , na fina. 
4.2.8.2. Composição da rede de drenagem

A composição da rede de drenagem foi caracterizą da determinando-se os diversos elementos relacionados em sequi da.

\section{Ordem de ramificação}

A ordem de ramificação dos canais escoadouros foi estabelecida adotando-se o sistema de Horton modificado por STRAHLER (1957). Os canais de drenagem foram designados simplesmente de segmentos de rios, conforme FRANÇA (1968) e a ordem de ramificação dos segmentos de rios foi designada gene ricamente pela letra $\mathrm{w}$.

\section{Número de segmentos de rios}

O número de segmentos de rios foi determinado paa ra cada ordem de ramificação e total da bacia, sendo designado, respectivamente, de $\mathrm{Nw}$ e N. Para cada unidade de solo foi cal culado também o número de segmentos de rios pelo empreqo da mé dia ponderada em relação às áreas das bacias, pela substitui ção numérica na equação de forma $\log \mathrm{Nw}=\log \mathrm{a}-\mathrm{w} \cdot \log \mathrm{b}, \quad \mathrm{MAX}$ WELL (1955) e pela lei do número de rios enunciada por HORTON (1945) .

\section{Comprimento total dos segmentos de rios}

o comprimento total dos segmentos de rios foi de terminado para cada ordem de ramificação e total da bacia. Pạ 
ra cada unidade de solo foi calculado também o comprimento to tal dos segmentos de rios pela média ponderada em relação às áreas das bacias, pelas substituições numéricas das relações $\log L w=\log a-w \cdot \log b$ e $\log L w=\operatorname{loa} a-b \cdot \log w, r e \underline{s}$ pectivamente de FRANÇA (1968) e STRAHLER (1957) e pela lei dos comprimentos de rios enunciada por HORION (1945). O comprimento total foi designado de Iw e Lt, respectivamente, para cada ordem de ramificacão e total da bacia.

\section{Comprimento médio dos segmentos de rios}

O comprimento médio dos segmentos de rios foi de terminado para cada ordem de ramificação e global da bacia, pe lo estabelecimento de uma relação entre comprimento total e nū mero de segmentos de rios. Para cada unidade de solo foi calcu ladio também o comprimento médio pela média ponderada em rela ção às áreas das bacias, pela substituição numérica da relação $\log \mathrm{Lm}=\log \mathrm{a}-\mathrm{w} \cdot \log \mathrm{b}$, VASOQUES FILHO (1972), pela relação entre comprimento total e número de rios em cada ordem ( $\mathrm{Lw}$ e NW) obtidos respectivamente pelas relações de FRANÇA (1968) e MAXWELL (1955) e pela lei dos comprimentos de rios enunciada por HORTON (1945). O comprimento médio foi designado por Lm.

\section{$\underline{\text { Razão de } \text { ramificação }}$}

A razão de ramificação foi estabelecida pela re lação entre os números de segmentos de rios de duas ordens con secutivas. Os valores médios da razão de ramificação foram de terminados pela média aritmética dos dados observados, pelas relações $\mathrm{Rb}=$ antilog $\mathrm{b}, \mathrm{MAXWELL}$ (1955) e Rb $=\mathrm{R} l \mathrm{~m} \times \mathrm{Rlw}$, FRAN 
ÇA (1968). A razão de ramificação foi designada por $\mathrm{Rb}$.

\section{$\underline{\text { Razão de comprimentos totais }}$}

A razão de comprimentos totais foi estabelecida pela relação entre os comprimentos totais dos segmentos derios de uma dada ordem (lw) e os da ordem imediatamente superior, STRAHLER (1957). Os valores médios da razão de comprimentos to tais foram determinados pela média aritmética dos dados obser vados e pelas relações $\mathrm{Rlw}=$ antilog $\mathrm{b}$ e $\mathrm{Rlw}=\mathrm{Rb} \times \mathrm{Rlm}^{-1}$, FRAN ÇA (1968). A razão de comprimentos totais foi designada por Rlw.

$\underline{\text { Razão de comprimentos médios }}$

A razão de comprimentos médios foi estabelecida pela relação entre os comprimentos médios de segmentos de rios de uma dada ordem e os da ordem imediatamente inferior, HORTON (1945). Os valores médios foram determinados pela média arit mética dos dados observados e pelas relações $\mathrm{Rlm}=$ antilog $\mathrm{b}$ e $\mathrm{Rlm}=\mathrm{Rb} \times \mathrm{Rlw}^{-1}$, respectivamente, VASOUES FILHO (1972) e FRAN ÇA (1968). A razão de comprimentos médios foi designada por Rlw.

4.2.9. Anālise de variância

A análise de variância foi emnrenada nara diver. sas características das bacias hidrográficas e ras redes de drenagem, sendo estabelecidos delineamentos experimen 
tais inteiramente casualizados, adotando-se o método descrito em PIMENTEL GOMES (1963).

$\mathrm{Na}$ anālise de variância procurou-se evidenciar as diferenças entre unidades de solos, sistemas de amostragens e interação entre sistemas de amostragem e unidades de solos pelo teste $\mathrm{F}$.

4.2.10. Relações entre características

Adotando-se procedimentos de SMITH (1950), STRAH LER (1957), FRANÇA (1968), que foram seguidos por outros pes quisadores, procurou-se estabelecer algumas relações funcio nais, estudando o ajustamento dos dados das características das baciias, e redes de drenagem à equação de regressão tipo linear. Procurou-se estabelecer também esse tipo de relações entre as características determinadas pelos dois critérios de amostra gem.

Dos dados determinados em bacias hidrográficas foram estabelecidas relações entre as seguintes característi cas: densidade de drenagem (Dd) e frequência de rios (F); den sidade de drenagem (Dd) e razão de textura (T); densidade de drenagem (Dd) e extensão do percurso superficial (Epss); densi dade de drenagem (Dd) e razão de relevo ( $R r)$; densidade de dre nagem (Dd) e coeficiente de massividade (Cmass); densidade de drenagem (Dd) e coeficiente orográfico (Cor); frequência de 
rios (F) e razão de textura ( $T$ ) ; frequência de rios (F) e ex tensão do percurso superficial (Eps); frequência de rios (F) e coeficiente de manutenção $(\mathrm{Cm})$; frequência de rios (F) e razão de relevo (Rr); frequência de rios (F) e coeficiente de massi vidade (Cmass); frequência de rios (F) e coeficiente orográfi co (Cor): razão de textura (T) e extensão do percurso superfi cial (Eps); razão de textura (T) e coeficiente de manutenção $(\mathrm{Cm})$; razão de textura $(\mathrm{T})$ e razão de relevo ( $\mathrm{Rr})$; razão de textura (T) e coeficiente de massividade (Cmass); razão de tex tura (T) e coeficiente orográfico (Cor); extensão do percurso superficial (EPs) e razão de relevo ( $R r)$; extensão do percurso superficial (Eps) e coeficiente de massividade (Cmass): exten são do percurso superficial (Eps) e coeficiente orográfico (Corr); coeficiente de manutenção (Cm) e razão de relevo ( $\mathrm{Rr}$ ); coeficiente de manutenção $(\mathrm{Cm})$ e coeficiente de massividade (Cmass); coeficiente de manutenção $(\mathrm{Cm})$ e coeficiente orográfi co (Cor); razão de relevo ( $R r)$ e coeficiente orográfico (Cor) e coeficiente de massividade (Cmass) e coeficiente orográfico (Cor)

Dos dados determinados em amostras circulares fo ram estabelecidas as relações entre as seguintes característi cas: densidade de drenagem (Ddc) e frequência de rios (FC); den sidade de dreangem (Ddc) e razão de textura (Tc); densidade de drenagem (DdC) e extensão do percurso superficial (Epsc); den sidade de drenagem (Ddc) e coeficiente de manutenção (Cmc); 
frequência de rios (FC) e extensão do percurso superficial (Epsc); frequência de rios (FC) e coeficiente de manutenção (Cmc) ; razão de textura (Tc) e extensão do percurso superfi cial (Epsc); razão de textura (TC) e coeficiente de manutenção (Cmc) e extensão do percurso inicial (Epsc) e coeficiente de manutenção $(\mathrm{Cmc})$.

Para verificar a interação entre os sistemas de amostragem foram estabelecidas relações entre as seguintes ca racterísticas: densidade de drenagem (Dd) e densidade de drena gem (DdC); frequência de rios (F) e frequência de rios (FC); rạ zão de textura (T) e razão de textura (TC); extensão do percur so superficial (Eps) e extensão do percurso superficial (Epsc); coeficiente de manutenção $(\mathrm{Cm})$ e coeficiente de manutenção (Cric); densidade de drenagem (DdC) e frequência de rios (FC); densidade de drenagem (Dd) e razão de textura (TC); densidade de drenagem (Dd) e extensão do percurso superficial (Epsc); den sidade de drenagem (Dd) e coeficiente de manutenção (Cmc); den sidade de drenagem (Ddc) e frequência de rios (F); densidade de drenagem (Ddc) e extensão do percurso superficial (Epss); densi dade de drenagem (Ddc) e coeficiente de manutenção (Cm); fre quência de rios (F) e razão de textura (TC); frequência de rios (F) e extensão do percurso superficial (Epsc); frequência de rios (F) e coeficiente de manutenção ( $\mathrm{Cmc}$ ); frequência de rios (F) e razão de textura (T); frequência de rios (FC) e ex tensão do percurso superficial (Eps); frequência de rios (FC) 
e coeficiente de manutenção $(\mathrm{Cm})$; razão de textura (T) e exten são do percurso superficial (Epsc); razão de textura ( $t$ ) e coe ficiente de manutenção (CMc); razão de textura (Tc) e extensão do percurso superificial (Eps); razão de textura (Tc) e coefi ciente de manutenção $(\mathrm{Cm})$; extensão do percurso sup̣erficial (Eps) e coeficiente de manutenção $(\mathrm{Cmc})$ e extensão do percu $\underline{r}$ so superficial (Cmc) e coeficiente de manutenção (Cm) . 
5. RESUltados e Discuss ̃̃o

Os resultados obtidos são apresentados e discuti dos em seguida.

5.1. Bacias Hidrográficas

As bacias hidrográficas representando as āreas de ocorrência da unidade de Solos Podzolizados de Lins e Marí lia - var. Marília são apresentados nas figuras 4 e 5 e as ba cias da unidade Solos Podzólico Vermelho--Amarelo - var. Laras, as figuras 6 e 7. Para cada área de ocorrência de solos foram selecionadas quatro bacias hidrográficas com características que satisfazem as premissas do critério de semelhança geométrí ca de STRAHLER (1957). 


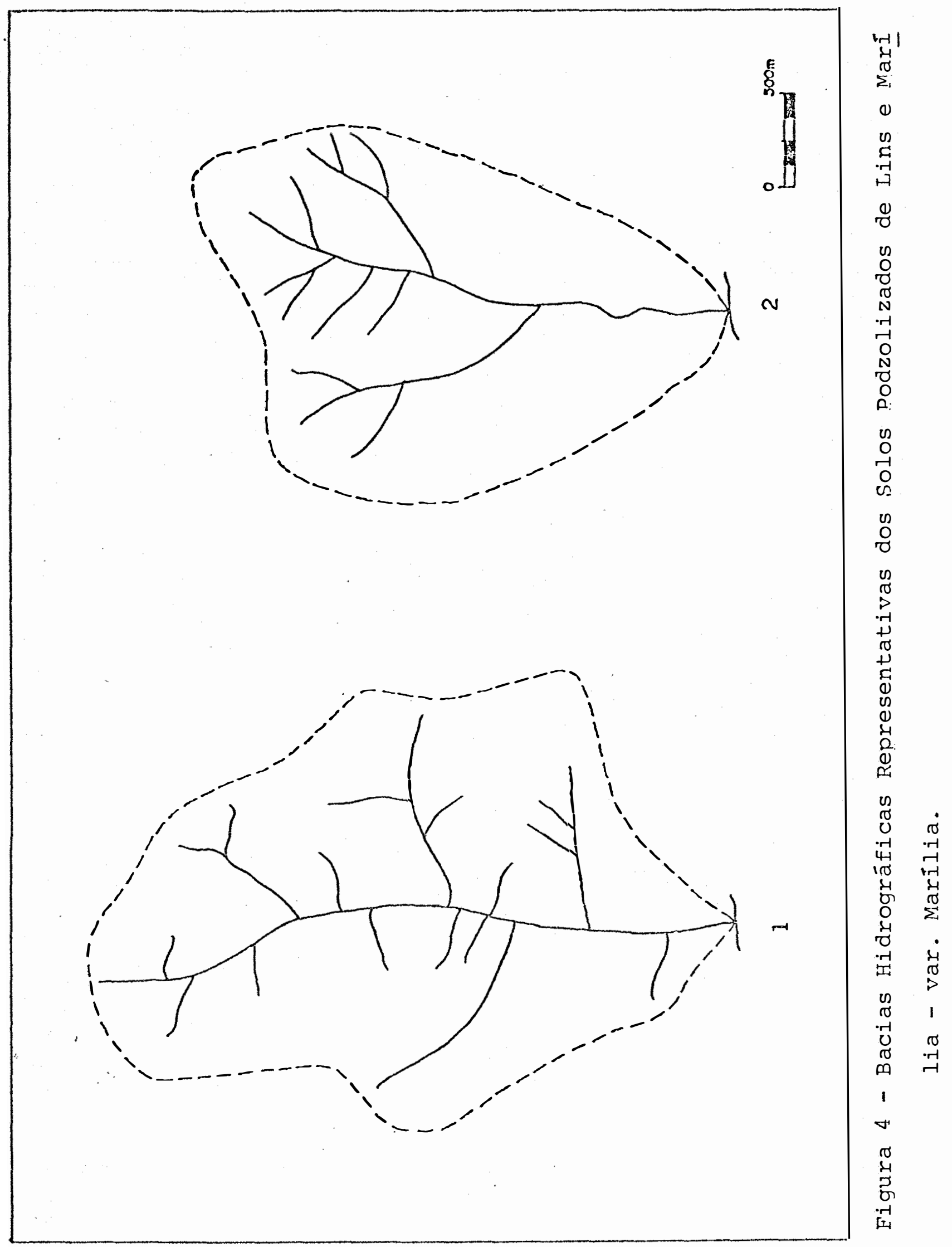




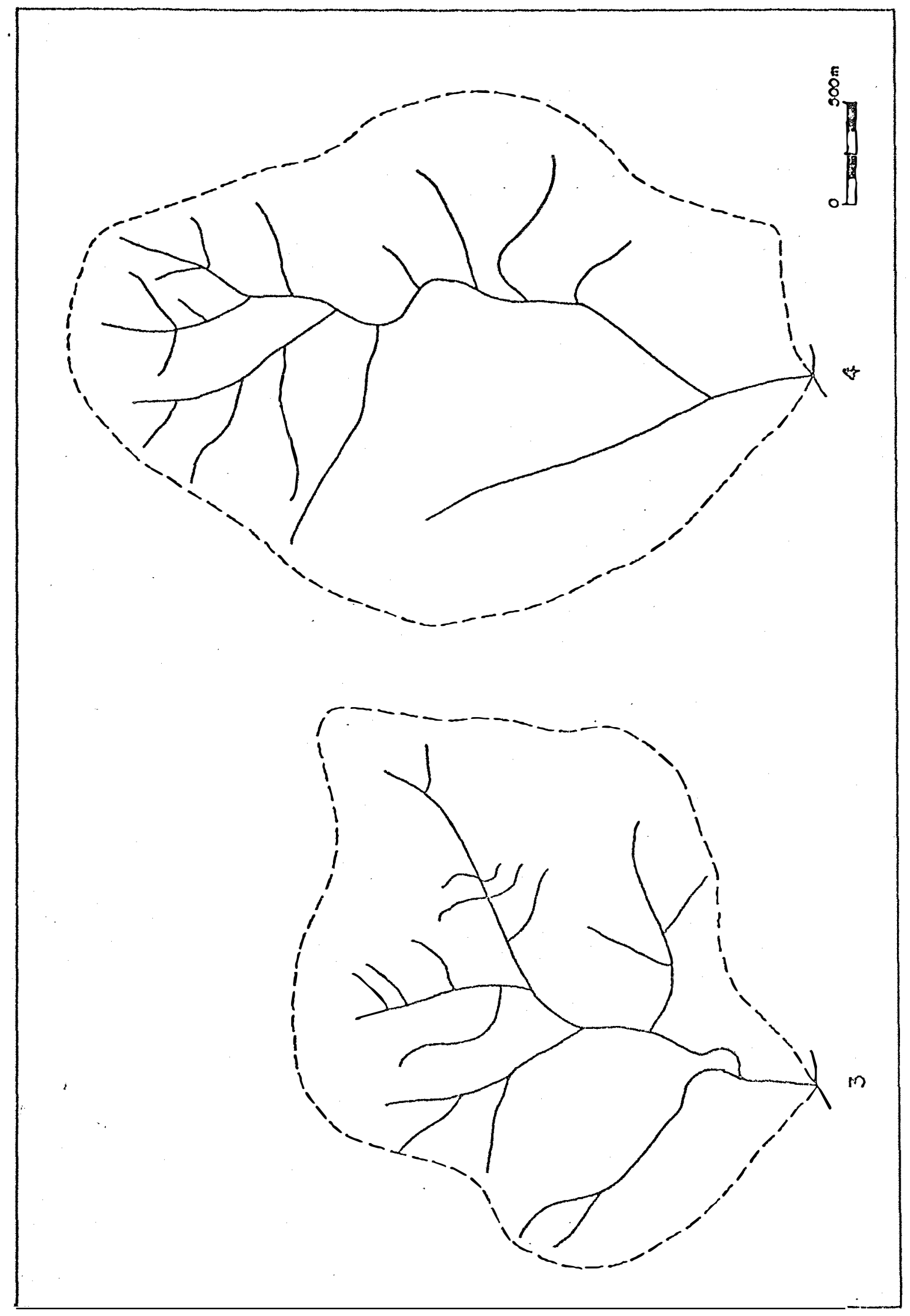

म्.

1
0
0
-7
-1

ष्ठ

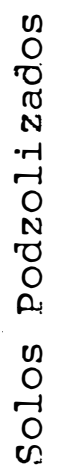

$\stackrel{0}{0}$

U

D

$+$

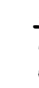

o

म्.

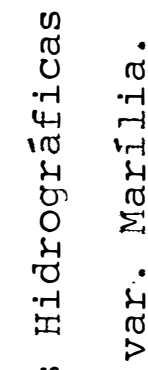

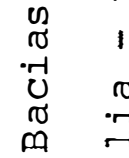

1

in

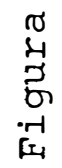


74.

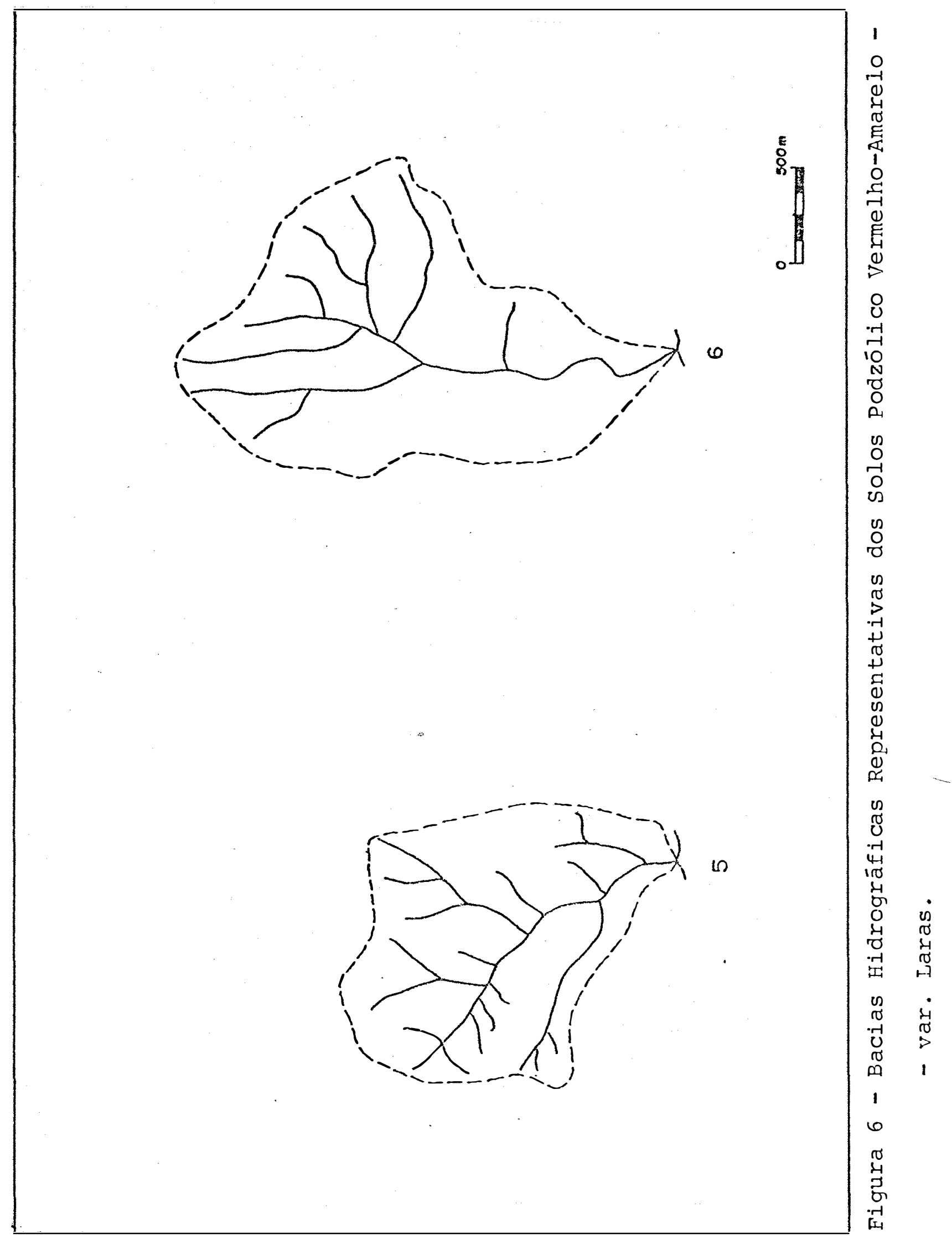




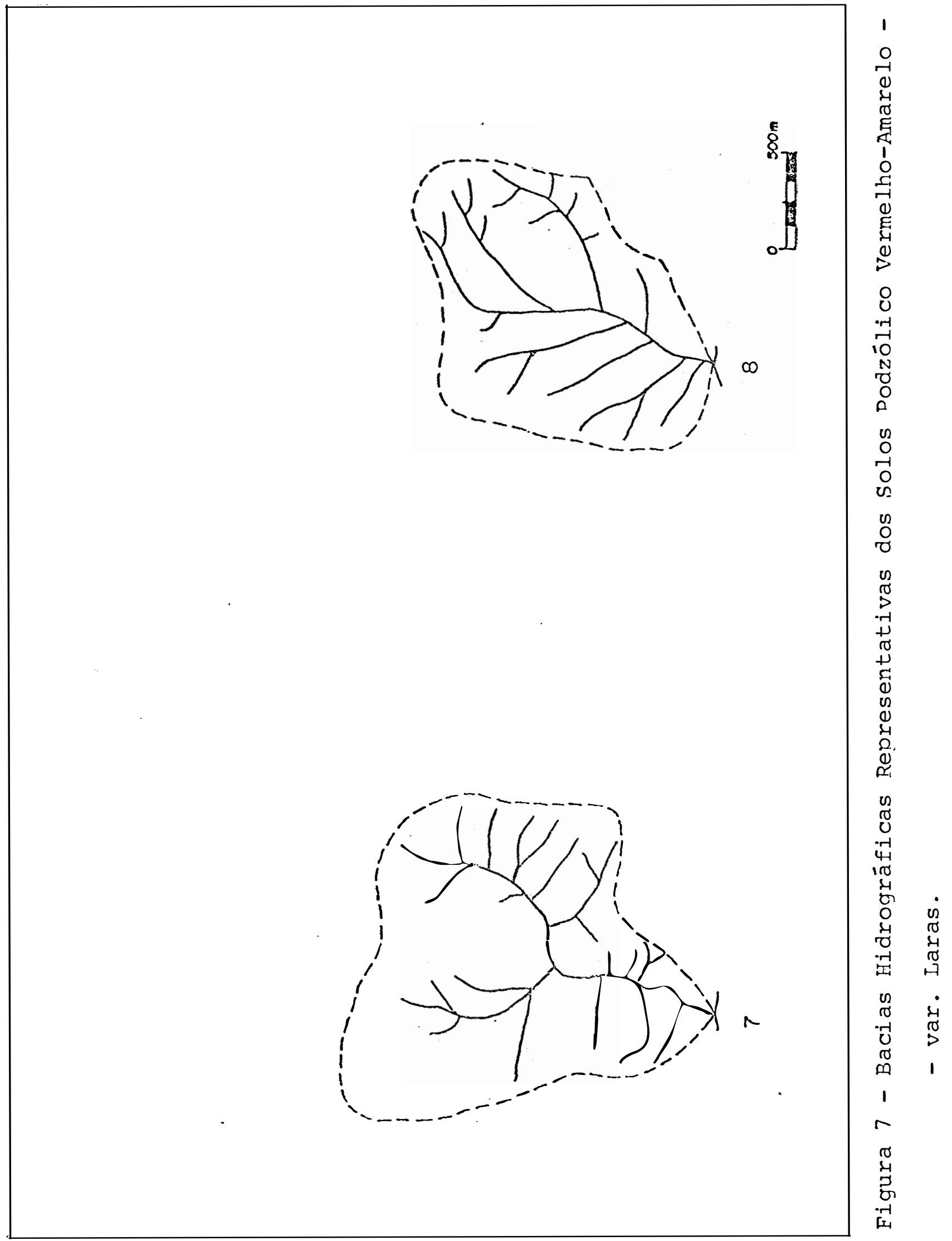




\subsubsection{Localização}

As bacias da unidade Solos Podzolizados de Lins e Marília - var. Marília estão localizados numa área que ocup̣a partes da região noroeste do Município de Jaboticabal, da nor deste do Município de Monte Alto e da região sudeste do Municí pio de Taiuva. A bacia de no l está situada na margem direita de um tributário da margem esquerda do córrego Tijuco preto. A bacia de nọ 2 está localizada na margem direita do córreço da Grama, o qual é tributário da margem direita do córreqo da Estiva. A bacia de no 3 está situada na marạem direita do cór rego da Estiva, em posição bem próxima de sua cabeceira e a ba cia de nọ 4, está situada na margem esquerda do mesmo córrego.

As bacias da unidade Solos Podzólico Vermelho-Amarelo - var. Laras estão localizados numa área que ocup̣a partes das regiões leste do Município de Piracicaba e da re gião oeste do Município de Santa Bárbara do Oeste. A bacia de ne 5 está situada na margem esquerda do córrego Santa Fé, o qual é tributário da margem direita do Ribeirão Tijuco Preto, sendo este afluente da margem esquerda do rio Piracicaba. A ba cia de no 6 está localizada na margem direita do rio Piracica ba. A bacia de no 7 está situada na cabeceira do córrego Que bra-Dente, o qual é afluente da margem esquerda do ribeirão Lambari, sendo este tributário da margem esquerda do rio Pira cicaba e a bacia de no 8 está localizada na cabeceira de um 
cōrrego tributário da margem esquerda do ribeirão Lambari, em sua posição mediana.

5.1.2. Representatividade

As bacias da unidade Solos Podzolizados de Iins e Marília - var. Marília possuem a unidade principal de ocor rência associada a Solos Aluviais e Hidromórficos, localiza dos em faixas estreitas ao longo dos cursos d'āgua e a solos Litólicos que estão situados em faixas bastante estreitas jun to às linhas de ruptura de declives. A ocorrência dos Solos Li tólicos abrange 15 a 20\% de área global de cada bacia. Nesta ārea, os solos associados näo foram considerados como inclu são, por estarem ligados à unidade principal pelas condições de relevo. Considerou-se pelas condições relatadas, que as bạ cias selecionadas apresentam alta representatividade da unida de principal.

As bacias da unidade Solos Podzólico vermelho -

- Amarelo - var. Laras apresentam a unidade principal associa da a Solos Aluviais, Hidromórficos e a Solos Litólicos, situa dos em posições relacionadas às condições de relevo. A ocorrên cia de Solos Litólicos abrange cerca de 25\% da área global de cada bacia. Nas bacias de números 5 e 6 foi verificada a inclu são do Latossol Vermelho Escuro - orto nas posições de cotas mais elevadas, ocupando aproximadamente 10\% das suas āreas. Con 
siderou-se que as bacias selecionadas apresentam alta represen tatividade da unidade principal de ocorrência.

5.1.3. Semelhança geométrica

Os dados da análise dimensional e teste de seme Ihança geométrica das bacias são apresentados no quadro 4 . Nes te quadro, os valores da razão média (Rm) representaram a mé dia das diversas relações estabelecidas entre os elementos considerados na razão da escala linear e os valores da razão de escala quadrática representaram relações entre áreas das ba cias e os valores elevados ao quadrado da razão média ( $\mathrm{Rm}^{2}$ ). As diferenças entre os valores das razões de área e os valores da razão média elevados ao quadrado, mostradas na última colu na, foram pequenas em cada grupo de bacias, satisfazendo o cri tério de semelhança geométrica de STRAHLER (1957).

5.1.4. Características não dimensionais

As características não dimensionais, forma da ba cia e simetria das vertentes são anresentadas no cuadro 5 . 


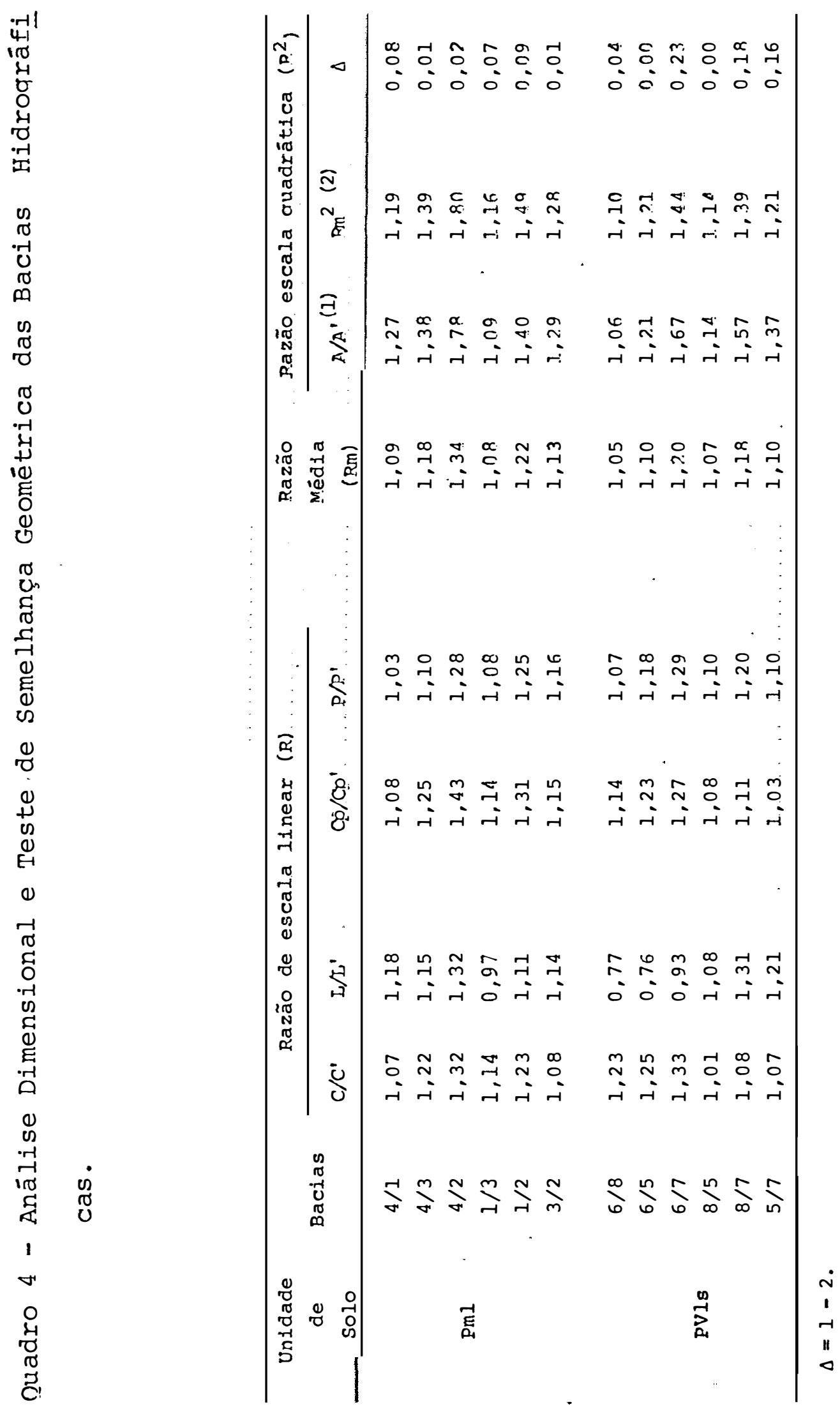


Quadro 5 - Características Não Dimensionais das Bacias Hidro gráficas.

\begin{tabular}{lcll}
\hline Unid. Solo & Bacia & Forma Aproximada & Simetria das Vertentes \\
\hline Pnl & 1 & Trapezoidal & Pouco simétrica \\
& 3 & Triang. Isósceles & Pouco simétrica \\
& 4 & Oval normal & Assimétrica \\
& 5 & Trapezoidal & Assimétrica \\
PVls & 6 & Triang. Isósceles & Pouco simétrica \\
& 7 & Trapezoidal & Assimétrica \\
& 8 & Trapezoidal & Assimétrica \\
\hline
\end{tabular}

Nas duas unidades de solos foi verificado que as bacias apresentam formas diferentes e simetrias das vertentes distintas, revelando modificações dos comportamentos hidrolóxi cos e fisiográfico das bacias, embora dentro da mesma unidade de solo. Estas condições provavelmente foram impostas pelos controles estrutural e topográfico e pelas inclusões de outros tipos de solos. As variações de forma e simetria das vertentes são, de maneira geral, comumente observadas nas áreas de solos podzolizados, conforme verificou-se em FRANCSA (1968), MARCHET TI (1969) e VASQUES FILHO (1972). 
As bacias hidrográficas foram classificadas como de $3^{\mathrm{a}}$. ordem, segundo o sistema de Horton modificado por STRA LER (1957).

\subsubsection{Características dimensionais}

As características dimensionais, maior comprimen to (C), maior largura (L), comprimento do rio principal (Cp), comprimento total da rede $(\mathrm{Cr})$, perímetro (P), ārea (A), indi ce de circularidade $\left(I c_{1}\right)$ e indice de compacidade $\left(I c_{2}\right)$ são apresentadas no quadro 6 . Os respectivos valores médios e er ros padrões da média $[s(m)]$ são reunidos no quadro 7 e a análi se de variância consta do quadro 8 .

As características das bacias da unidade Solos Podzolizados de Lins e Marília - var. Marília apresentaram, de maneira geral, valores médios mais altos, revelando aue as condições de drenagem dos perfis de solos estão diretamente re lacionadas com as características analisadas. De maneira geral, - aumento da restrição de drenagem dos perfis está ligado à dí minuição da área, do perímetro, do comp̣rimento e da larquuradas bacias e com a diminuição dos comprimentos do rio princinal e da rede, confirmando resultados de FRANCA (1968) e VASOUES FI LHO (1972). Os valores do erro padrão da média dos dados da 
unidade Solos Podzólico Vermelho-Amarelo - var. Laras, sendo, em geral, menores, indicam a maior homogeneidade de suas bacias.

Quadro 6 - Valores Médios e Erros Padrões da Média das Caracte rísticas Dimensionais das Bacias Hidrográficas.

\begin{tabular}{|c|c|c|c|c|}
\hline \multirow{2}{*}{ Característica } & \multicolumn{2}{|r|}{$\mathrm{Pml}$} & \multicolumn{2}{|c|}{ PVIs } \\
\hline & V. Médio & $\begin{array}{c}\text { Erro P. Média } \\
\mathrm{s}(\mathrm{m})\end{array}$ & V. Médio & $\begin{array}{l}\text { Erro P. Média } \\
\text { s(m) }\end{array}$ \\
\hline Maior comp. (C) & 2,63 & 0,164 & 1,68 & 0,108 \\
\hline Maior larg. (L) & 1,94 & 0,107 & 1.16 & $0,0 \overline{2} 2$ \\
\hline Comp. rio princ. (Cp) & 2,60 & 0,202 & 1,74 & 0,090 \\
\hline Comp. T. rede $(\mathrm{Cr})$ & 9,42 & 1,010 & 7,13 & 0,490 \\
\hline Perímetro (P) & 7,32 & 0,421 & 4,77 & 0,261 \\
\hline Área (A) & 3,58 & 0,420 & 1,43 & 0,150 \\
\hline I. circularidade $\left(I_{1}\right)$ & 0,831 & 0,030 & 0,775 & 0,029 \\
\hline I. compacidade $\left(\mathrm{IC}_{2}\right)$ & 1,092 & 0,020 & 1,123 & 0,184 \\
\hline
\end{tabular}

Pela análise de variância verificou-se que

as características maior comprimento, maior largura, comprimento do rio principal, perímetro e área ap̣resentaram diferenças sị nificativas, a nível de l\% de probabilidade, entre solos. As características comprimento total da rede e os índices de cir cularidade e compacidade não se apresentaram sensiveis às des conformidades dos comportamentos hidrológicos dos solos, exi bindo valores de F não significativos. Os coeficientes de va riação dos índices de circularidade e de compacidade, com valo res menores que 10\%, foram classificados como baixos; os dos 


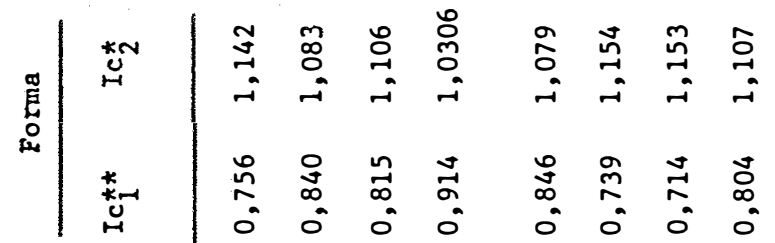

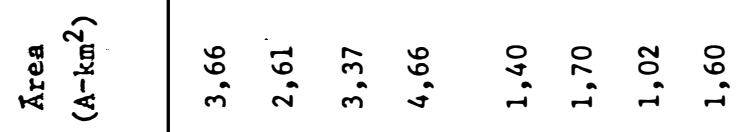

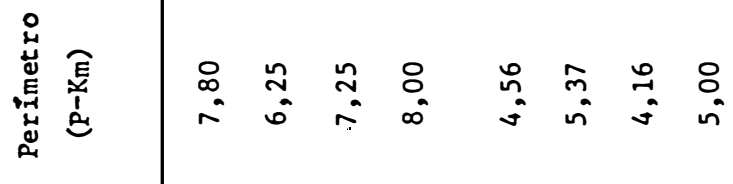

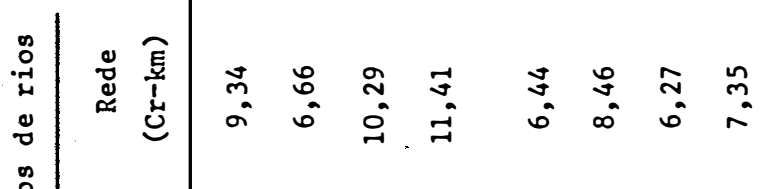

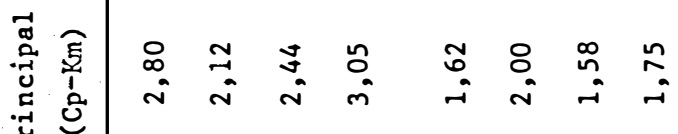

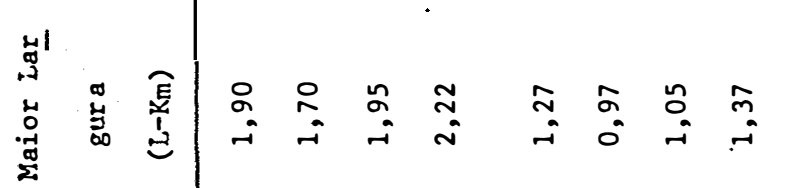

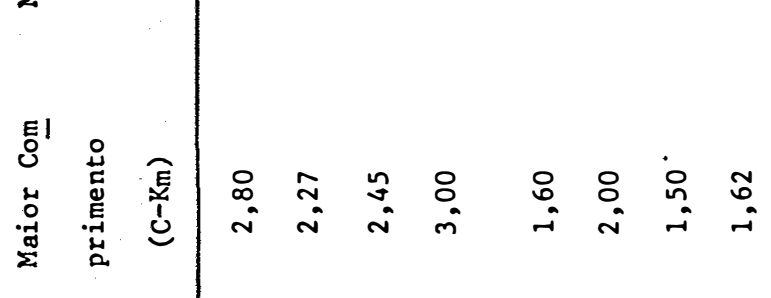

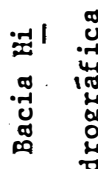

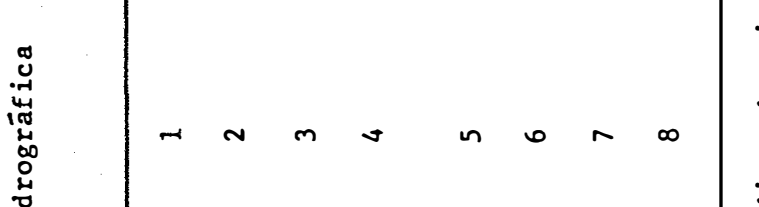

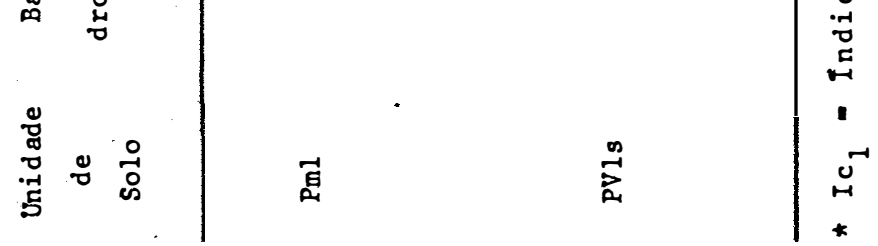


84.

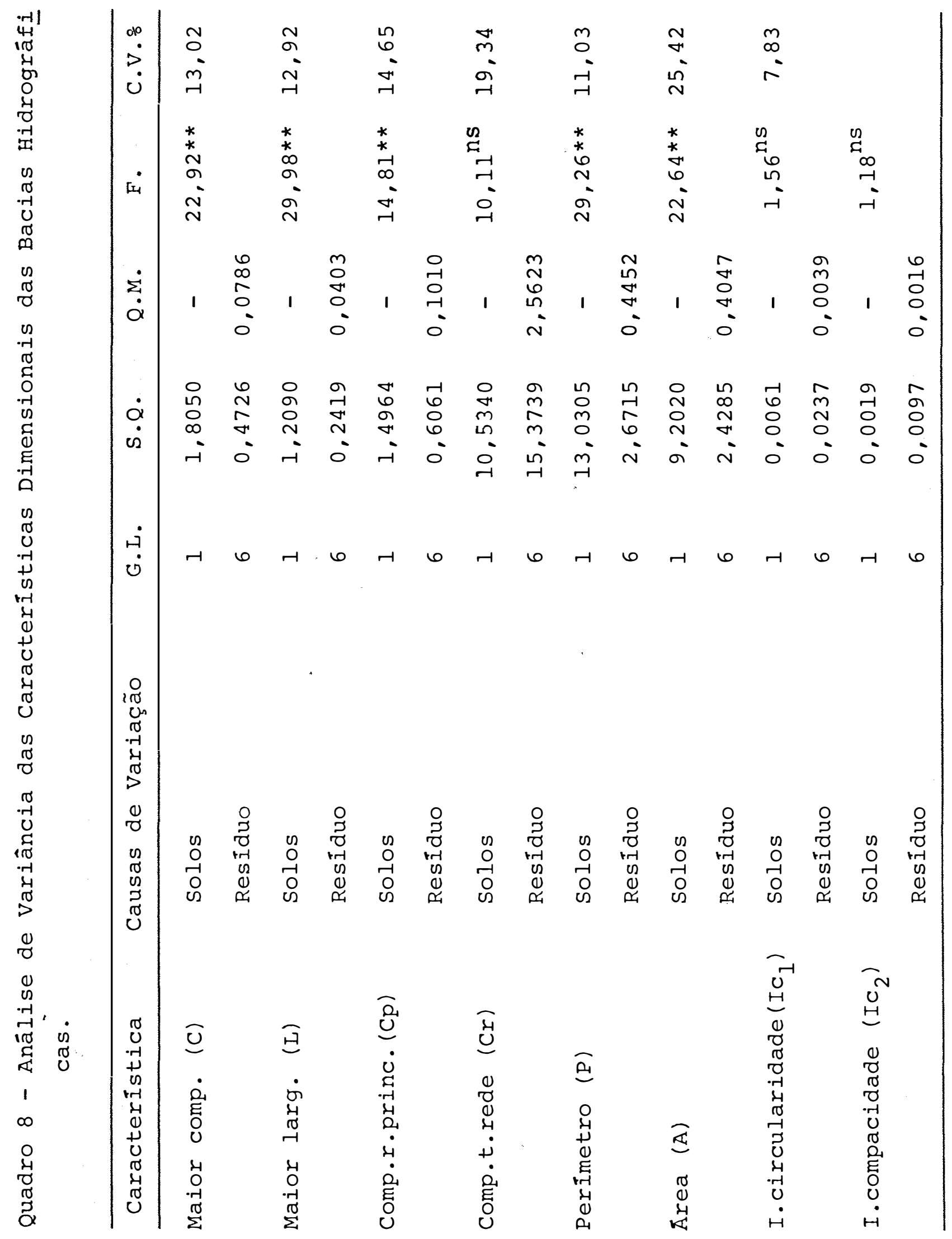


Indices maior comprimento, maior largura, comprimento do rio principal, comprimento total da rede e perímetro, com valores entre 10 e 20\%, foram classificados como médios e o coeficien te de variação do indice área, situado entre 20 e $30 \%$, foi classificado como alto, indicando, respectivamente, homogenei dade, certa homogeneidade e certa heterogeneidade dos dados ob servados. Os resultados apresentados pelos índices que retra tam a forma da bacia estão em conformidade com FRANCA (1968), MARCHETTI (1969), FADEL (1972) e VASONUES FILHO (1972) e os da área confirmaram somente os resultados de VASỌUES FILHO (1972). Os valores dos índices de forma indicam que as bacias apresen tam formas que se acercam das do círculo, fato este evidencia do pela impossibilidade da ap̣licação da fórmula do retâng̣ulo equivalente de Lanabein (1947), para a determinação da declivị dade média de cinco bacias.

As características dimensionais determinadas pe la análise hipsométrica e a respectiva análise de variância são apresentadas nos quadros 9 e 10 .

A integral hipsométrica apresentou valores leve mente superiores na unidade Solos Podzolizados de Lins e Marí lia - var. Marília.

Os valores da amplitude altimétrica e da altura média praticamente não diferiram nas duas unidades de solos, o que pode ser explicado pela existência de relevo tabular nas duas áreas de estudo. 


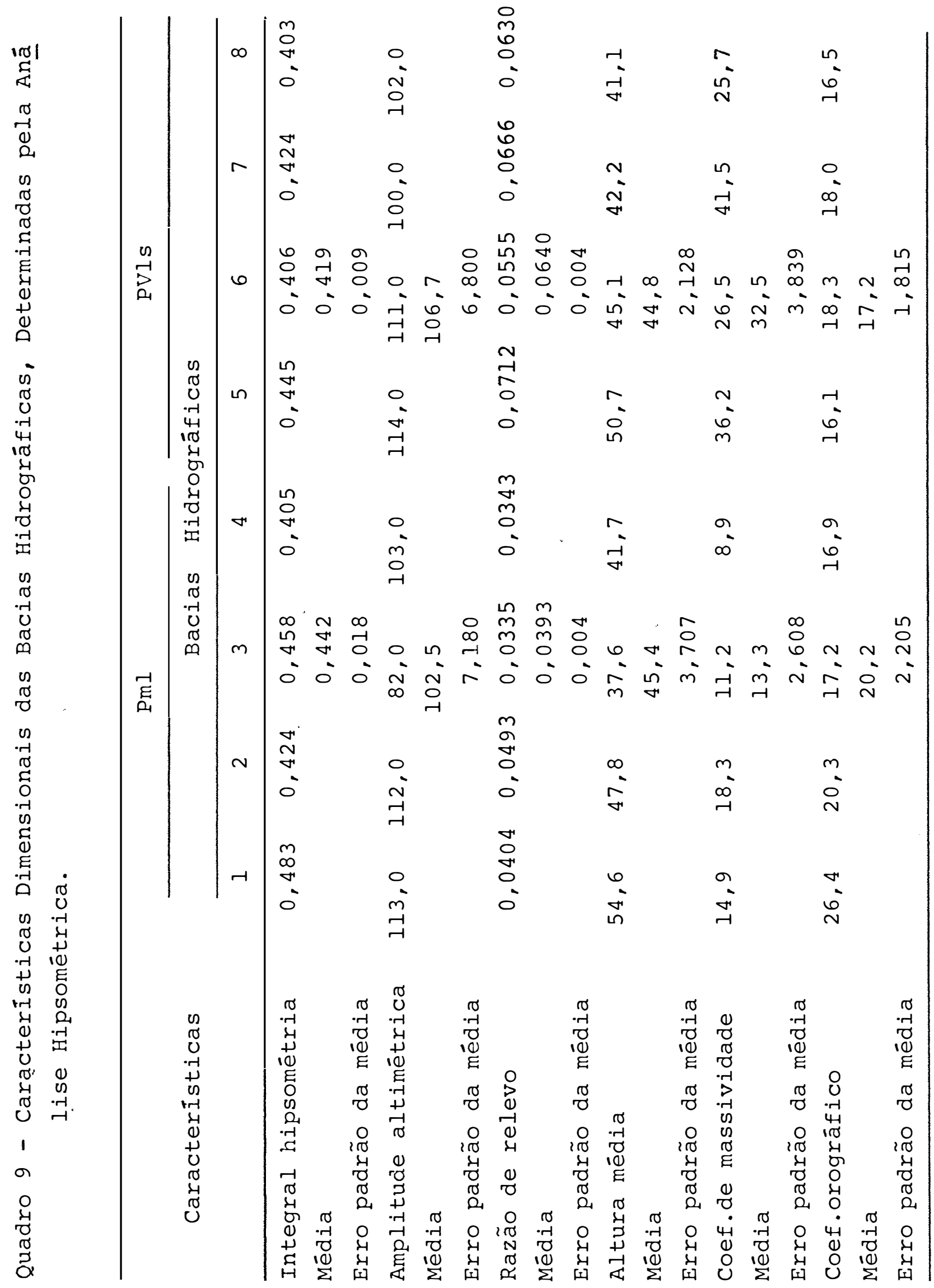




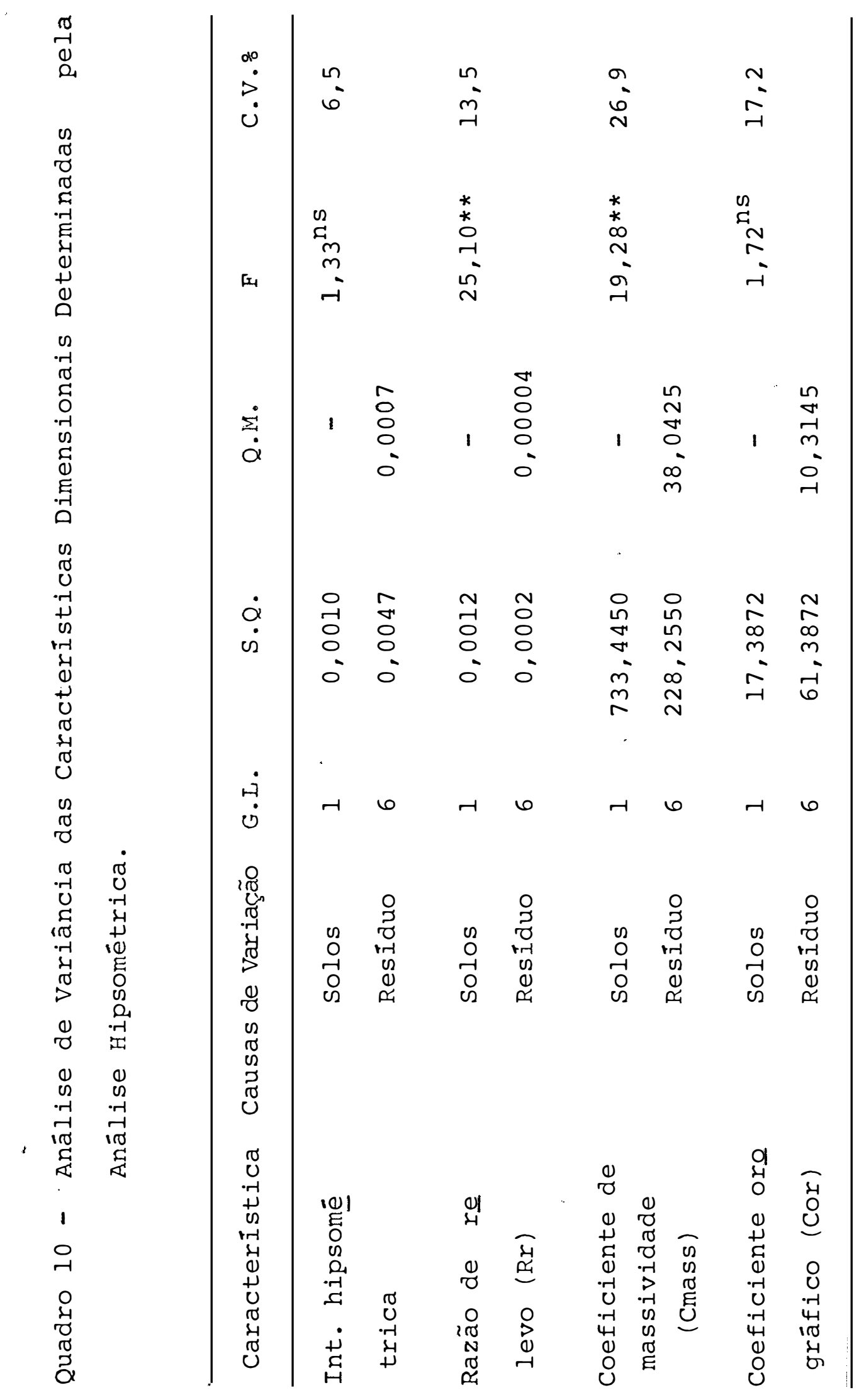


Os valores da razão de relevo e coeficiente de massividade da unidade Solos Podzólico Vermelho-Amarelo - var. Iaras, sendo superiores, mostraram que a maior restrição da drenagem dos perfís de solos está relacionada com a maior dis secação do relevo. Sendo altamente significativas as diferen Ças destas características entre solos, revelou-se a aptidão destes índices para a diferenciação de solos.

Os valores do coeficiente orográfico foram leve mente superiores na unidade Solos Podzolizados de Lins e Marí lia - var. Marília.

A classificação dos valores do coeficiente de vâ riação destes índices foi baixo para os da integral hipsométri ca, médios para os da razão de relevo e coeficiente orơráfico e alto para o do coeficiente de massividade, indicando, respec tivamente, homogeneidade, certa homogeneidade e certa heteroge neidade dos dados observados.

As curvas hipsométricas das bacias hidroqráficas são apresentadas nas figuras 8 e 9 .

As curvas hip̣sométricas da unidade Solos podzóli co Vermelho-Amarelo - var. Laras apresentaram-se mais semelhan tes, revelando maior homogeneidade das condições topọráficas de suas bacias.

As curvas da unidade Solos Podzolizados de Lins e Marília - var. Marília mostraram diferenças que revelaram desconformidades topogräficas de suas bacias, provavelmente as 


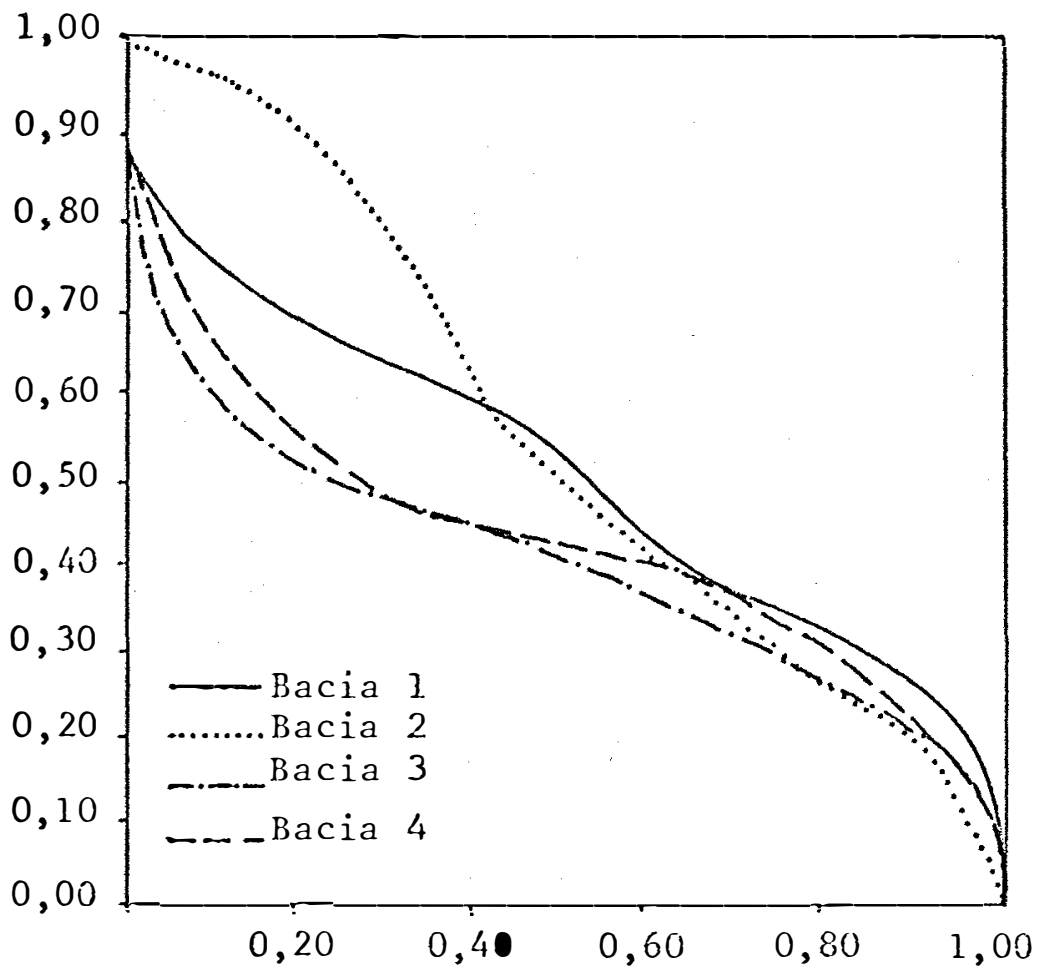

Figura 8 - Curvas Hipsométricas das Bacias Hidrográficas Repre sentativas da Unidade Solos Podzolizados de Lins e Marília - var. Marília. 


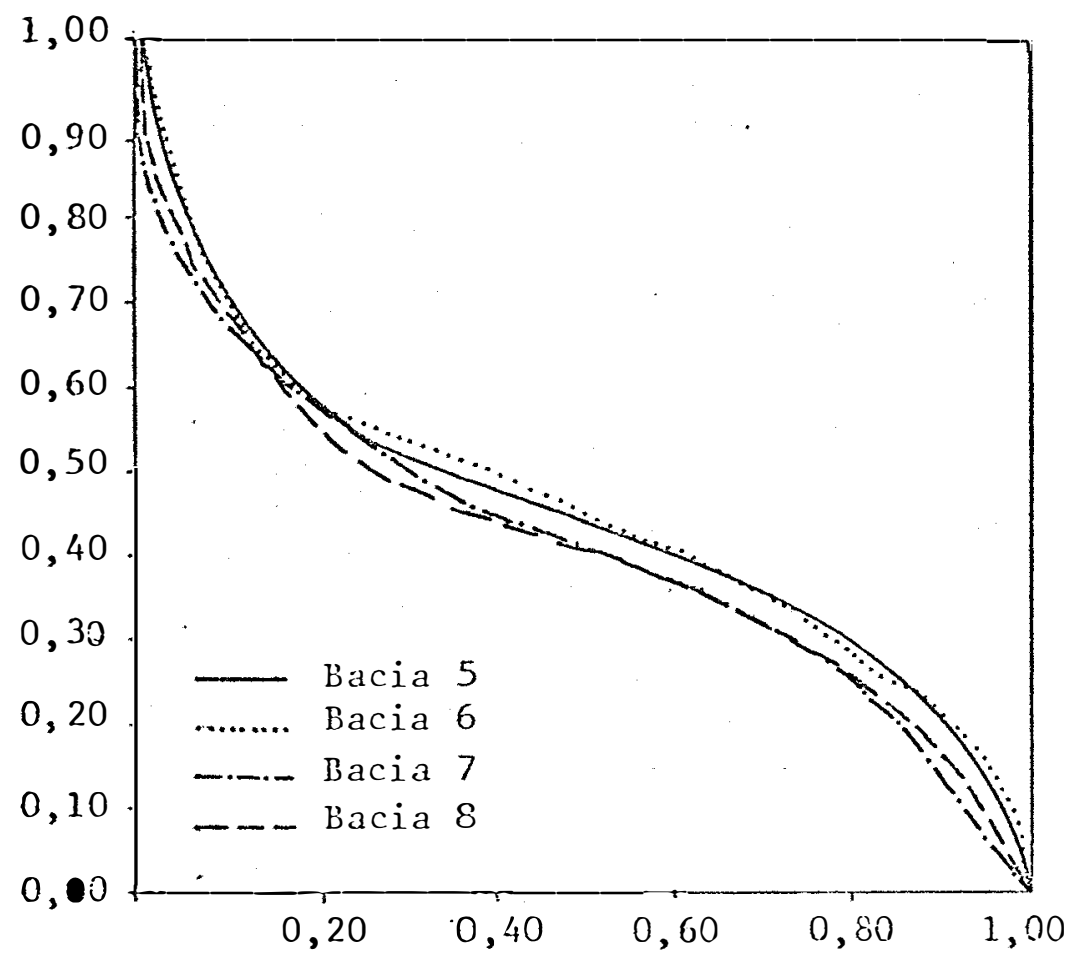

Figura 9 - Curvas Hipsométricas das Bacias Hidrográficas Renre sentativas da Unidade Solos Podzólico Vermelho- Ama relo - var. Laras. 
sociadas a modificações do processo erosivo, decorrentes de efeitos mais intensos da ação dos controles estrutural e topo gráfico.

De maneira geral, as curvas hipsométricas não se revelaram eficientes para diferenciar os solos, indicando ape nas diferenças dos estágios do ciclo erosivo do relevo. O rele vo da unidade Solos Podzólico Vermelho-Amarelo - var. Laras po de ser caracterizado no estágio de equilíbrio ou maturidade e o da unidade Solos Podzolizados de Lins e Marília- var. Marí lia, no estágio de senilidade, sequndo STPAHLER (1957).

5.2. Redes de Drenagem

5.2.1. Padrões de Drenagem

A análise dos padrões de drenagem foi realizada determinando-se suas características descritivas e quantitati vas.

5.2.1.1. Características descritivas

As características descritivas dos padrões de drenagem são apresentadas no quadro 11 . 
Quadro 11 - Características Descritivas dos Padrões de Drena gem.

\begin{tabular}{|c|c|c|}
\hline \multirow{2}{*}{ Característica } & \multicolumn{2}{|c|}{ Características } \\
\hline & PInl & PVIs \\
\hline Tipo ou modelo & Dendrítio & Dentrítioo modificado \\
\hline Densidade & Média & Alta \\
\hline Grau de Integração & Alto & Alto \\
\hline Grau de Uniformidade & Pouco uniforme & Pouco uniforme \\
\hline Orientação & Pouco orientado & Orientado \\
\hline Grau de controle & Médio & Alto \\
\hline Ângulos de junção & $\begin{array}{l}\text { Agudos e muito pouco } \\
\text { frequentemente retos }\end{array}$ & $\begin{array}{l}\text { Agridos e frequentemen } \\
\text { te retos }\end{array}$ \\
\hline Angularidade & Baixa & Média \\
\hline Anomalias & $\begin{array}{l}\text { Variações localizadas } \\
\text { da densidade }\end{array}$ & $\begin{array}{l}\text { Variações localizadas } \\
\text { da densidade }\end{array}$ \\
\hline
\end{tabular}

As diferenças observadas nas características des critas, embora tenham prop̣iciado indícios para a distinção dos solos, apresentam significados subjetivos. O tipo ou modelo exibiu diferenças que não podem ser relacionadas aos efeitos da diferenciação hidrológica dos solos, estando provavelmente ligadas às diferentes condições estruturais ou topoọráficas das āreas, confirmando observações de VASQUES FILHO (1972). A esse respeito, diversos pesquisadores como TATOR (1954), MILLER 
e MILLER (1961), RAY (1963), RICCI e PETRI (1965) e FRANCA (1968), baseados na diversidade dos padrões existentes e na ocorrência de anomalias, observaram que a simples descrição do tipo ou modelo do p̣adrão de drenagem não é eficiente para estą belecer diferenças entre formações superficiais ou litológicas. HORTON (1945) considerou que a simples descrição do tip̣o ou mo delo não fornece dados adequados para caracterizar as redes de drenagem quanto as diferenças dos comportamentos hidrológicos das áreas, porque um mesmo tipo ou modelo pode resultar de di versas combinações de números e comprimentos de rios.

A densidade apresentou diferenças entre os solos que revelam estar relacionada com as condições de drenaquem dos perfis. A classificação da densidade foi média para as condi çõès de drenagem boa e alta para a drenagem moderada, verifi cando-se por estes resultados, a oportunidade das sugestões pre conizadas por MILLER e MILLER (1961), RAY (1963) e RICCI e PE TRI (1965) de se descrever o tipo ou padrão em combinação com esta caracteristica.

A orientação, o grau de controle e a angularidą de apresentaram diferenças entre os solos que provavelmente es tão mais relacionadas com os controles estruturais ou topoorra ficos das áreas, que às diferenças de solos.

O grau de integração, o grau de uniformidade e os ângulos de junção não diferiram nos solos estudados. 
As anomalias constatadas nos dois padrões de dre nagem revelaram principalmente modificações de condições tono gráficas, além de refletir inclusão de outro tipo de solo, con forme foi observado na unidade Solos Podzólico Vermelho-Amare lo - var. Laras.

Os resultados analisados, de maneira geral, con cordam com os obtidos por FRANÇA (1968), VASOUES FILHO

e KOFFLER (1976), na caracterização de Solos Podzólicos Verme lho-Amarelos.

\subsubsection{Características quantitativas}

A caracterização quantitativa foi efetuada pelas análises dos índices densidade de drenagem, frequência de rios, razão de textura, extensão do percurso superificial e coefi ciente de manutenção, determinados em bacias hidrơráficas e em amostras circulares.

As amostras circulares das redes de drenaqem das unidades de solos estudadas são apresentadas nas fiquras 10 a 13.

Os resultados da análise das características de terminadas em bacias hidrográficas e em amostras circulares são, respectivamente, apresentados nos quadros 12 e 13. As clas ses de textura topográfica são mostradas no quadro 14 e a anạ lise de variância é apresentada nos quadros 15 a 21, sendo que 
nos quadros 18 e 20 são mostrados os desdobramentos da intera Ção solos/amostragem dos índices razão de textura e extensão do percurso superficial.

A densidade de drenagem exibiu diferenças signi ficativas a nível de $1 \%$, revelando sua alta significação para diferenciar solos. Os valores de F, referentes à amostragem e interação solos/amostragem, revelam a equivalência dos siste mas de amostragem utilizados. O seu coeficiente de variacão foi classificado como médio, indicando certa homogeneidade dos dados observados. Estes resultados, de maneira geral, estão em conformidade com os de diversos pesquisadores, como FRANCA (1968), FADEL (1972) e FREIRE (1977). Os valores mais altos na unidade Solos Podzólico Vermelho-Amarelo - var. Laras sugerem que, com o aumento da restrição da drenagem dos perfis,ocorre um maior dissecamento do relevo.

A frequência de rios apresentou diferenças entre solos com menor significação que os dados da densidade de dre nagem. Verificou-se uma grande variação de seus valores dentro da mesma unidade de solo, fato que fora constatado por FRANCA. (1968) e VASQUES FILHO (1972).

Os dados de densidade de drenagem e frenuência de rios confirmam a constatação de ESPINDnL (1978) sobre a concentração de valores mais altos nos solos oue apresentam me nor relação infiltração/deflúvio, seja esta decorrente da nre sença de materiais mais finos ou de uma maior associação com 
96.

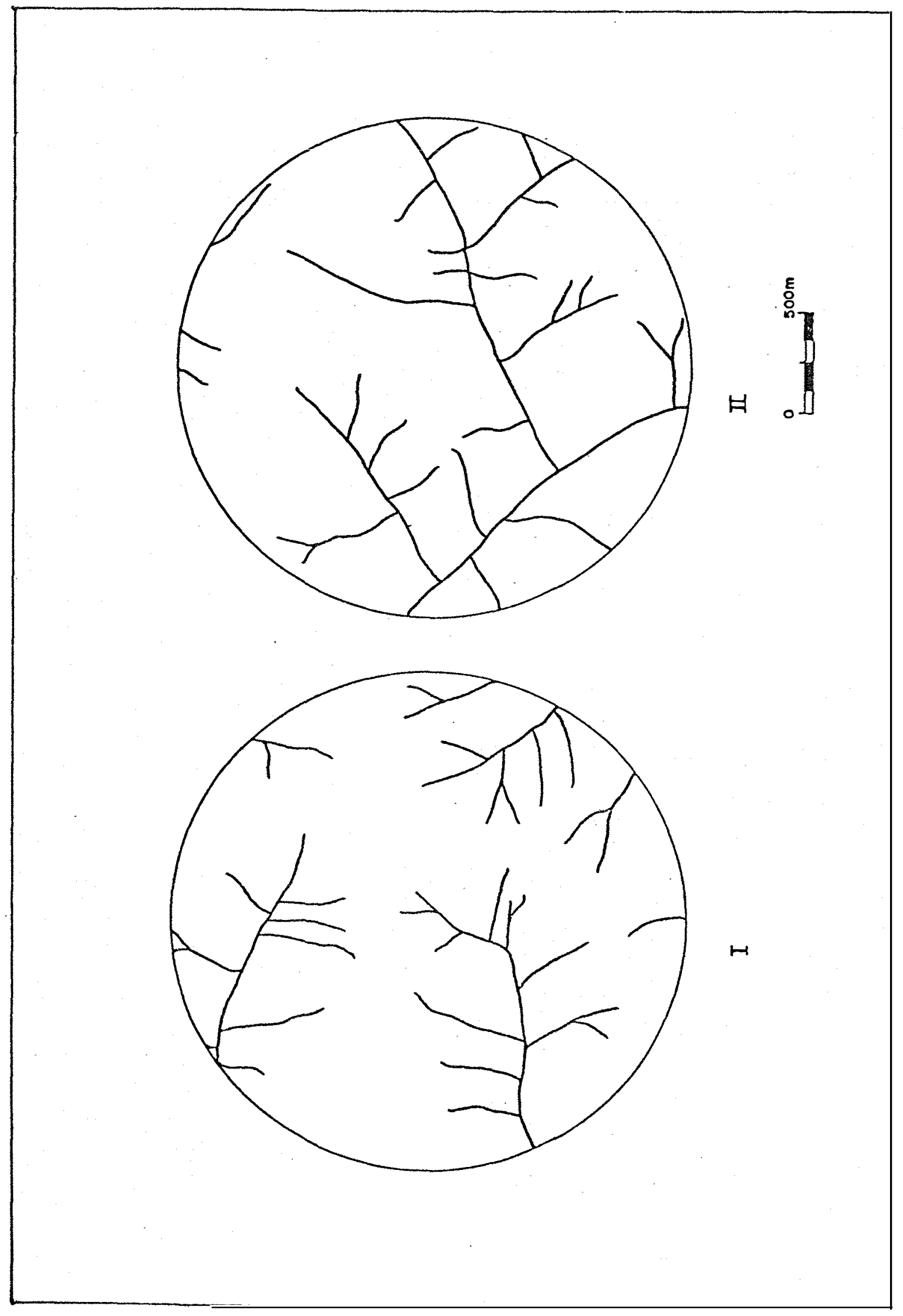

ช

$n$
0
0
0
0
-1
-1
0
$N$
0
0
0
0
0
0
0
0

ఠ

ช

ণ

$\xi$

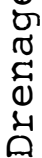

ชี

ه

శ

i म

मे

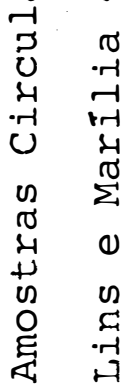

I

욱

喾 


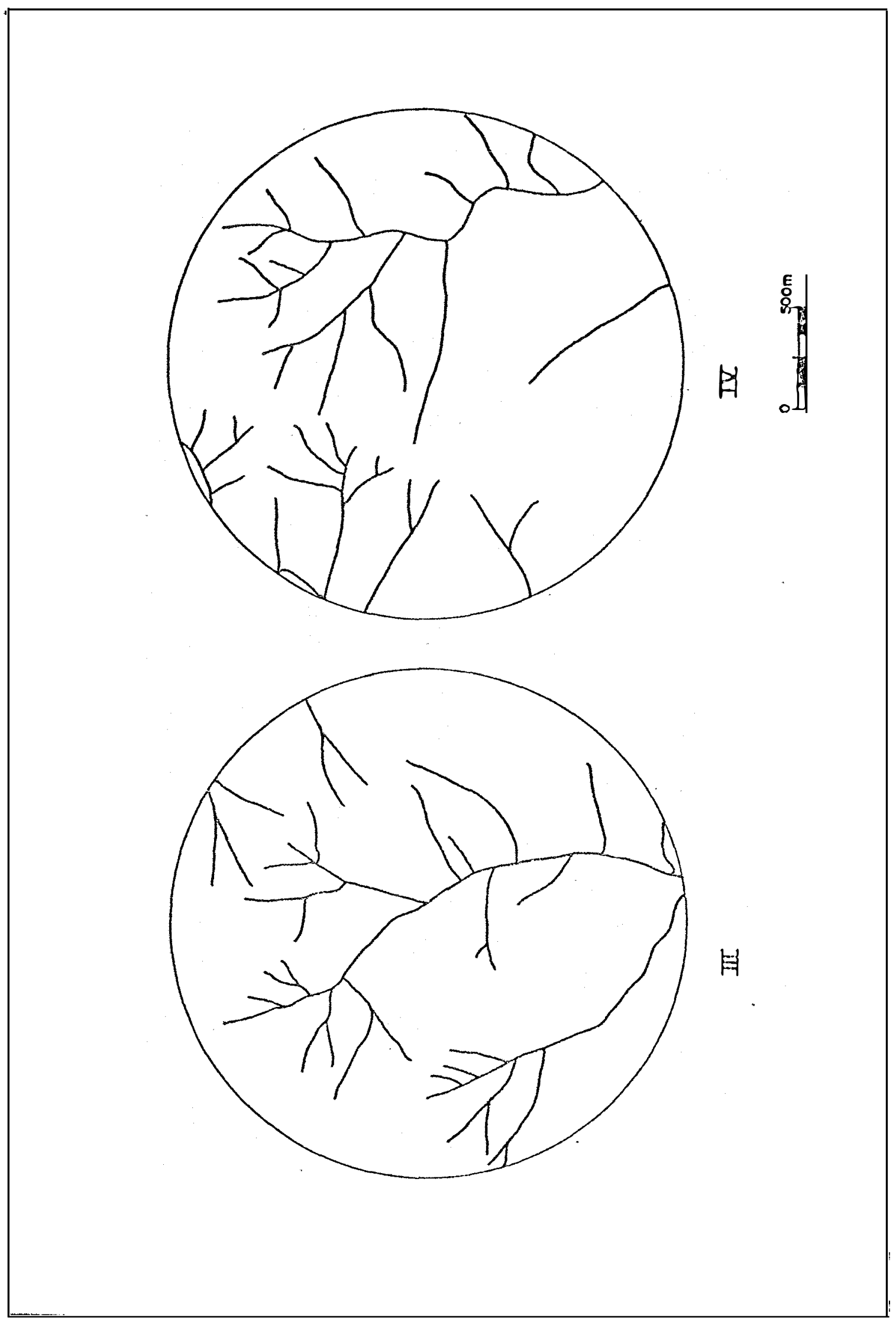


98.

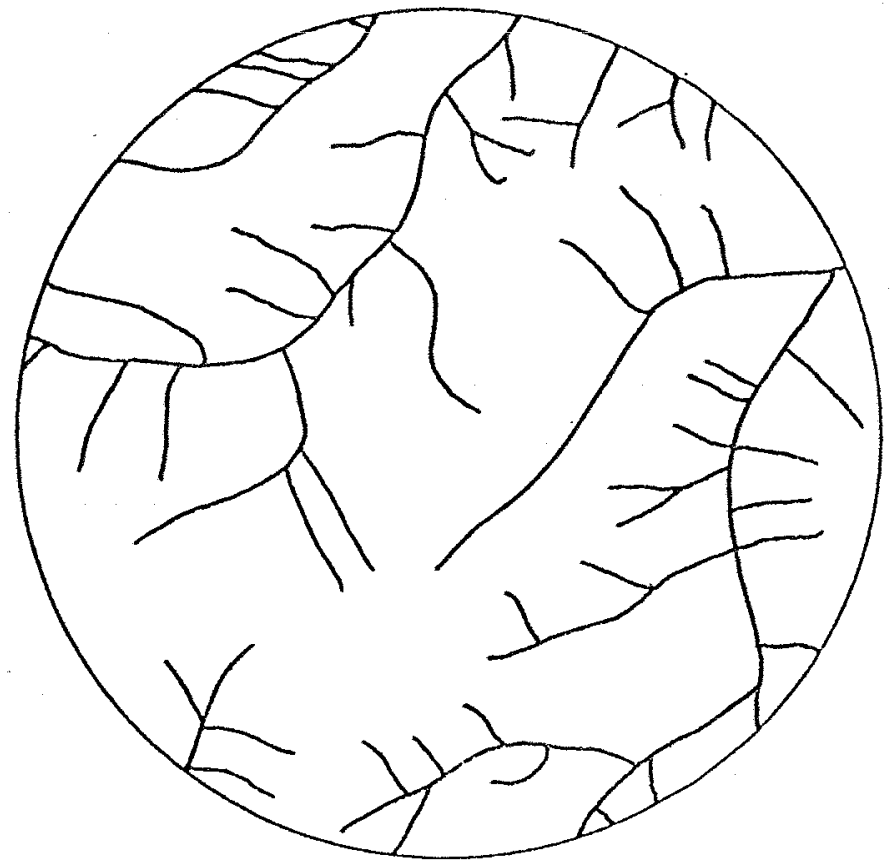

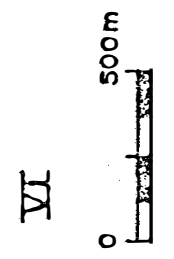

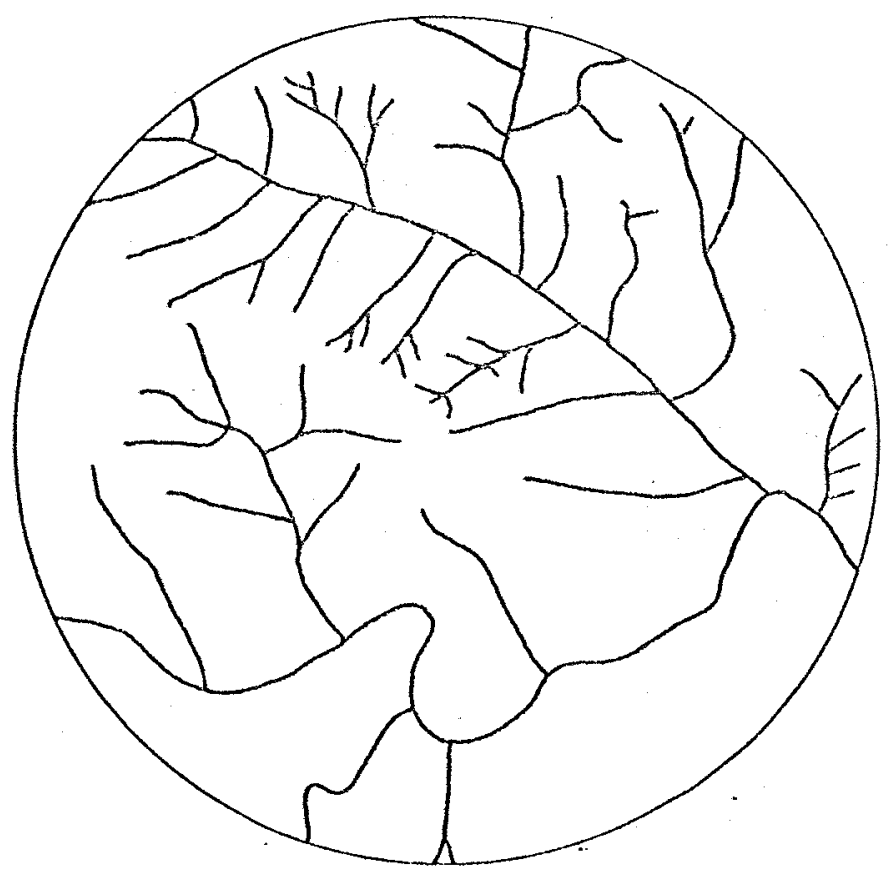

$H$

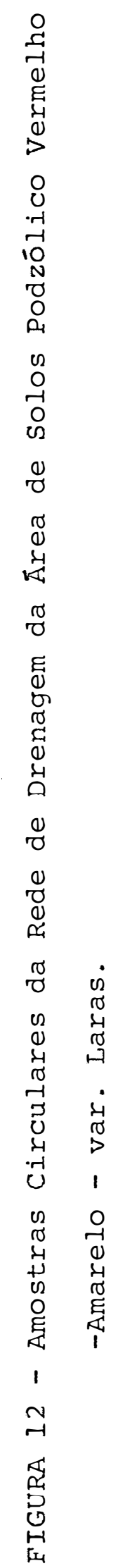




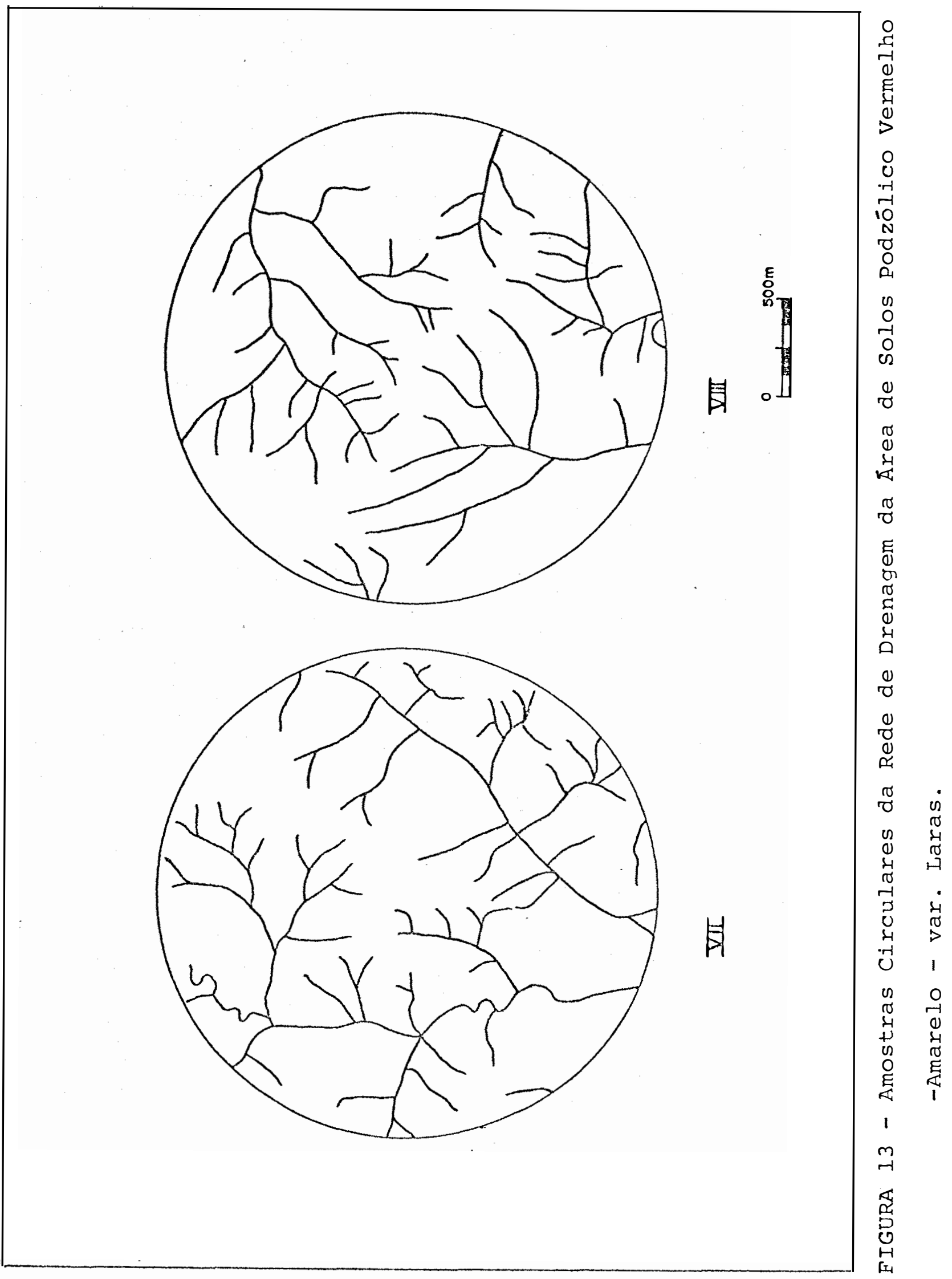




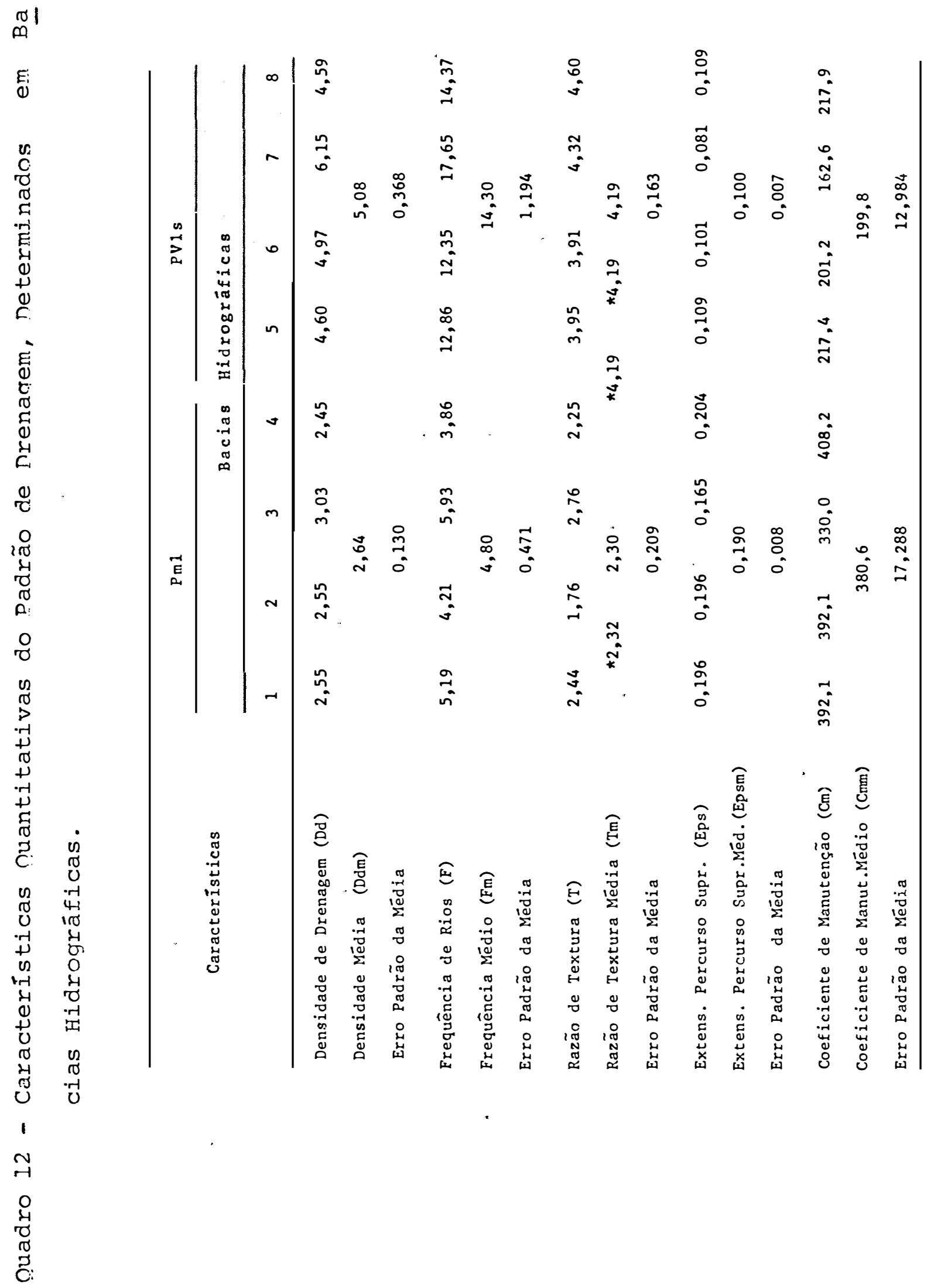




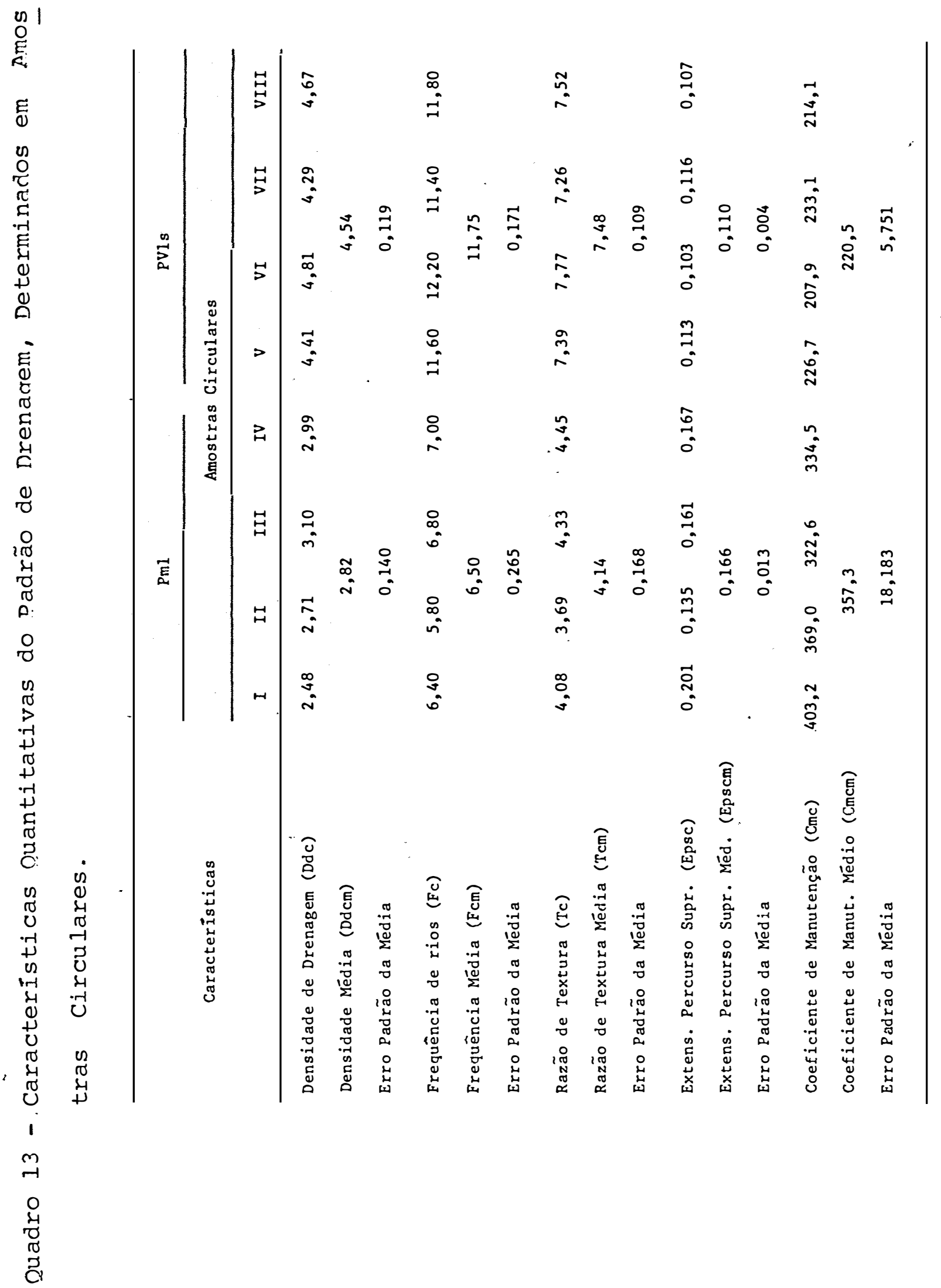


Quadro 14 - Classes de Textura Topográfica dos Padrões de Drena gem.

Unidade de Solos Bacias Hidrográficas Amostras Circulares

Solos Podzolizados

de Lins e Marília

Grosseira

Média

-var. Marília-

Solos Podzólicos

Vermelho-Amarelos

Média

Fina

- var. Laras -

Quadro 15 - Análise de Variância da Característica Densidade de Drenagem .

\begin{tabular}{lcccc}
\hline Causas de Variação & G.L. & S.Q. & Q.M. & F. \\
Solos (S) & 1 & 17,2848 & - & $92,78 * *$ \\
Amostragem (A) & 1 & 0,1279 & - & $0,69^{\mathrm{ns}}$ \\
Amostragem x Solos & 1 & 0,5004 & - & $2,69^{\mathrm{ns}}$ \\
\hline Tratamentos & $(3)$ & $(17,9131)$ & & \\
Resíduo & 12 & 2,2360 & 0,1863 & \\
Total & 15 & & \\
C.V. & $11,45 \%$ \\
\hline
\end{tabular}

ns=não significativo; *=significativo a nível de $5 \%$ e **=signi ficativo a nível de $1 \%$ 
Quadro 17 - Análise de Variância da Característica Frequência de Rios.

\begin{tabular}{lcrrr} 
Causas de Variação & G.L. & S.Q. & Q.M. & F. \\
\hline Solos (S) & 1 & 217,0413 & - & $10,12 * *$ \\
Amostragem (A) & 1 & 0,6972 & - & $0,03^{\mathrm{ns}}$ \\
Amostragem x Solos & 1 & 18,5446 & - & $0,86^{\mathrm{ns}}$ \\
\hline Tratamentos & $(3)$ & $(236,2832)$ & - & \\
Residuo & 12 & 257,2860 & 21,44 & \\
Total & 15 & & & \\
C.V. & $49,57 \%$ & &
\end{tabular}

Quadro 16 - Análise de Variância da Característica Razão de Tex tura.

\begin{tabular}{lcccr}
\hline Causas de Variação & G.L. & S.Q. & Q.M. & \multicolumn{1}{c}{ F. } \\
\hline Solos (S) & 1 & 27,4776 & - & $248,67 * *$ \\
Amostragem (A) & 1 & 26,2656 & - & $237,70 * *$ \\
Amostragem x Solos & 1 & 2,09702 & - & $18,98 * *$ \\
\hline Tratamentos & $(3)$ & $(55,8402)$ & - & \\
Résíduo & 12 & 1,3266 & 0,1105 & \\
\hline Total & 15 & & & \\
C.V. & $7,33 \%$ & & & \\
\hline
\end{tabular}


Quadro 18 - Desdobramento da Interação Solos/Amostragem da racteristica Razão de Textura.

\begin{tabular}{lcccc}
\hline Causas de Variação & G.L. & S.Q. & Q.M. & F. \\
\hline Solos d/Amost.bac.hid. & 1 & 7,1630 & - & $64,82 * *$ \\
Solos d/Amost.am.circ. & 1 & 22,4050 & - & $202,76 * *$ \\
Amost.d/Solos Pml & 1 & 6,7345 & - & $60,94 * *$ \\
Amost.d/Solos PVls & 1 & 21,6482 & - & $195,91 * *$ \\
\hline
\end{tabular}

Quadro 19 - Anālise de Variância da Característica Extensão do Percurso Superficial.

\begin{tabular}{lcccc}
\hline Causas de Variação & G.L. & S.Q. & Q.M. & F. \\
\hline Solos (S) & 1 & 0,022 & - & $275,00 * *$ \\
Amostragem (A) & 1 & 0,0006 & - & $7,81 *$ \\
Amost. x Solos & 1 & 0,001 & - & $12,50 * *$ \\
\hline Tratamentos & $(3)$ & 0,023 & & \\
Residuo & 12 & 0,001 & 0,00008 & \\
\hline Total & 15 & & \\
C'. & $1,98 \%$ & & \\
\hline
\end{tabular}


Quadro 20 - Desdobramento da Interação Solos/Amostragem da racterística Extensão do Percurso Superficial.

\begin{tabular}{lcccc}
\hline Causas de Variação & G.L. & S.Q. & Q.M. & F. \\
\hline Solos d/Amost.bac.hid. & 1 & 0,017 & - & $212,50 * *$ \\
Solos d/Amost.am.circ. & 1 & 0,020 & - & $250,00 * *$ \\
Amost. d/Solos Pml & 1 & 0,077 & - & $962,50 * *$ \\
Amost. d/Solos PVls & 1 & $-0,016$ & - & $-200,00 * *$ \\
\hline
\end{tabular}

Quadro 21 - Anālise de Variância da Característica Coeficiente de Manutenção.

\begin{tabular}{|c|c|c|c|c|}
\hline Causas de Variação & G.L. & $S \cdot Q$. & Q.M. & $F$. \\
\hline Solos (S) & 1 & 106732,9 & - & $93,04 * *$ \\
\hline Amostragem (A) & 1 & 41,0 & - & $0,03^{\text {ns }}$ \\
\hline Amost. $x$ Solos & 1 & 2260,8 & - & $1,97^{\mathrm{ns}}$ \\
\hline Tratamentos & (3) & 109434,7 & - & \\
\hline Resíduo & 12 & 13756,2 & 1147,1 & \\
\hline Total & 15 & & & \\
\hline C.V. & $11,78 \%$ & & & \\
\hline
\end{tabular}


Litossolos. A verificação de que estes índices foram indiví dualmente eficientes para a diferenciação dos solos diverre de HORTON (1945), que observou a necessidade de considerá-los con juntamente e de FRANÇA (1968) e VASก̣UES FILHO (1972).

A razão de textura apresentou valores de $F$ mui to altos, revelando sua significação na diferenciação de solos. Os:valores de $\mathrm{F}$, referentes à amostragem e interação solos/ /amostragem, permitiram estabelecer que a determinação deste Indice deve ser feita conjuntamente pelos dois sistemas de amostragem, fato confirmado pelo desdobramento da inte ração solo/amostragem. A verificação de sua estabilidade den tro do padrão de drenagem está em divergência com FRANC̣A (1968).

As classes de textura topográfica foram diferen tes em função dos solos e do sistema de amostragem utilizado, corroborando com os dados de FREIRE (1977).

A comparação global entre esses três elementos do padrão de drenagem indicou que, em termos de distinção de solos, a maior eficiência foi ap̣resentada pela razão de textu ra e a menor, pela frequência de rios, o que diverge de FRANCA (1968), MARCHETTI (1969), FADEL (1972) e VAS?UUES FILHO (1972), que encontraram a maior eficiência da densidade de drenangem e de FREIRE (1977), que obteve dados não significativos. Os valo res obtidos, de maneira geral, se enquadram dentro dos determi nados para os solos podzólicos Vermelho-Amarelos referidos por FRANÇA (1968), MARCHETTI (1969), VASOQUES FILHO (1972) e ES 
PINDOLA E GARCIA (1978).

Particularizando, os dados da unidade Solos pod zolizados de Lins e Marília - var. Marília, obtidos em amos tras circulares, apresentam valores médios ligeiramente infe riores aos obtidos por KOFFLER (1976) e os da unidade Solos Podzólico Vermelho-Amarelo - var. Laras são semelhantes aos obtidos por MARCHETTI (1969) e VASONUES FILHO (1972).

A extensão do percurso superficial exibiu dados que revelam ser, dos índices analisados, o mais eficiente na caracterização do padrão de drenagem com o propósito de dife renciar os solos estudados. Apresentou-se como o elemento mais estável do padrão de drenagem, conforme mostram os valores do coeficiente de variação. O desdobramento da interação solos/ /amostragem revelou a maior eficiência do critério de amostras circulares na diferenciação das unidạdes de solos.

O coeficiente de manutenção apresentou comportạ mento similar aos da densidade de drenagem e frequência derios, sendo eficaz na diferenciação de solos, independentemente do critério de amostragem. Este indice, por retratar a área de drenagem que mantém um metro linear de canal escoadouro e pe los dados observados, revelou-se de alta importância na dife renciação das condições de drenagem das formações sup̣erficiais.

Pelos dados da análise de variância constatou-se que, em termos de eficiência para diferenciar solos, os índi 
ces analisados se apresentam na seguinte ordem decrescente: ex tensão do percurso superficial, razão de textura, coeficiente de manutenção, densidade de drenagem e frequência de rios. Os valores dos coeficientes de variação indicam que a sequência, extensão do percurso superficial, rảzão de textura, densidade de drenagem, coeficiente de manutenção e frequência de rios, representa a ordem crescente de variação dos elementos dentro da unidade de solo.

Os resultados obtidos mostraram, de maneira ge ral, a maior adequabilidade das amostras circulares na caracte rização do padrão de drenagem, corroborando com os resultados de FRANÇA (1968), FADEL (1972), VAS@UES FILHO (1972), GEVAERD (1974) e CARVALHO (1977).

Numa análise global pode-se estabelecer oue a cạ racterização quantitativa do pađrão de drenagem permitju, de maneira bastante eficiente, a diferenciação das áreas de ocor rência de solos apresentando distintas condições de drenagem dos perfís. A caracterização quantitativa do padrão revelou di ferenças das redes de drenagem associadas às diversidades do movimento superficial da água, refletindo condições de deflū vio, infiltração, permeabilidade e resistência dos materiais à erosão. Estes resultados confirmam HORTON (1945), SMITH (1950)， LUEDER (1959)，FROST (1960)，RAY e FISCHER (1960)， 7IN KE (1960), RAY (1963) e RICCI e PETRI (1965). O estabelecjmen to de inferências específicas sobre os solos foi possível nor 
que as bacias e amostras circulares, empregadas na amostragem, foram de tamanho adequado e representativas de áreas onde a distribuição dos solos estava bem definida.

5.2.2. Composição da rede de drenagem

A caracterização da composição da rede de drena gem foi estabelecida pela análise dos seguintes elementos: nū meros de segmentos de rios, razão da ramificação, comprimentos totais de segmentos de rios, razão de comprimentos totais, com primentos médios de segmentos de rios e razão de comprimentos médios.

5.2.2.1. Análise da composição de rede de dre nagem determinada em bacias hidroorrá ficas

Número de segmentos de rios.

Os valores determinados para números de seamen tos de rios em cada ordem e total da bacia e os valores calcu lados pelas médias artmética ponderada em relação às áreas das bacias, são apresentados no quadro 22 .

Os números de segmentos de rios apresentaram-se diferentes nos dois solos. As diferenças foram constatadas tan to nos segmentos de $1^{a}$ e e $2^{\text {a }}$. ordem, como nos referentes ao to 


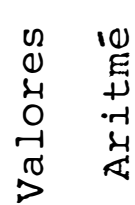

离

( $)$

ช 0

ह

थ

.

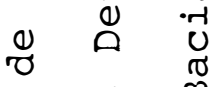

in

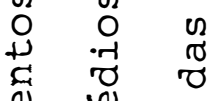

(1) ${ }^{10} 0$

\begin{tabular}{lll}
0 & & 0 \\
0 & 0 & 0 \\
ป & 0 & \multicolumn{1}{c}{}
\end{tabular}

ब

$0 \stackrel{0}{>} 10$

म 0 O 20

点

○

थ

ช

更

岁

थ E D

$\begin{array}{lll}0 & 0 & 0 \\ \sim & 0 & 0\end{array}$

थ

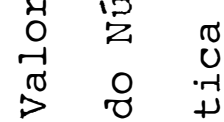

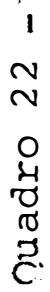

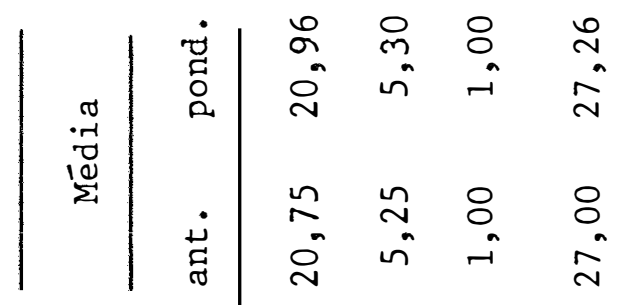

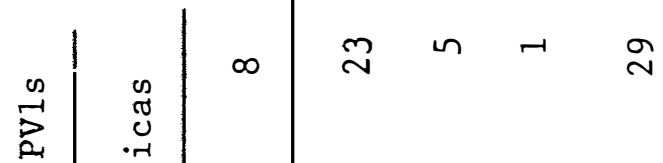

$r \stackrel{-7}{n}+\sqrt{n}$

6 $\begin{array}{llll} & \cdots & \rightarrow & \infty\end{array}$

$\cdot \pi$

荧

$\vec{E}$

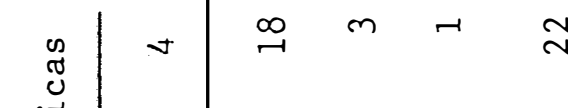

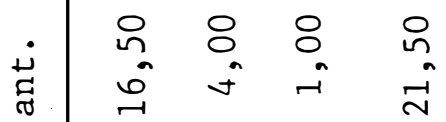

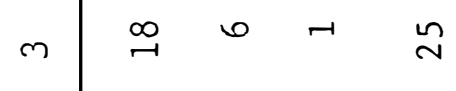

I

$\sim \stackrel{-}{\rightarrow} \rightarrow$

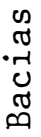

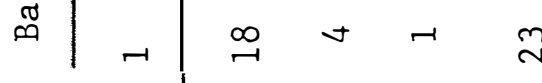

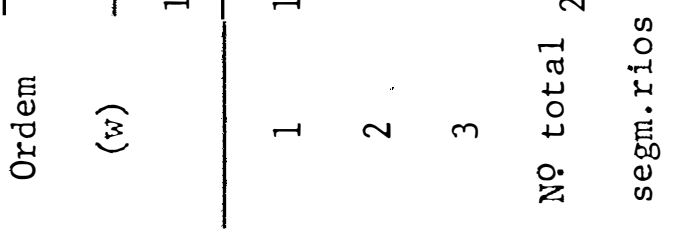


tal da bacia. Os valores calculados pelas médias aritmética e ponderada apresentaram-se próximos, sugerindo a equivalência destes critérios.

A análise de variância indicou que o número to tal de segmentos de rios da bacia apresentou diferenças entre solos com significação estatística a nível de 5\%, revelando a aptidão deste elemento da rede de drenagem na diferenciação de solos, confirmando HORTON (1945), STRAHLER (1957), FRANCA (1968), FADEL (1972) e GALHEGO (1979) e divergindo de FREIRE (1977). Os valores mais altos deste elemento na unidade Solos Podzólico Vermelho- Amarelo - var. Laras sugerem que existe uma relação direta entre os números de segmentos de rios e o desenvolvimento do relevo, fato condicionado pela maior restri ção das condições de drenagem dos perfîs de solos. 0 aumento do número de rios apresentou-se também diretamente relacionado com a maior ocorrência de Solos Litólicos e maior declividade média das bacias, confirmando souza (1975). Foi verificada uma relação inversa entre os números de segmentos de rios e a ra zão infiltração/deflúvio. De maneira geral, os números de sẹ mentos exibiram valores superiores aos citados na literatura para os Solos podzólicos Vermelho-Amarelos.

As formas assumidas pela relação preconizada por MAXWELL (1955), pela substituição numérica dos números de sẹ mentos de rios e os coeficientes de correlação $(r)$ e de deter minação $\left(r^{2}\right)$ e a porcentagem da variação total exp̣licada são 
apresentados no quadro 23 .

Verificou-se, nas duas unidades de solos, um bom ajustamento dos dados à relação preconizada, apresentando - se coeficientes de correlação significativos à nível de 5\%, valo res altos dos coeficientes de determinação e pequena disp̣ersão dos dados. Os dados da unidade Solos Podzolizados de Lins e Ma rília - var. Marília exibiram um melhor ajustamento à relação preconizada, fato que confirma a afirmação de FREIPE (1977) de que $\circ$ aumento dos números de segmentos de rios da bacia difi culta o ajustamento dos dados à relação de Maxwell.

No quadro 24 são agrupados os valores da média ponderada dos números de segmentos de rios em relação às áreas das bacias, os valores calculados em função das relações estą belecidas e os valores determinados segundo a lei de Horton.

Os valores médios determinados pelos critérios referidos, apresentam diferenças pequenas, revelando a equiva lência desses critérios de determinação. Os resultados indicam que a lei dos números de rios de Horton é obedecida nas presen tes condições ambientais. A continuidade de valores mais eleva dos nas três ordens de ramificação, para os dados determinados por um dos critérios de determinação, foi constatada somente na unidade Solos Podzólico Vermelho-Amarelo - var. Laras, ocor rendo para os dados obtidos sequndo a lei de Horton. A esse respeito existem divergências mostradas pelos trabalhos de SOUZA (1975) e FREIRE (1977), que não verificaram qualquer con 


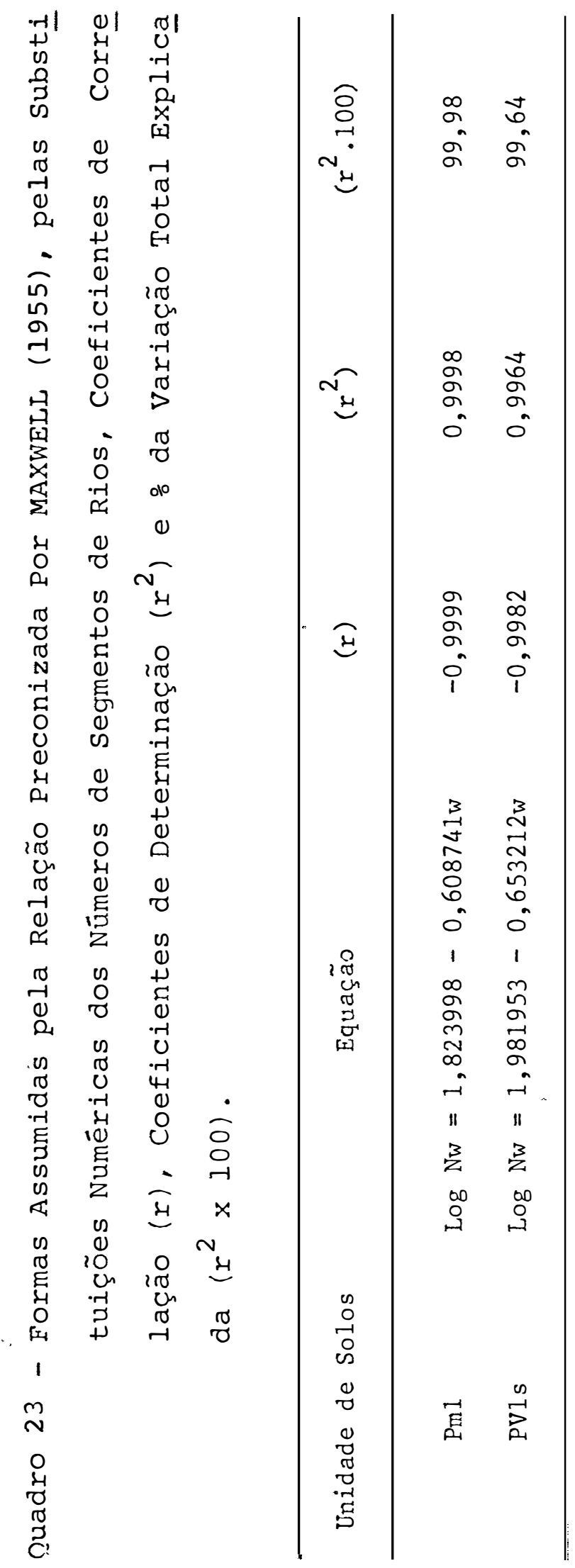




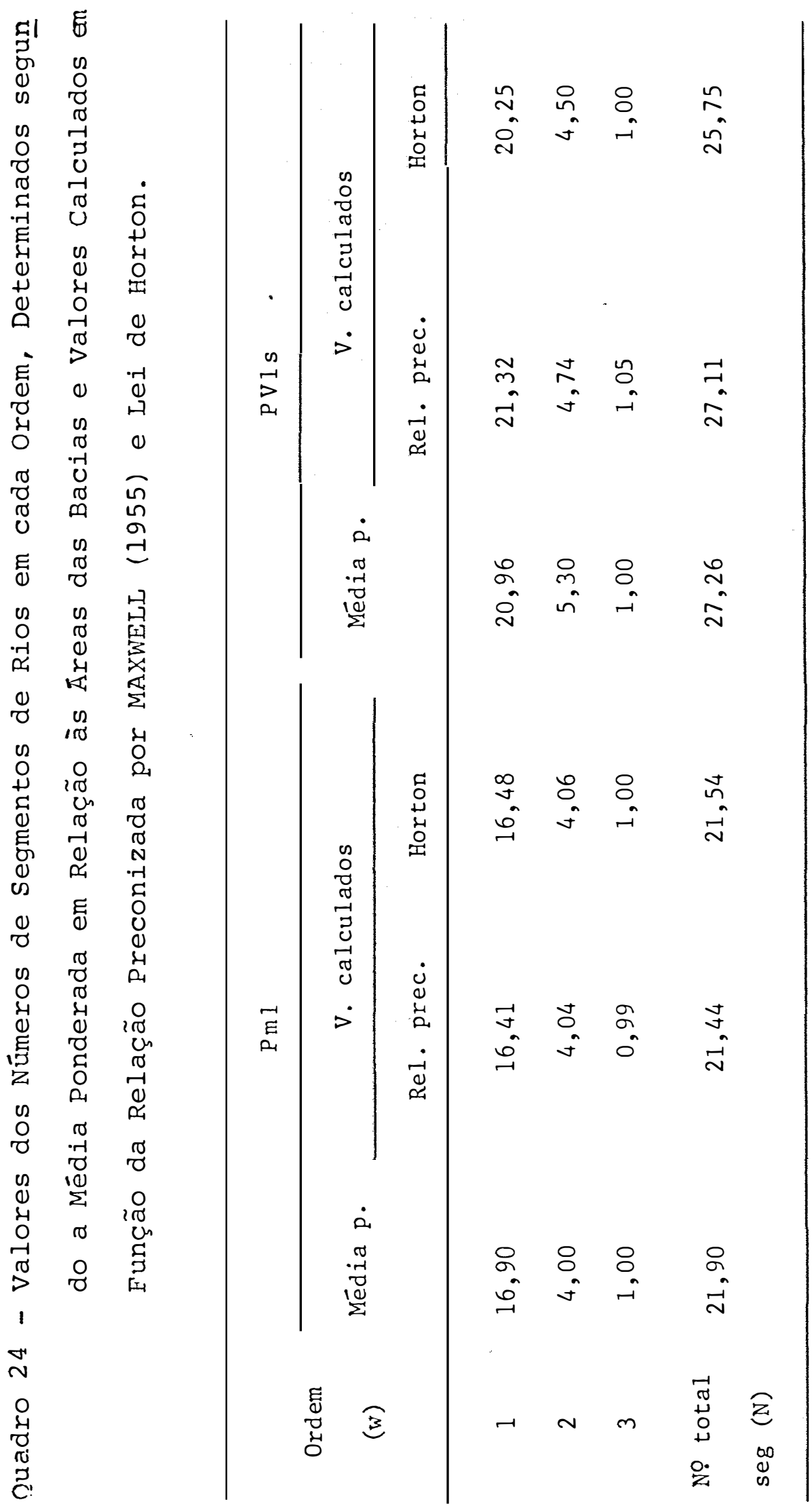


tinuidade de superioridade de valores e pelos trabalhos de HOR TON (1945), MAXWELL (1955), SCHUMM (1956) e FRANCA (1968) aue encontraram continuidade de superioridade de valores, ora nos valores determinados pela lei de Horton, ora pelos da média ponderada.

No quadro 25 são apresentados os valores de ra $z$ ão de ramificação $(\mathrm{Rb})$, onde foram reunidos os valores obse $\underline{\text { }}$ vados e os valores médios determinados pela média aritmética e relação de Maxwell.

A razão de ramificação exibiu diferenças dentro da mesma unidade de solo, revelando-se instável, confirmando referência de STRAHLER (1957). Todavia, os valores médios se apresentam relativamente próximos, mesmo quando comparados en tre solos. A identidade dos valores médios, obtidos pelos crí térios empregados, confirmou a adequabilidade da expressão $\mathrm{Rb}=\operatorname{antilog} \mathrm{b}$, de Maxwell.

Os valores da razão de ramificação não permití ram a diferenciação dos solos, confirmando os resultados de STRAHLER (1957) e divergindo de FRANÇA (1968), FADEL (1972), VASQUES FILHO (1972) e CARVALHO (1977). De maneira geral, os valores observados são relativamente mais altos que os referi dos na literatura para os Solos Podzólicos Vermelho-Amarelos.

\section{Comprimentos totais dos segmentos de rios.}

Os valores observados para os comprimentos totais 


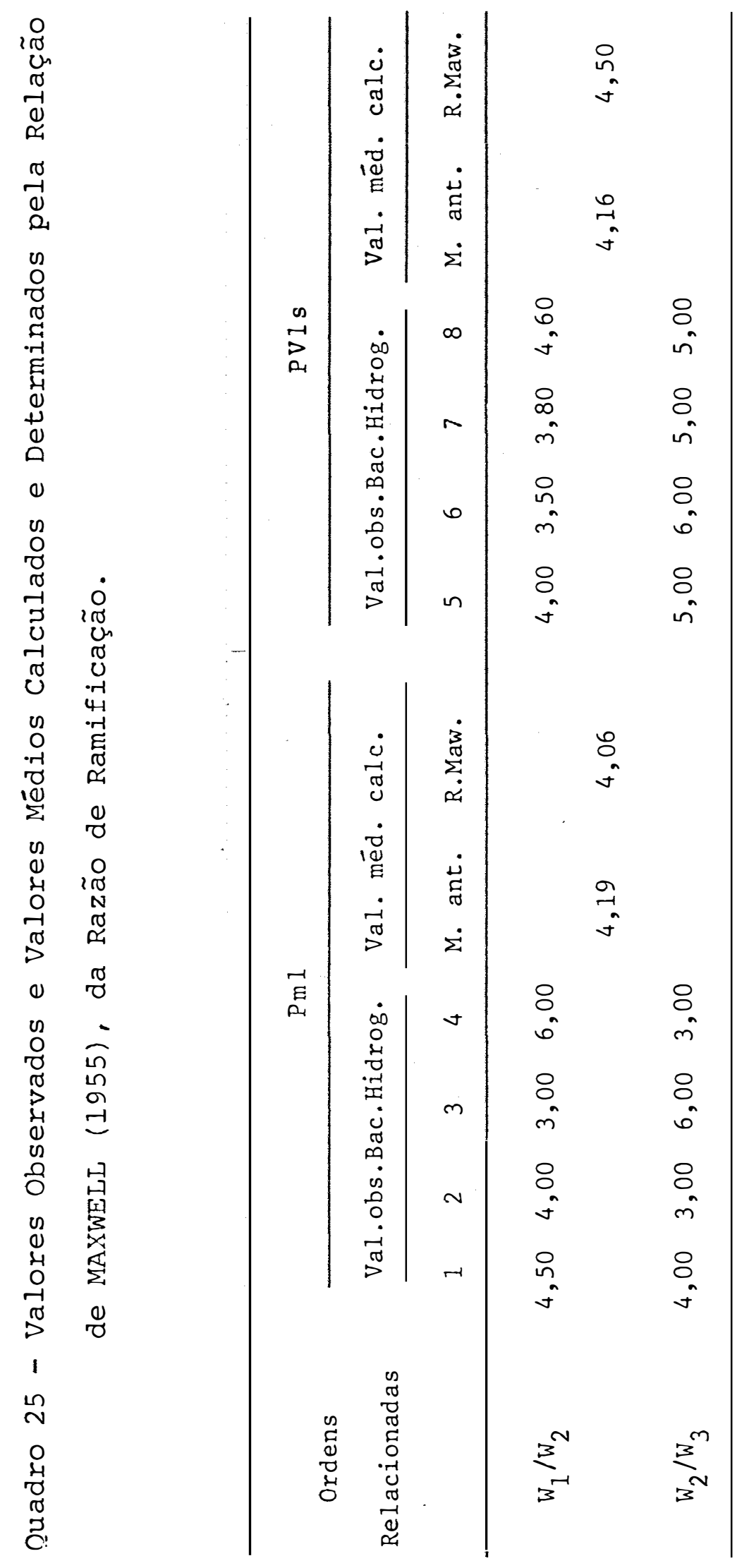


dos segmentos de rios em cada ordem e na bacia e os valores mé dios, determinados pela média ponderada em relação às áreas das bacias, são apresentados no quadro 26 .

Os comprimentos totais dos segmentos de rios mos traram diferenças com pequena significação para a distinçãodos solos, revelando valores que, de maneira geral, diminuem com o aumento da ordem de ramificação. A pequena significação dos comprimentos totais na diferenciação dos solos também foi cons tatada por CARVALHO (1977), o qual considerou que os comprimen tos totais, como dados isolados, não refletem as condições hi drológicas do solo. A verificação da maior variação deste ele mento, dentro da mesma unidade de solo, em relação aos nū meros de segmentos de rios, concorda com as observações de SCHUMM (1956)， STRAHLER (1957)， FRANÇA (1968)， FADEL (1972) e VASQUES FILHO (1972).

Os valores mais altos apresentados pela unidade Solos Podzolizados de Lins e Marília - var. Marília, indicam que os comprimentos totais possuem comportamento inverso ao dos números de segmentos de rios, fato que permite estabelecer que as redes de drenagem serão mais extensas onde os solos pos suem maior relação infiltração/deflúvio, estando em conformi dade com FREIRE (1977).

Os valores obtidos, de maneira geral, são ligei ramente superiores aos citados na literatura para os Solos pod zólicos Vermelho-Amarelos. 


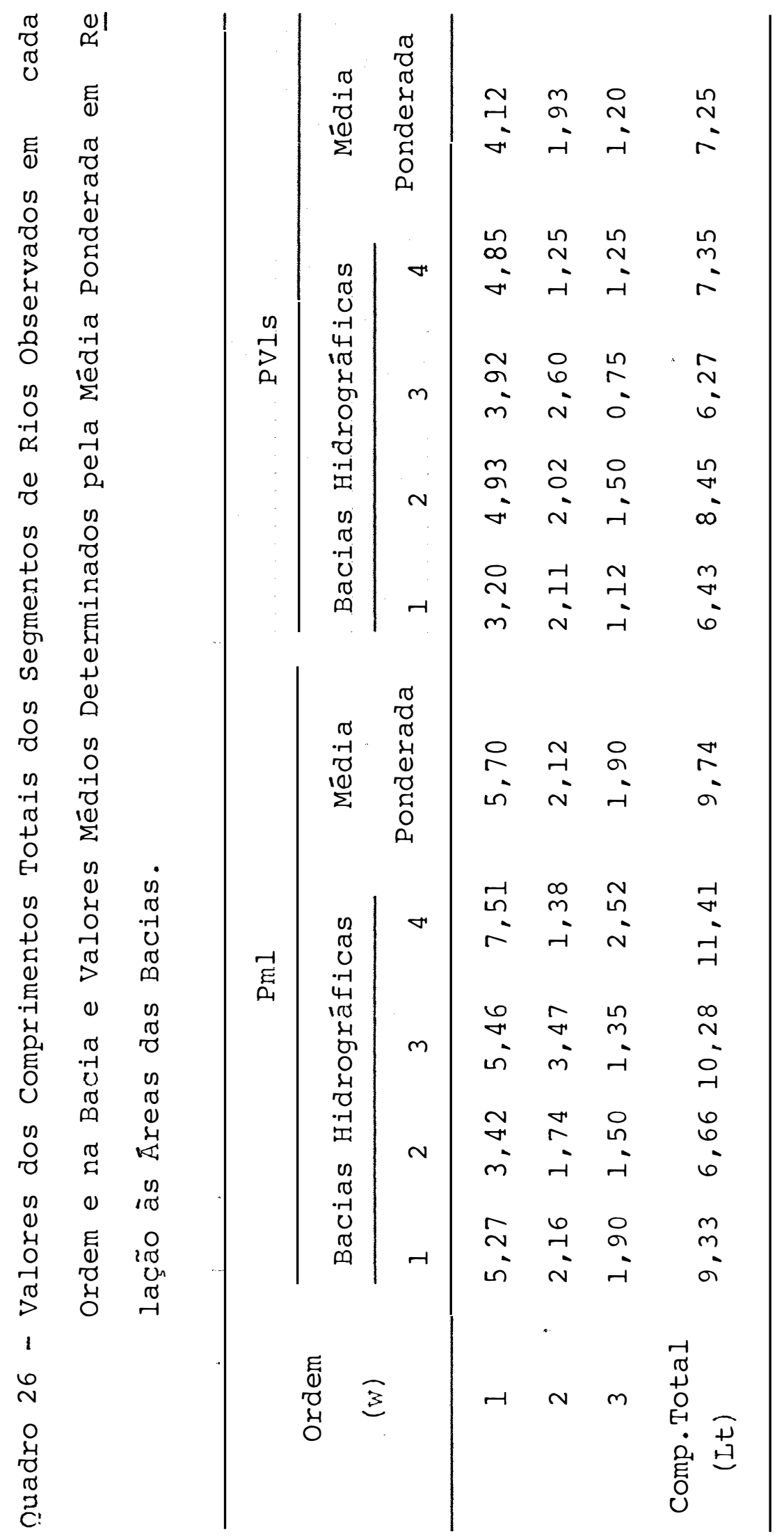


As formas assumidas pelas relações preconizadas por FRANÇA (1968) e STRAHLER (1957), pela substituição numérí ca dos valores obtidos e os valores dos coeficientes de corre lação $(r)$ e de determinação $\left(\dot{r}^{2}\right)$ e a porcentagem de variacão total explicada são apresentadas no quadro 27.

Os dados da unidade Solos Podzolizados de Lins e Marília - var. Marília não apresentaram ajustamento adequado às relações preconizadas e os dados da unidade Solos Podzólicon Vermelho-Amarelo - var. Laras exibiram ajustamento com signi ficação a nível de 5\% de probabilidade e valores dos coeficien tes de correlação praticamente iguais.

Os valores dos coeficientes de correlação dos dạ dos da unidade Solos Podzolizados de Lins e Marília - var. Ma rília, sendo superiores na relação preconizada por STRAHLER. (1957), confirmam as verificações de VASQUUES FILHO (1972) e dí vergem das de FRANCCA (1968) e FADEL (1972).

As diferenças observadas nos valores dos coefi cientes angulares (b) das relações estabelecidas sequndo strah ler, permitem inferências sobre a intensidade da variação dos comprimentos dos segmentos de rios, quando se analisa a passa gem de uma ordem de ramificação para outra, confirmando STRAH LER (1957) .

No quadro 28 são apresentados os valores dos com primentos totais dos segmentos ảe rios, sendo agrupados os va lores da média ponderada em relação às áreas das bacias, os va 


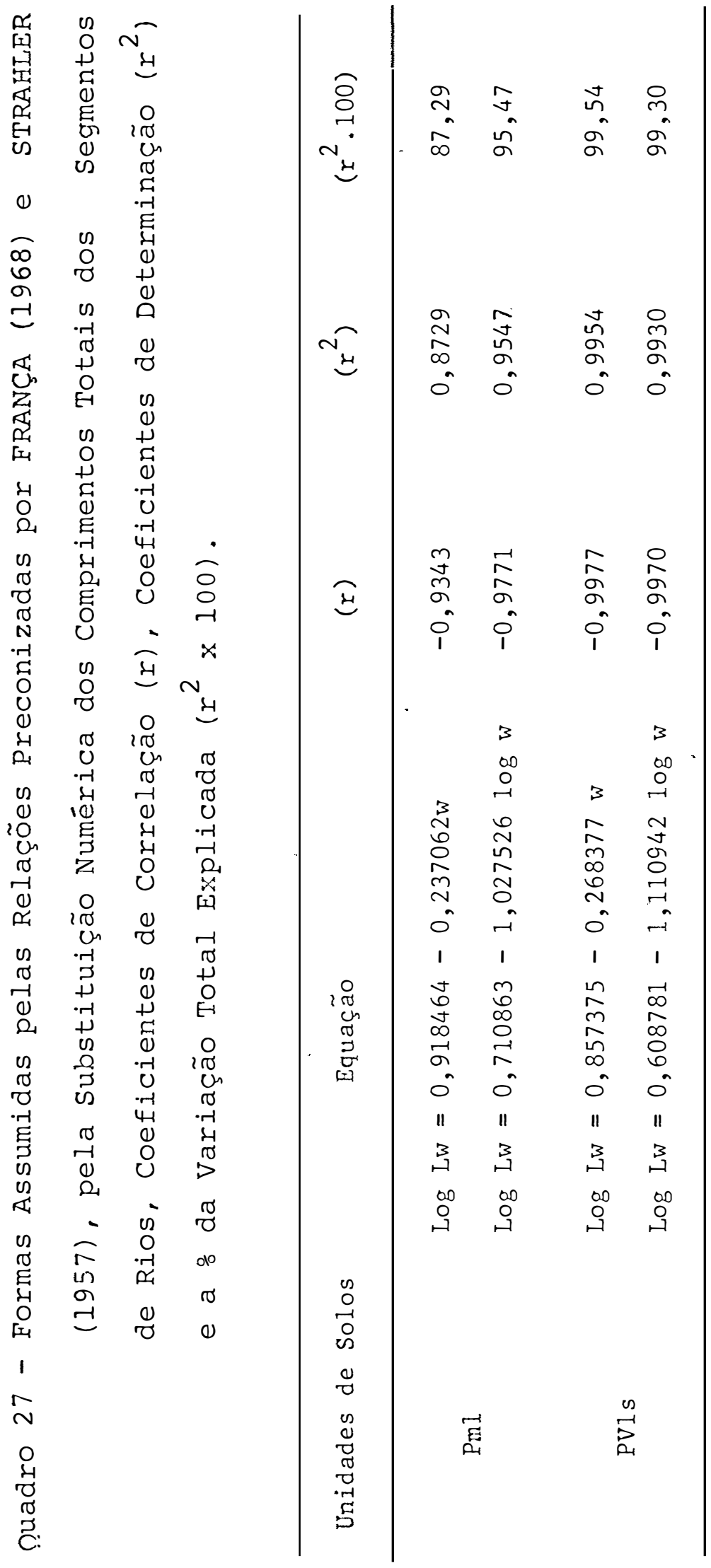




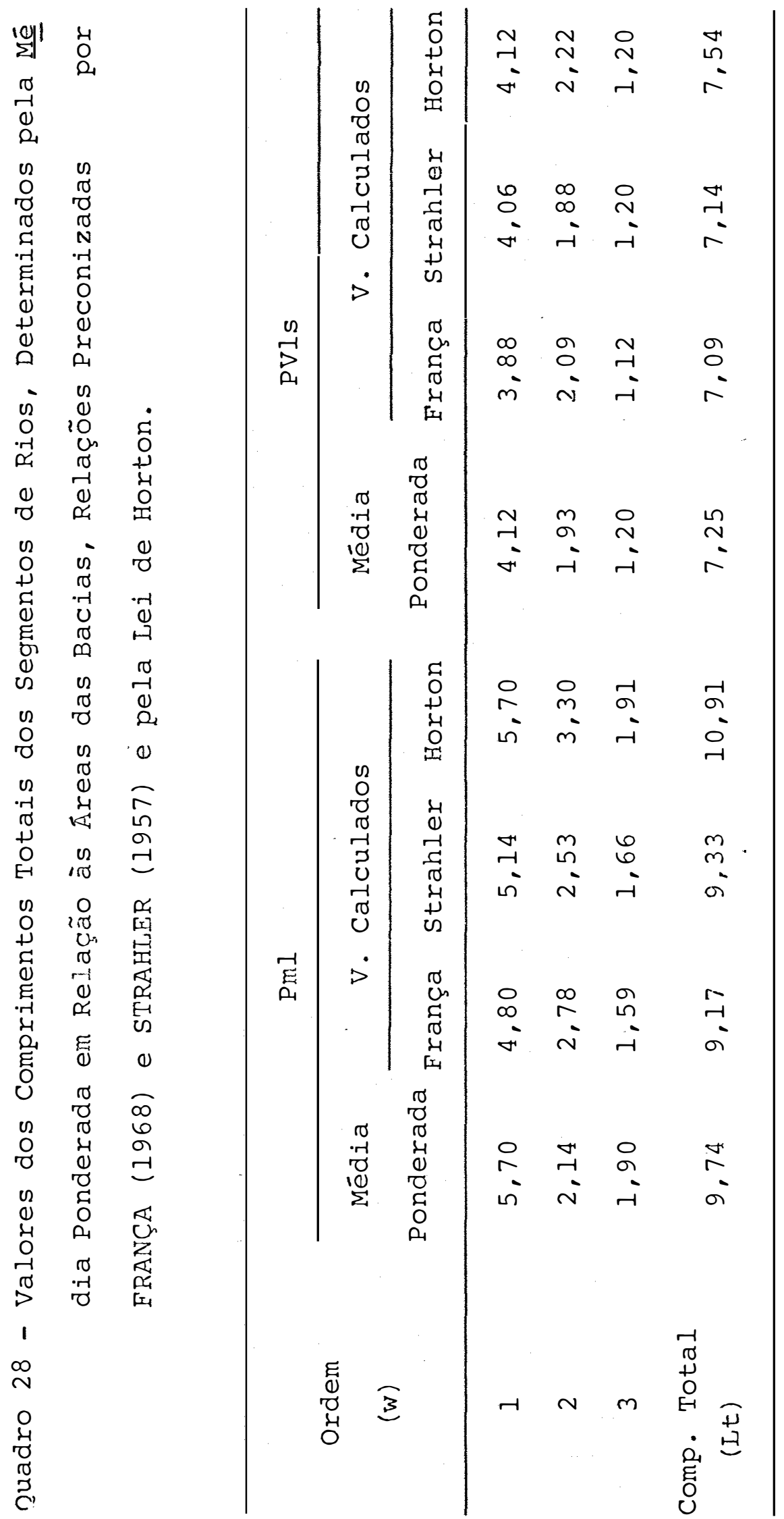


lores calculados em função das formas assumidas pelas relações preconizadas por FRANÇA (1968) e STRAHLER (1957) e os valores calculados segundo a lei de Horton.

Os valores calculados pela média ponderada apre sentaram-se semelhantes aos obtidos pela lei de Horton, indi cando que os comprimentos totais obedecem à lei de Horton nas presentes condições ambientais. A ocorrência, na unidade solos Podzolizados de Lins e Marília - var. Marília, de valores da média ponderada dos comprimentos totais do segmento de rios de 2. ordem inferiores aos determinados pela lei de Horton, pode ser atribuída a efeitos do controle topográfico sobre o desen volvimento da rede de drenagem.

Pela comparação dos valores da média ponderada aos valores calculados segundo as relações preconizadas por França e Strahler, inferiu-se, de maneira geral, um melhor ajustamento dos dados de comprimentos totais à relação de strah ler.

No quadro 29 são apresentados os valores da ra zão de comprimentos totais, sendo reunidos os valores observa dos e os valores médios, determinados pela média aritmética e relação preconizada por FRANÇA (1968).

A razão de comprimentos totais mostrou variacões dentro da mesma unidade de solo, revelando certa instabilidade, provavelmente relacionada aos efeitos dos controles tonográfi 


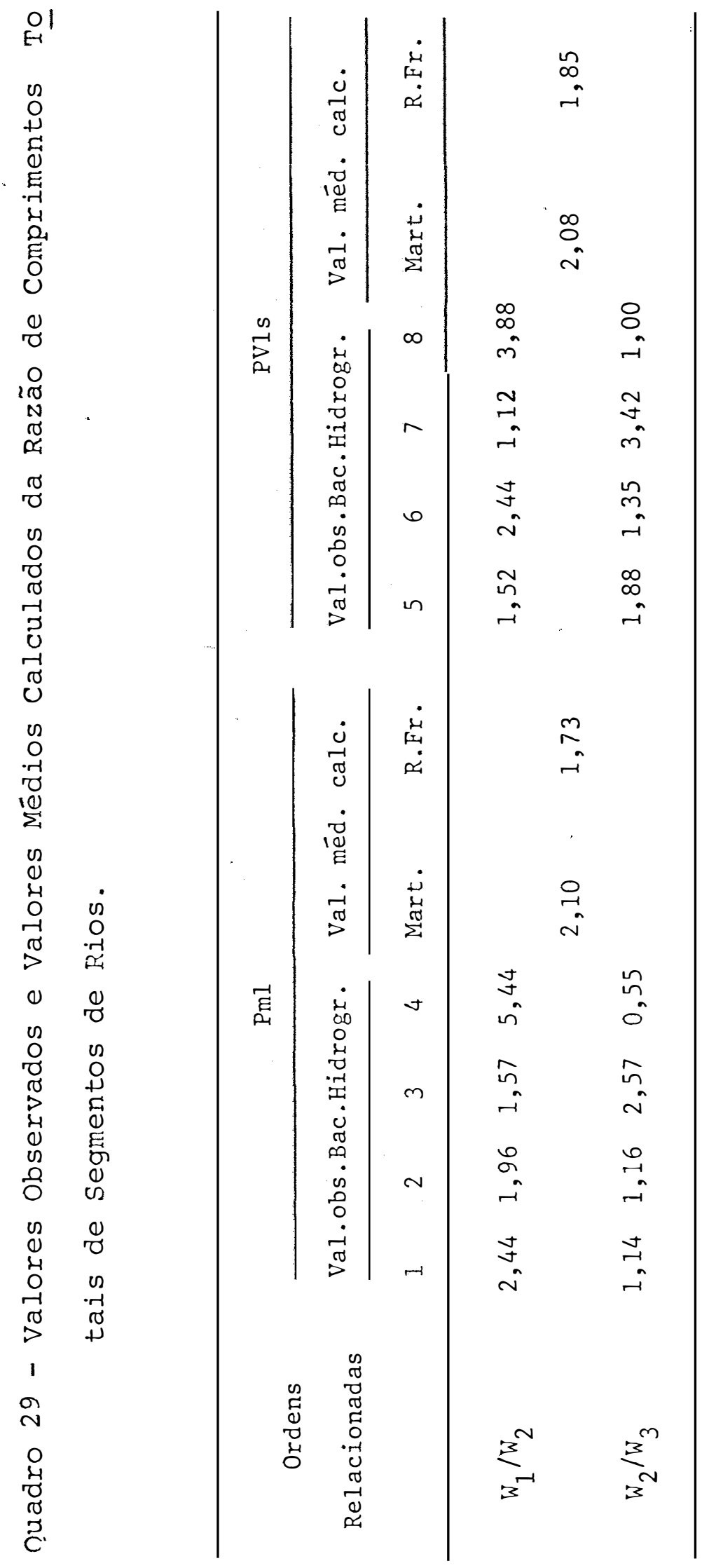


cos e estruturais. Os valores médios apresentados não permití ram diferenciar os solos, o que diverge de FREIRE (1977) e CAR VALHO (1977). De maneira geral, os valores observados se enqua dram dentro dos citados na literatura para os Solos Podzólicos Vermelho-Amarelos.

\section{Comprimentos médios dos segmentos de rios}

Os valores dos comprimentos médios dos segmentos de rios, em cada ordem e bacia e os valores médios, determi nados pela média ponderada em relação às áreas das bacias são apresentados no quadro 30 .

Os comprimentos médios dos segmentos de rios a presentaram diferenças entre solos, tanto para cada ordem de ramificação como para a bacia. Para a bacia, os comprimentos médios exibiram diferenças entre solos significativos a nível. de $1 \%$ de probabilidade, conforme é constatado nelo quadro 36 , relevando a alta significação hidrológica deste elemento da re de de drenagem, o que confirma SCHUMm (1956), STRAHLER (1957), FRANÇA (1968), FADEL (1972) e CARVALHO (1977) e diverge de SOUZA (1975) e FREIRE (1977). Na unidade Solos Podzolizados de Lins e Marília, os comprimentos médios apresentaram valores mais elevados, fato que era esperado porque as redes de drena gem desta unidade de solo apresentam-se mais extensas e menos ramificadas. De maneira geral, os valores observados se enqua dram dentro dos citados na literatura para os Solos Podzólicos Vermelho-Amarelos. 


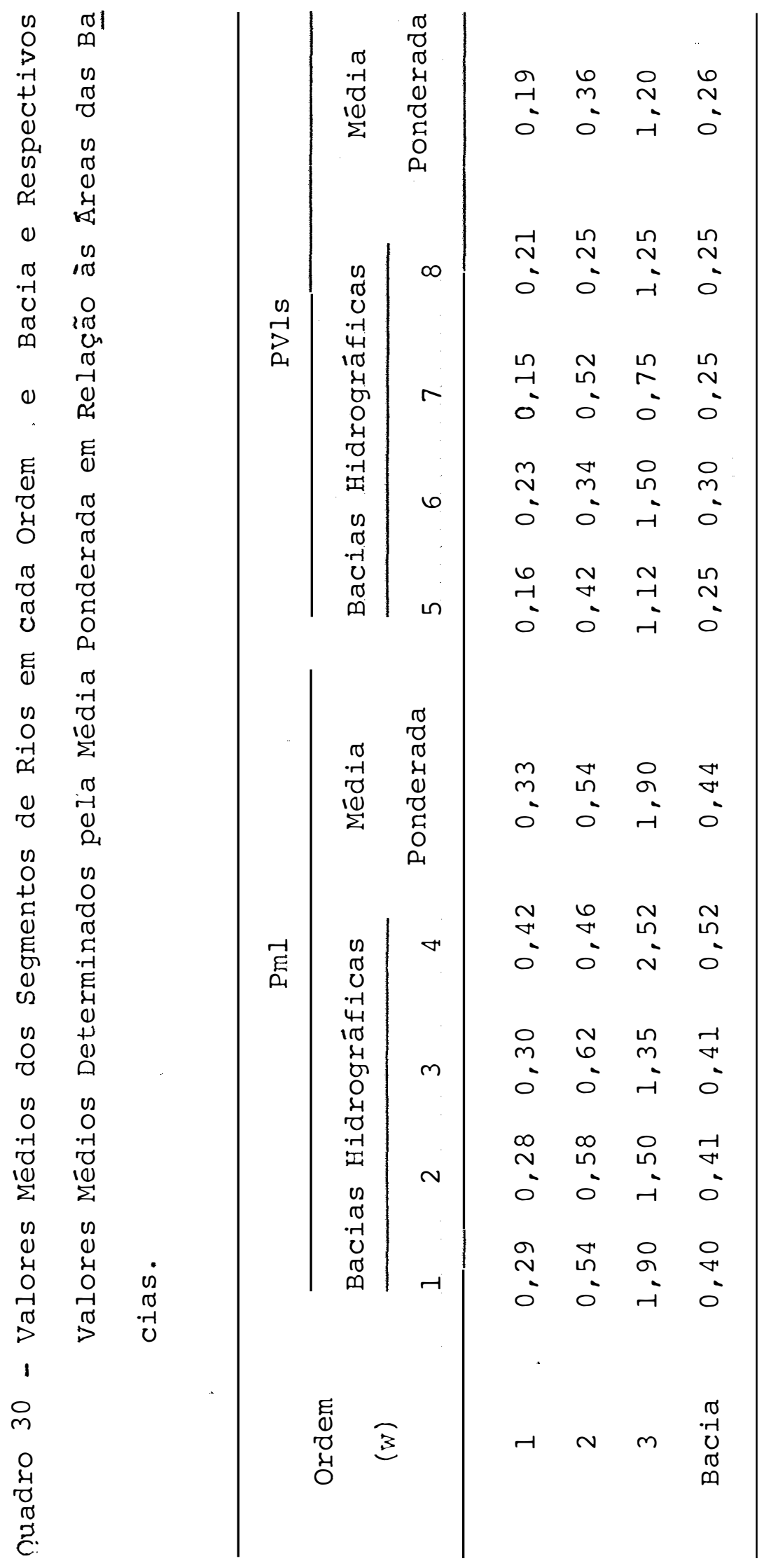


As formas assumidas pela substituição numérica dos dados observados na relação preconizada por VASọUES FILHO (1972) e os coeficientes de correlação $(r)$ e de determinação $\left(r^{2}\right)$ e a porcentagem total da variação exp̣licada são apresenta dos no quadro 31 .

Os valores dos comprimentos médios apresentaram baixo ajustamento à relação preconizada, estando em conformida de com CARVALHO (1977) e FREIRE (1977).

No quadro 32 são agrupados os valores da média ponderada, os valores calculados segundo a relação preconizą da, os valores pela relação $\mathrm{Lw} / \mathrm{Nw} \in$ os valores determinados pẹ la lei de Horton.

Os comprimentos médios, de maneira geral, mostra ram comportamento similar ao dos comprimentos totais, onde os valores determinados pela lei de Horton são os que mais se acercam dos determinados pela média ponderada. Este fato reve lou que os comprimentos médios obedecem a lei de Horton, embo ra seja observado uma menor precisão que a verificada para os nūmeros de rios, confirmando HORTON (1945), STRAHLER (1957), FRANÇA (1968) e outros pesquisadores. Os valores observados dos comprimentos médios dos segmentos de rios de 2 a ordem de ramificação, de maneira semelhante aos comprimentos totais, apresentaram-se inferiores aos calculados pela lei de Horton, fato que também deve estar ligado aos efeitos dos controles to pográficos e estruturais presentes. Verificou-se a equivalên 
127.

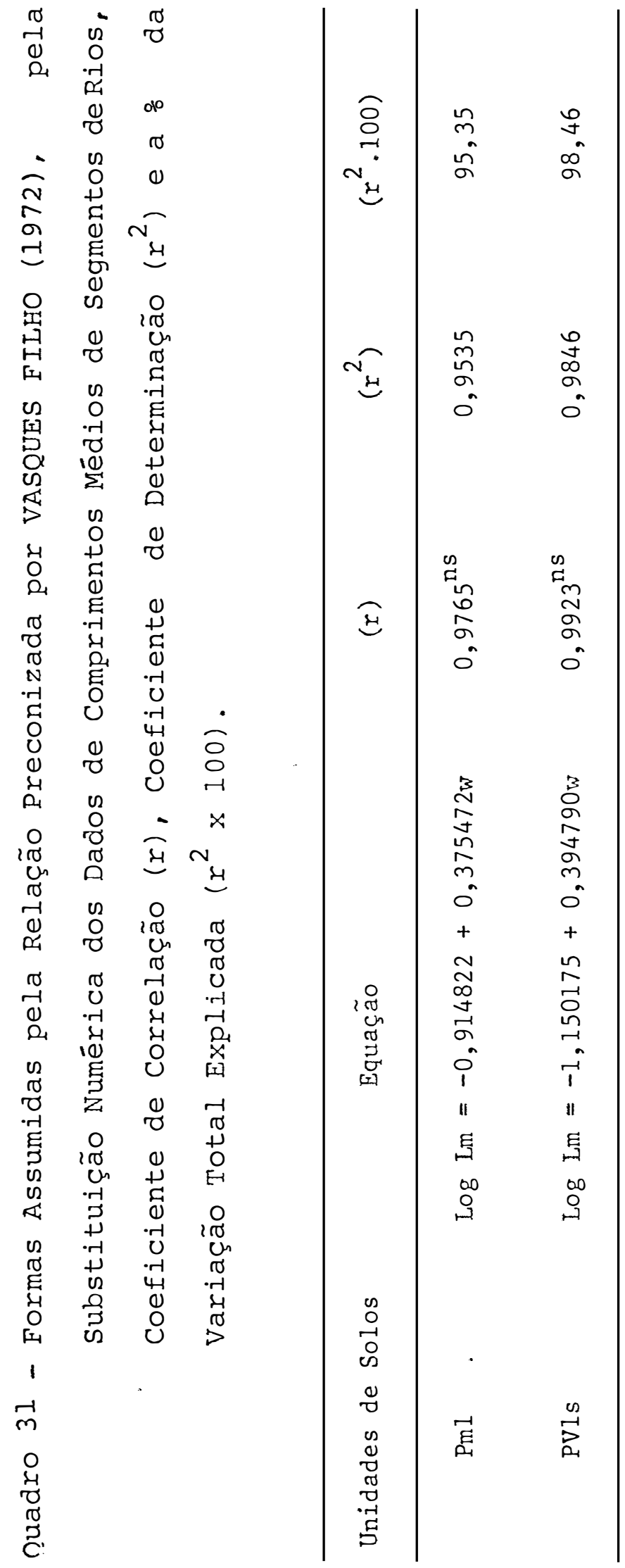




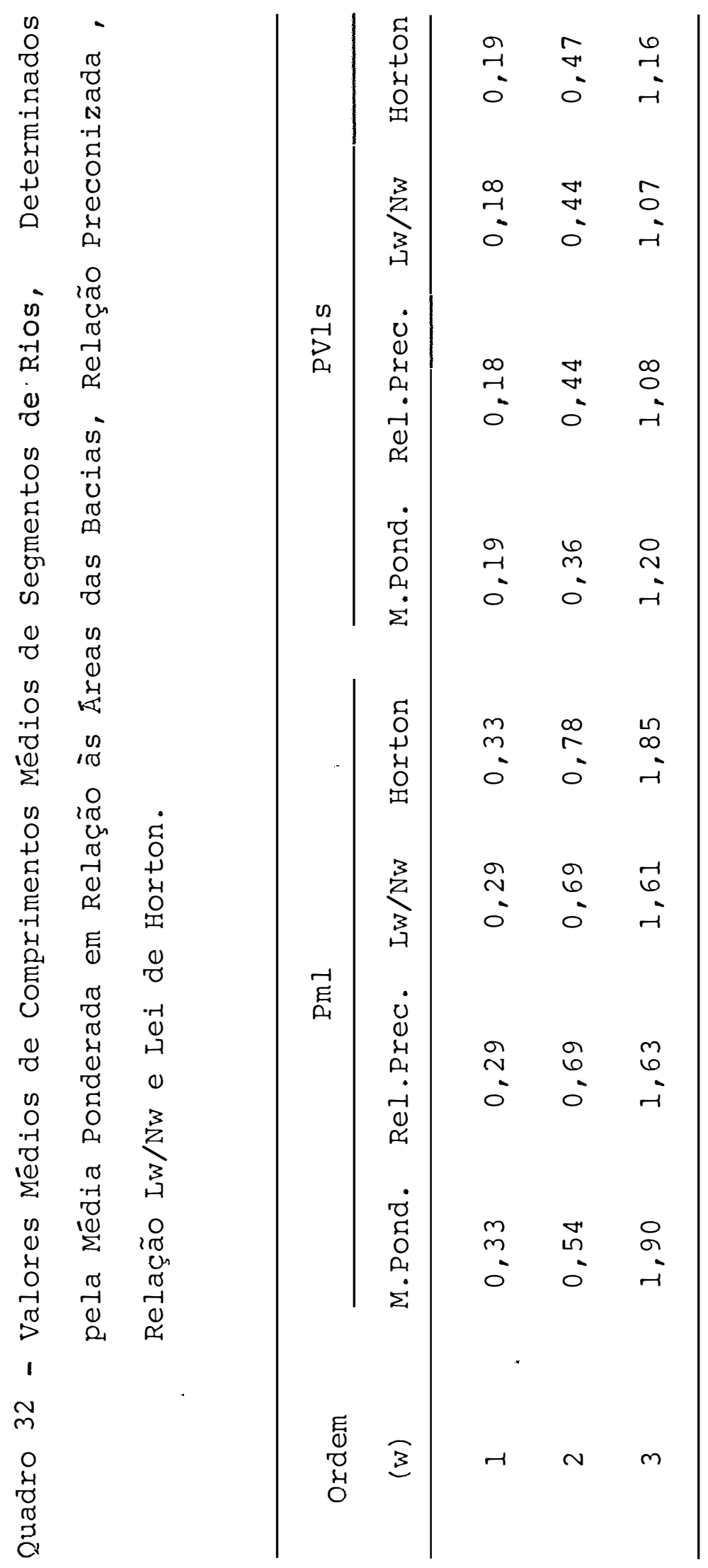


cia dos critérios relação preconizada por VASQUES FILHO (1972) e relação Lw/Nw, de FRANÇA (1968).

Numa análise global, pode-se estabelecer que todos os critérios de determinação dos valores médios dos com primentos médios dos segmentos de rios são eficientes para a diferenci.ação dos solos •

Os valores da razão de comprimentos médios dos segmentos de rios, referentes aos dados observados e aos calcu lados pela relação preconizada por VASọUES FILHO (1972), são apresentados no quadro 33.

A razão de comprimentos médios exibiu comportą mento semelhante aos da razão de ramificação e razão de comvri mentos totais, mostrando variações dentre da mesma unidade de solo e sendo inconsistente para a distinção dos solos, confir mando SOUZA (1975) e CARVALHO (1977) e divergindo de FREIRE (1977). Os valores determinados pela relação preconizada foram bastante inferiores aos da média observada, estando em confor midade com os resultados de VASQUES FILHO (1977) e FREIRE (1977) e discordando dos de souza (1975).

5.2.2.2. Análise conjunta dos elementos da com posição dà rede de drenagem, determina dos em bacias hidrográficas

Os valores dos números de segmentos de rios 


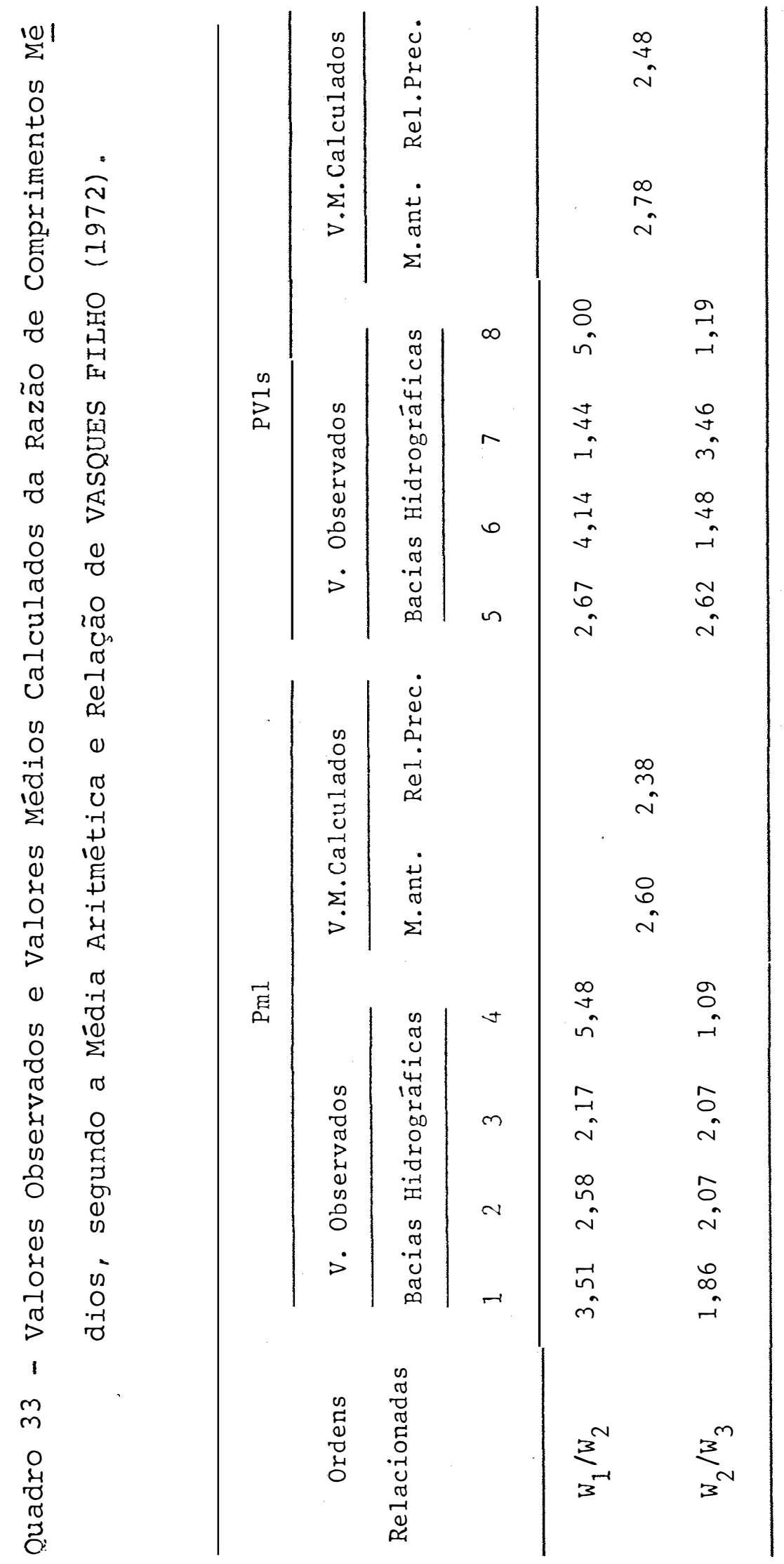


comprimentos médios e totais dos segmentos de rios são apresen tados no quadro 34, sendo agrupados os valores observados, os valores determinados segundo as relações preconizadas e os va lores determinados pelas leis de Horton.

Os valores médios das razões de ramificação, com primentos totais e de comprimentos médios, determinados pela média aritmética, relações preconizadas e relação $\mathrm{P} . \mathrm{lm}=\mathrm{Pb} / \mathrm{R} l \mathrm{l}$, são apresentados no quadro 35 .

A análise conjunta dos elementos números e com primentos totais e médios de segmentos de rios, permite desta car a maior eficiência dos comprimentos médios e a menor apti dão dos comprimentos totais para a distinção das áreas de so los, fato que diverge de SOUZA (1975) e FREIRE (1977).

De maneira geral, os critérios de determinação, média ponderada e lei de Horton foram equivalentes e apresenta ram dados distintos dos das relações preconizadas. Por este fa to observou-se a conveniência de se realizar a análise con junta dos elementos baseada num mesmo critério de determinação, confirmando SOUZA (1975).

A análise conjunta dos elementos razão de ramifi cação, razão dos comprimentos totais e razão dos comprimentos médios, permitiu destacar a ineficiência dos três elementos na diferenciação dos solos estudados. Este fato diverge dos resul. tados da literatura consultada, podendo, entretanto, ser exnli 


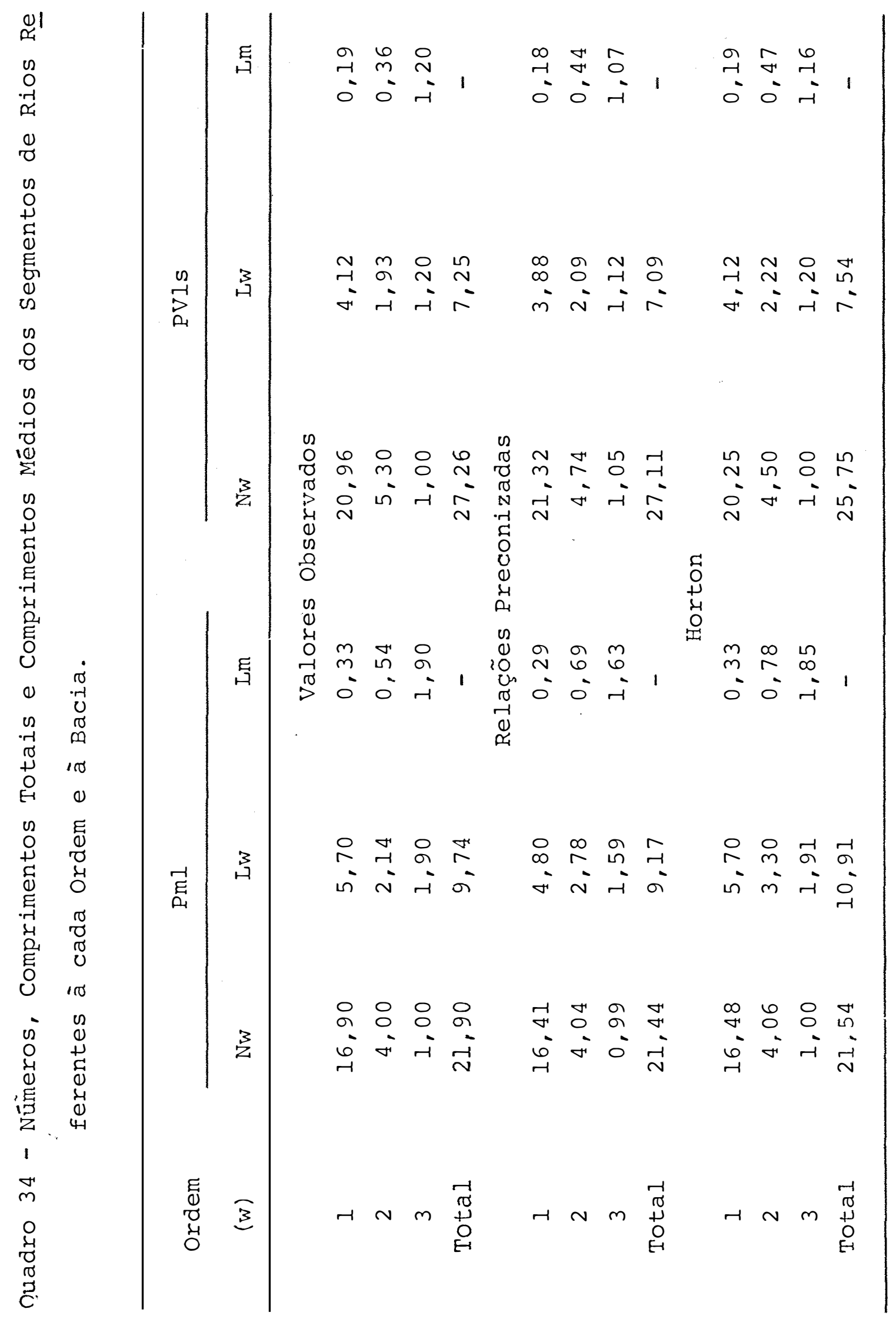




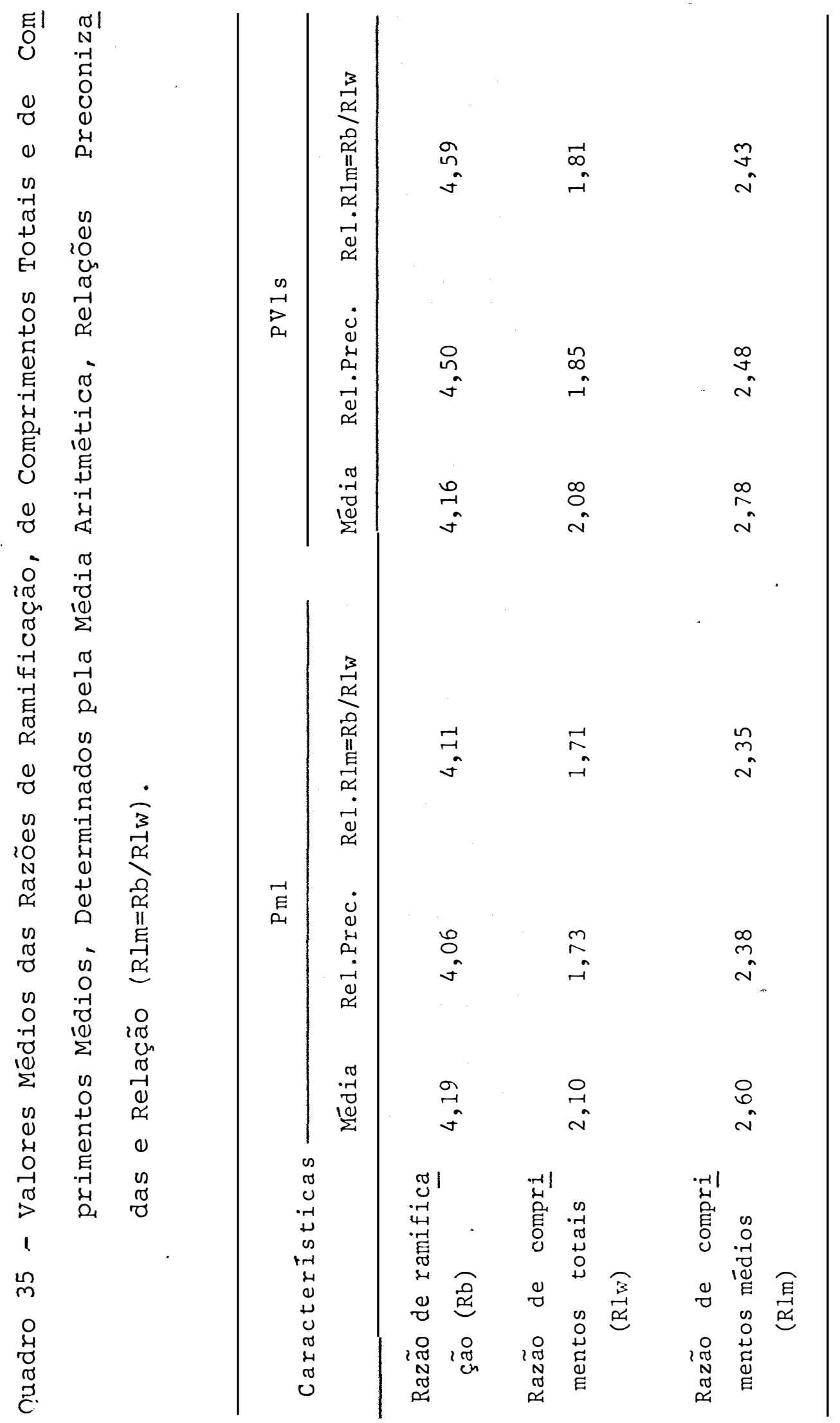


cado pela grande similaridade de condições apresentada nelas duas unidades de solos. Os valores determinados pela relação $\mathrm{Rlm}=\mathrm{Rb} / \mathrm{Rlw}$, preconizada por FRANCA (1968), foram similares aos valores dos antilogarítmos dos coeficientes angulares das relações estabelecidas, mostrando o interrelacionamento $\underline{\text { }}$ xistente entre esses elementos, o que corrobora com FRANCA (1968), LẼ̃o (1973)， GEVAERD (1974) e FREIRE (1977). Os valo res obtidos pela média aritmética foram mais altos que os obtj. dos pelos outros critérios, não se observando a eqquivalência en tre os critérios empregados.

5.2.2.3. Análise dos elementos número, comprị. mento total e comprimento médio dos segmentos de rios das bacias e amos tras circulares

Os valores do número total, comprimento total e comprimento médio dos segmentos de rios determinados em bacias e amostras circulares são apresentados no quadro 36 e a resnec tiva análise de variância é mostrada no quadro 37.

Os números totais de segmentos de rios, determi nados pelos dois critérios de amoștragem, exibiram diferenças que permitem diferenciar os solos, refletindo as desconformida des do comportamento hidrológico, suportando os resultados de HORTON (1945), STRAHLER (1957) e FRANCA (1968). O critério de 


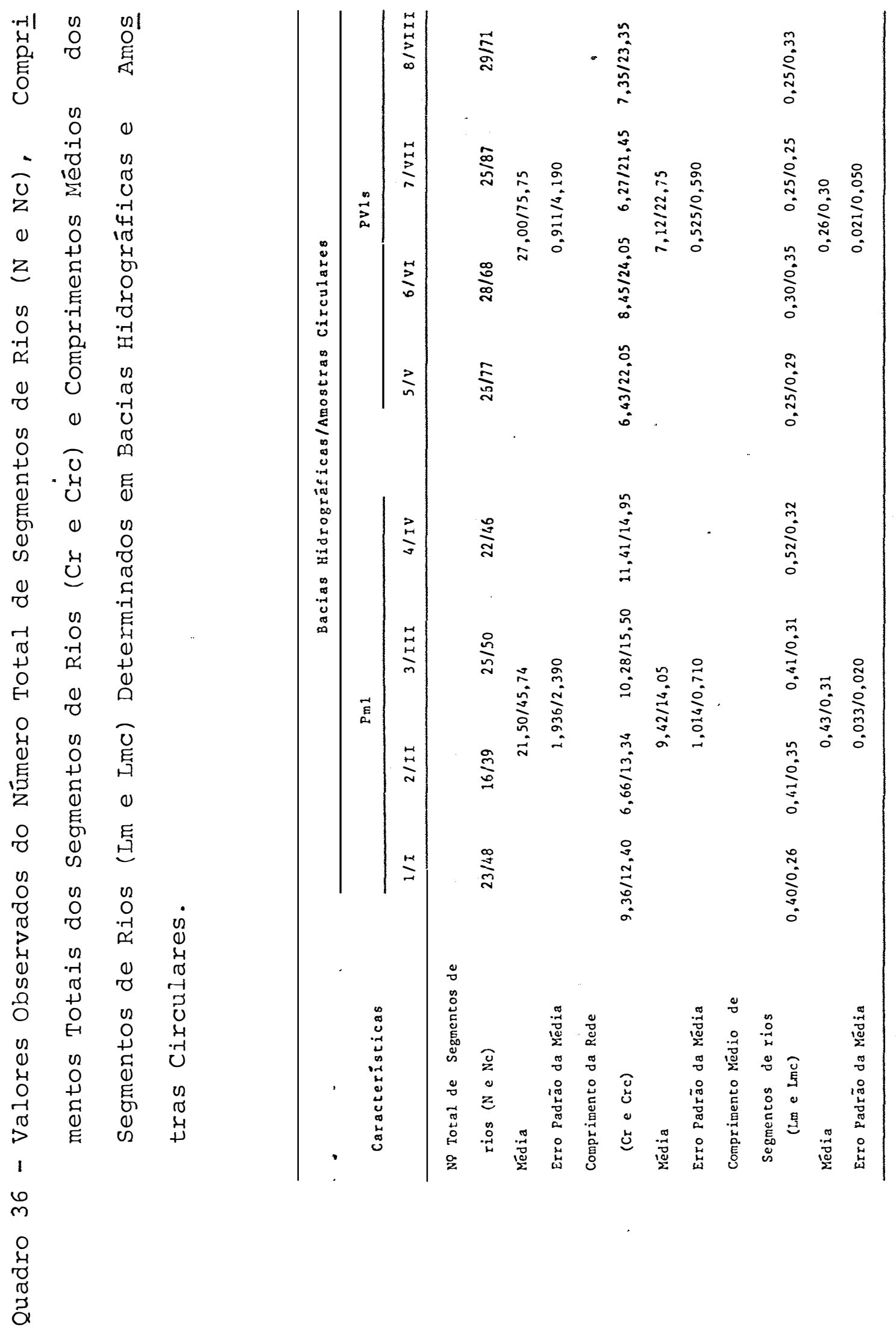




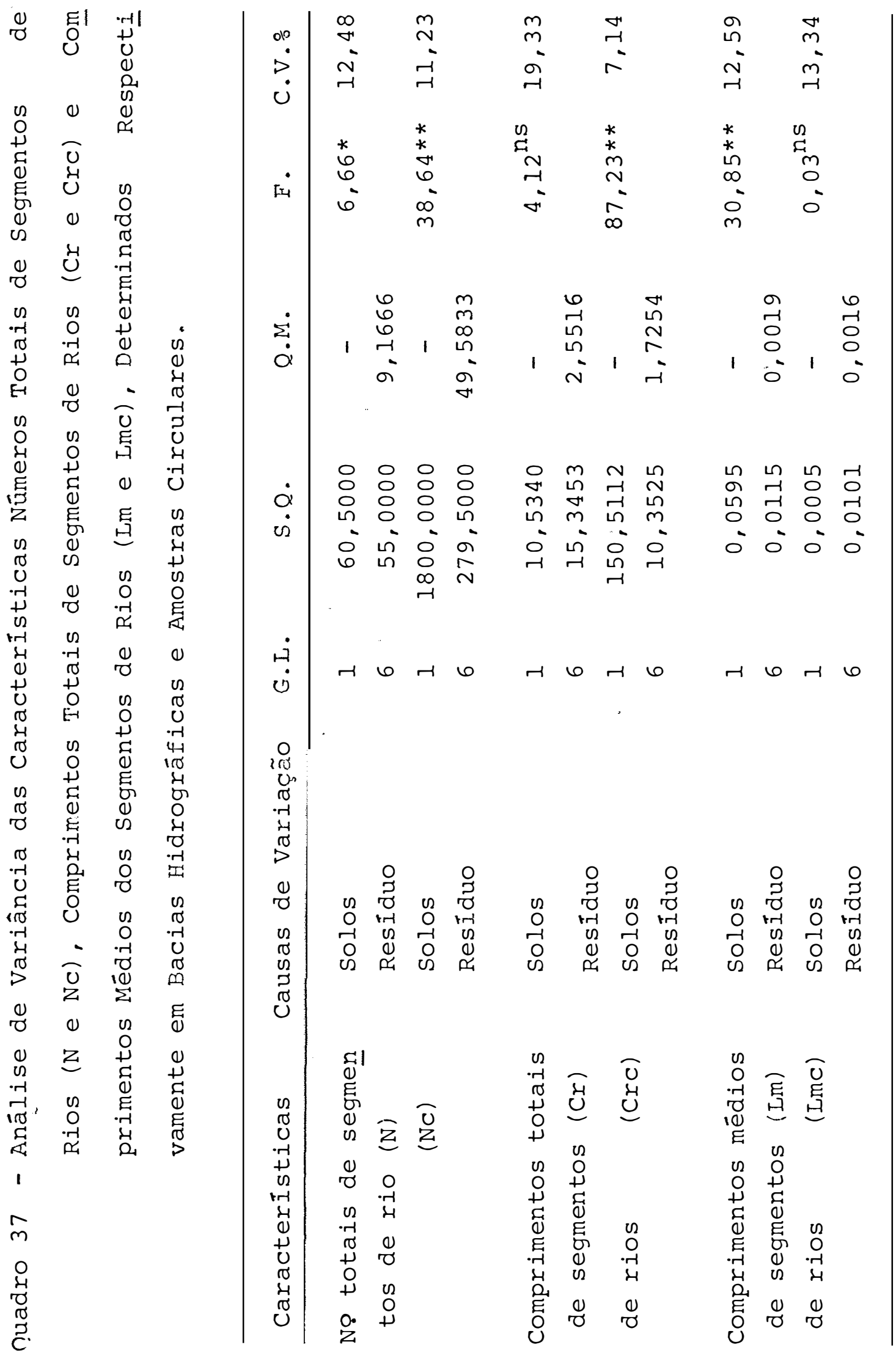


amostras circulares m.sstrou-se mais eficiente nara a referina diferenciação.

O comprimento total de segmentos de rios apre sentou divergências em função do sistema de amostraqem. Para este elemento, os dados determinados nas bacias hidroqráficas não foram consistentes para a distinção dos solos e apresenta ram coeficiente de variação alto, indicando certa heterogenei dade dos dados. Os dados determinados em amostras circulares exibiram diferenças altamente significativas entre solos e apresentaram coeficiente de variação baixo, indicando homoge neidade dos dados. Os resultados obtidos em amostras circula res diferem dos de CARVALHO (1977).

o comprimento médio dos segmentos de rios mos trou comportamento inverso ao do comprimento total. para este elemento o critério bacias hidrográficas foi mais consistente na diferenciação dos solos.

Considerando conjuntamente o comprimento total e o comprimento médio de segmentos de rios inferiu-se a conve niência da utilização simultânea dos dois critérios de amostra gem, para a caracterização adequada da composição da rede de drenagem.

A análise global desses elementos permitiu veri ficar que, de maneira geral, os elementos da rede de drenagem são menos eficientes na diferenciação das áreas de solos que os elementos do padrão, confirmando PARVIS (1950) e LUEDER. 
(1959) e divergindo de vários pesquisadores, como FRANCA (1968) e FADEL (1972).

5.2.3. Relações funcionais entre os elementos do padrão e das bacias de drenagem

No quadro 38 são apresentadas as relações estabe lecidas entre ás diversas características do padrão e das ba cias de drenagem, os respectivos coeficientes de correlação $(r)$ e de determinação $\left(r^{2}\right)$ e as porcentagens da variação total explicada.

Os dados apresentados mostram que, do total de vinte e sete correlações apresentadas, vinte apresentam signi ficação estatística; sendo que treze possuem significação a nI vel de $1 \%$ e sete a nível de 5\%, revelando o alto grau de inter dependência existente entre esses indices.

As relações lineares com significação estatísti ca a nívelde 1\% são apresentadas em seguida.
a - Relação entre frequência de rios ( $(E)$ e densi dade de drenagem (Dd)

A relação funcional estabelecida mostrou o alto grau de interdependência existente entre esses indices, inde pendentemente da unidade de solo. Revelou que o tipo de rela ção existente entre o número e o comprimento de rios por unida de de área dos sistemas de drenagem estudados é o diretamente 


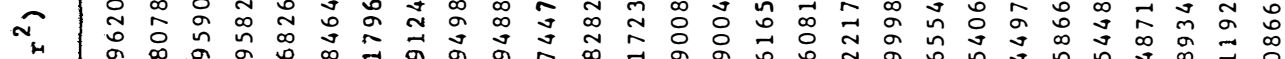

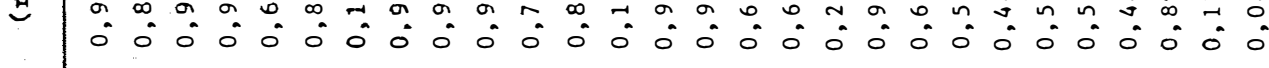

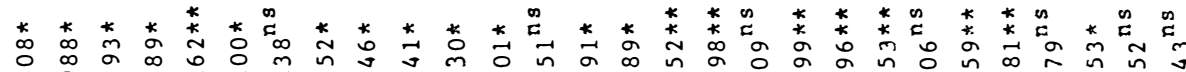

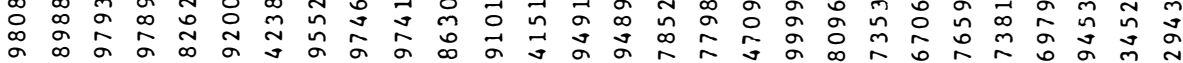

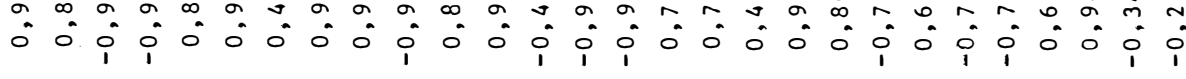

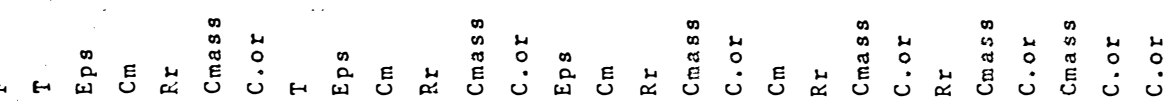

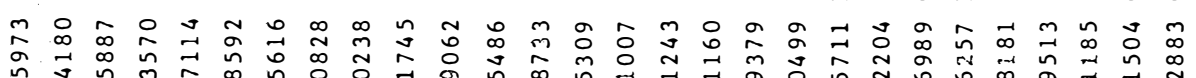

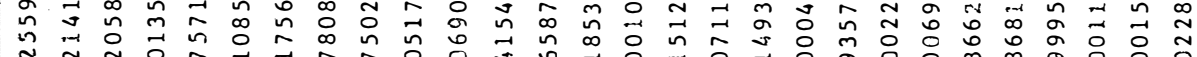

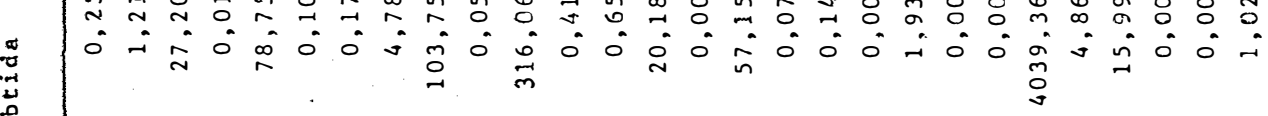

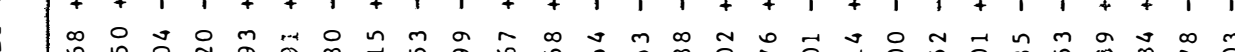

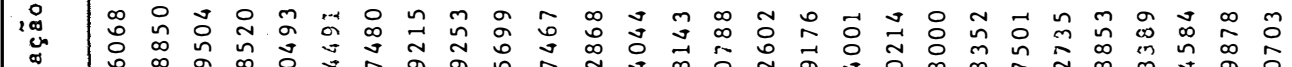

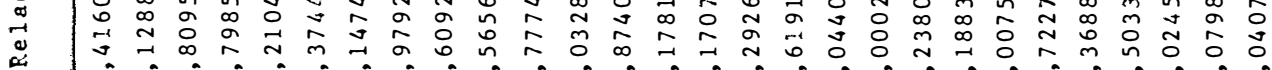
- $\begin{gathered}1 \\ 1\end{gathered}$

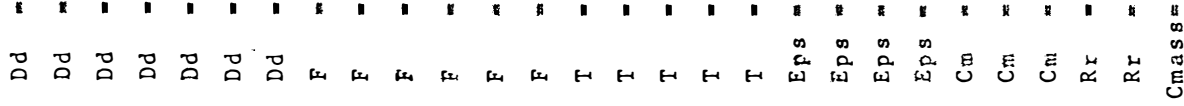

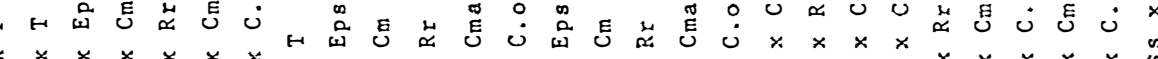

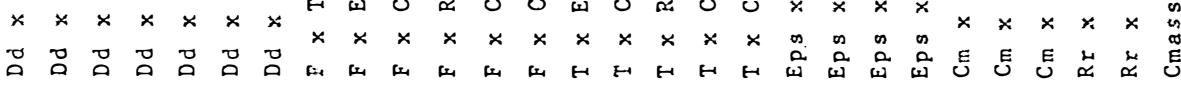


proporcional, indicando que as āreas mais dissecadas apresen tam maiores comprimentos dos canais escoadouros por unidade de área. O coeficiente de correlação indicou pequena variação na interdependência desses índices e a porcentagem de variação total explicada foi muito alta. Os resultados obticos confir mam VASQUES FILHO (1972) e CARVALHO (1977) e corroboram com os de GEVAERD (1974), SOUZA (1975) e FREIRE (1977) que, empreqan do valores médios desses elementos, obtiveram resultados simi lares.
b - Relação entre razão de textura (T) e densidą de de drenagem (Dd)

Verificou-se a existência de relação estreita en tre o número de rios por unidade de perímetro e o comprimento de rios por unidade de área. A relação estabelecida está em conformidade com VASQUES FILHO (1972) e CARVALHO (1977) e di verge de SMITH (1955) e FADEL (1972), cujos dados se ajustaram, respectivamente, à equações dos tip̣os potencial e exponencial e de FREIRE (1977), que obteve coeficiente de correlação não significativo, embora este autor tenha utilizado os valores mê dios destes indices.

C - Relação entre extensão do percurso superfí cial (Eps) e densidade de drenagem (Dd)

Por esta relação foi verificada a alta interde pendência existente entre o tamanho das encostas e o comprimen 
to de rios por unidade de área. Sendo a relação obtida inversa mente proporcional, significa que nas āreas de interflinvios muito extensos o comprimento de rios por unidade de ārea será pequeno. Estes resultados evidenciam a imp̣ortância do indice extensão do percurso superficial na caracterização de bacias e sistemas de drenagem.

d - Relação entre coeficiente de manutenção $(\mathrm{Cm})$ e densidade de drenagem (Dd)

Verificou-se a alta interdependência existente entre a área de drenagem correspondente a cada unidade de com primento de canal escoadouro e o comprimento de rios por unida de de área. Essa relação, sendo inversamente proporcional, in dica que nas áreas de relevo menos dissecado será menor o com primento de canais por unidade de área.

$$
\begin{aligned}
& \text { e - Relação entre coeficiente de massividade } \\
& \text { (Cmass) e densidade de drenagem (Dd) }
\end{aligned}
$$

Esta relação mostra a existência de relação es treita entre condições hipsométricas e comprimentos de rios por unidade de área. Sendo uma relação diretamente proporcio nal, indica que nas āreas de relevos mais ondulados serão mais extensas as redes por unidade de àrea.

f - Relação entre razão de textura (T) e frequên
cia de rios ( $F$ )
o alto grau de interdependência observado, indi 
ca a existência de relação estreita entre números de rios por unidade de área e de perímetro, estando em conformidade com CARVALHO (1977) e divergindo de FADEL (1972) e FREIRE (1977).

g - Relações dos elementos extensão do percurso superficial (Eps), coeficiente de manutenção $(\mathrm{Cm})$, razão de textura $(\mathrm{T})$ e coeficiente de massividade (Cmass) com a frequência de rios ( $F)$

As altas interdependências existentes entre es ses elementos com a frequência de rios, mostraram o tipo de re lação que existe entre comprimento de interflúvio, área de dre nagem correspondente à unidade de canal de escoamento e decli vidade média da bacia, com o número de rios por unidade de área.

h - Relações entre extensão do percurso superfi cial (Eps) e coeficiente de manutenção (Cm) com a razão de textura ( $T$ )

As relações apresentadas evidenciaram 0 alto grau de interdependência existente entre a extensão dos inter flúvios e o número de rios por unidade de perímetro e entre a área de drenagem correspondente à um metro de canal de escoa mento e o número de rios por unidade de perímetro.

i - Relação entre coeficiente de massividade (Cmass) e razão de relevo ( $R r)$

Verificou-se, por esta relação, que as caracte 
rísticas hipsométricas das bacias apresentam alta interdepen dência, indicando, pelo tipo de relação obtida, que nas áreas de relevos mais ondulados as declividades médias das bacias se rão maiores.

As relações funcionais cujos coeficientes de cor relação apresentaram-se significativos a nível de 5\% de proba bilidade são as estabelecidas entre os indices: razão de rele vo e densidade de drenagem; razão de relevo e razão de textü ra; coeficiente de massividade e razão de textura; razão de re levo e extensão do percurso superficial; coeficiente de massi vidade e extensão do percurso superficial; razão de relevo e coeficiente de manutenção e, coeficiente de massividade e coe ficiente de manutenção.

Por estas relações, embora o grau de significą ção tenha se apresentado menor que no grupo anterior de rela ções, são referendadas as possibilidades da utilização destes Indices no estudo da superfície terrestre objetivando a identí ficação das bacias e redes de drenagem para a diferenciação de comportamentos hidrológicos dos materiais presentes. Verifi cou-se a existência de relações estreitas entre a declividade médja da bacia e o comprimento de rios por unidade de área; a declividade média da bacia e o tamanho das encostas; e a decli vidade média e a área de drenagem correspondente à unidade de comprimento do canal escoadouro.

Verificou-se que o indice coeficiente oroaráfí 
co apresenta dados que não se ajustam ao tipo de relação near.

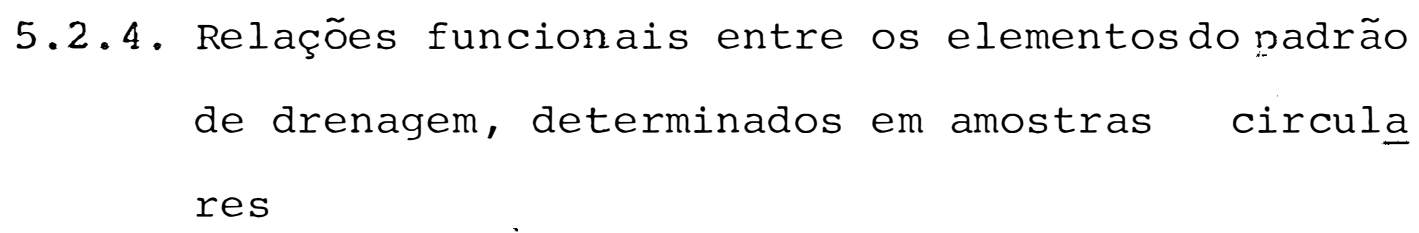

No quadro 39 são apresentadas as relações estabe lecidas entre os indices determinados em amostras circulares.

Do total de dez relações estabelecidas, oito a presentaram significação estatística a nível de lo e duas, a nível de 5\%. A alta eficiência do critério amostra circular na caracterização da rede de drenagem foi evidenciada pelos resul tados observados, onde se constatou, de maneira geral, pequena dispersão dos dados e alta porcentagem dà variação total expli cada.

As relações que apresentaram coeficientes de cor relação significativos a nível de l\% são apresentadas em sequi da.

a - Relação entre frequência de rios (FC) e den sidade de drenagem (DdC)

Eșta relação mostrou o alto grau de interdepen dência existente entre o número e comprimento de rios por uni dade de área, confirmando os resultados de KOFFLER (1976), CPP. VALHO (1977) e FREIRE (1977) e suportando os resultados de CE 
$E$
0
0
0
0
0
0
7
5
0
0
+1
0
0

Ė

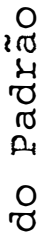

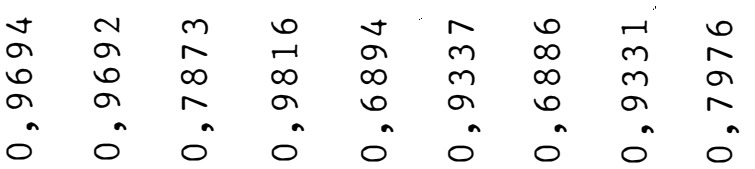

$+4$

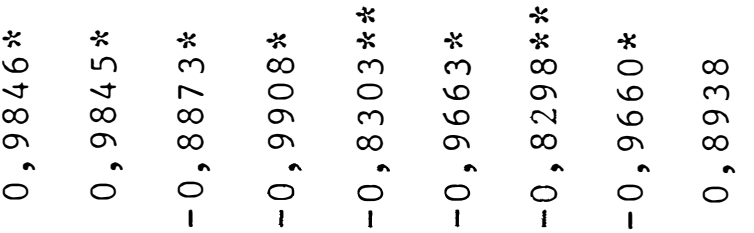

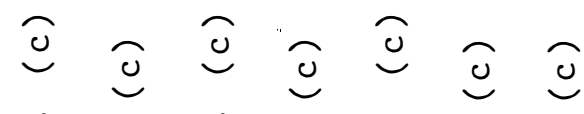

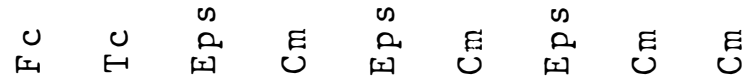

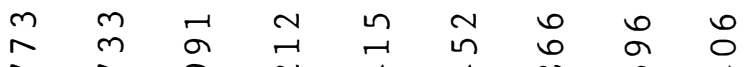

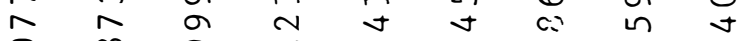

$\begin{array}{lllllllllllllll}0 & \infty & n & N & m & n & N & N & 0\end{array}$

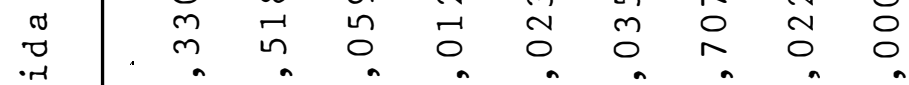

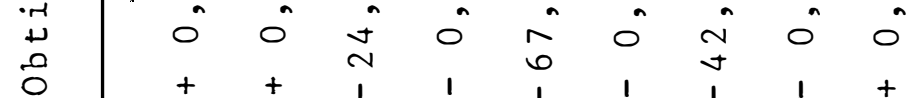

0

㞱

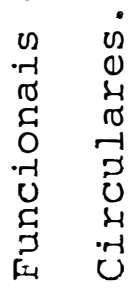

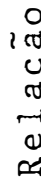

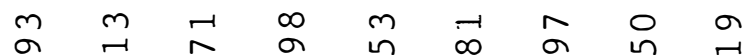

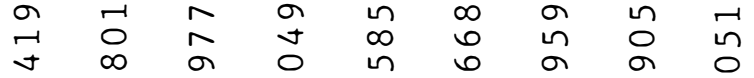

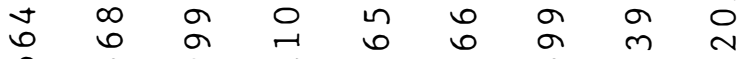

0 b a $N$ m $m$ r $m 0$

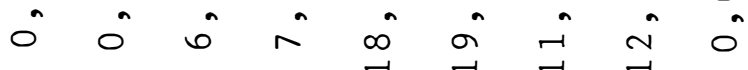

॥ $\|$ ॥ ॥

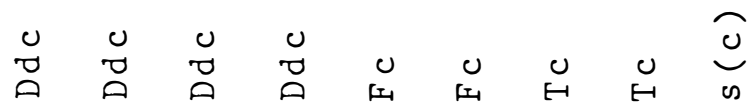

n $n$

00

Un

藏

1

m

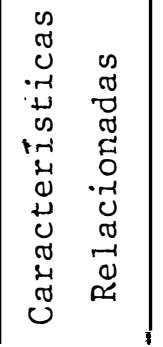

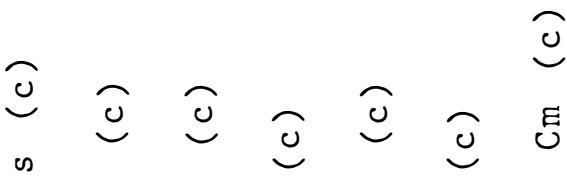

$\begin{array}{lllll}0 & 0 & 0 & 0 & x\end{array}$

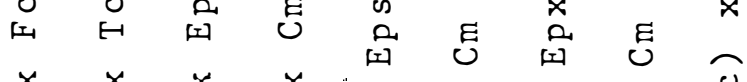

$x \times x \times \begin{array}{lllll}0 & x & x & x & 0\end{array}$

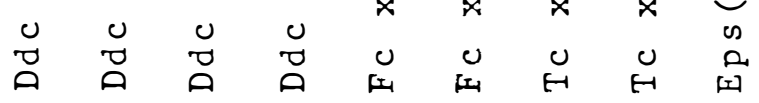


VAERD (1974), SOUZA (1975) e VALERIO FILHO, HIGA e CARVALHO (1976), que empregaram valores médios destes indices.

b - Relação entre razão de textura (TC) e densi dade de drenagem (Ddc)

A relação estreita obtida para número derios por unidade de perímetro e comprimento de rios por unidade de área, está em conformidade com KOFFLER (1976), CARVALHO (1977) e FREIRE (1977) e diverge dos resultados de GEVAERD (1974), gue obteve coeficiente de correlação não significativo. Sequndo KOFFLER (1976), a alta interdependência entre a razão de textü ra e a densidade de drenagem será esperada quando for verifica do esse grau de interdependência entre frequência de rios e densidade de drenagem, porque nas amostras circulares é mantida constante a relação área/perímetro.

$$
\begin{aligned}
& \text { c - Relação entre extensão do percurso superfí } \\
& \text { cial (Epsc) e densidade de drenagem (Ddc); } \\
& \text { coeficiente de manutenção (Cmc) e densidade } \\
& \text { de drenagem (Ddc); coeficiente de manutenção } \\
& \text { (Cmc) e frequência de rios (Fc); e coeficien- } \\
& \text { te de manutenção (Cmc) e extensão do percur } \\
& \text { so superficial (Epsc). }
\end{aligned}
$$

Os altos graus de interdependência das caracte rísticas relacionadas referendaram a constatação sobre a impor tância dos Indices extensão do percurso superficial e coefici ente de manutenção na caracterização das redes de drenagem. 
As relações lineares que apresentaram coeficien tes de correlação significativos a 5\% são as estabelecidas en tre: a extensão do percurso superficial (Epsc) e frequência de rios (FC); e a extensão do percurso superficial (Ep̣c) e a ra $z$ ão de textura (TC). Estas relações referendaram a importância destes índices na diferenciação de áreas de solos.

5.2.5. Relações funcionais entre os elementos do pạ drão de drenagem determinados pelos dois crité rios de amostragem

No quadro 40 são apresentadas as relações funcio nais estabelecidas dentre os elementos do padrão de drenagem, determinados em bacias hidrográficas e amostras circulares.

Os resultados apresentados mostraram coeficien tes de correlação altos, sendo que, das vinte e cinco relações estabelecidas, vinte exibiram significação a nível de $1 \%$ e cin co, a nível de 5\% de probabilidade. Pelos resultados, esses Indices do padrão de drenagem são correlacionáveis entre si, indenpendentemente do critério de amostragem e da natureza dos solos estudados. Suas importâncias na diferenciação dos solos foram, mais uma vez, ressaltadas. 
0
0
$E$
0
0
0
$E$
0
0
0

$\pi$

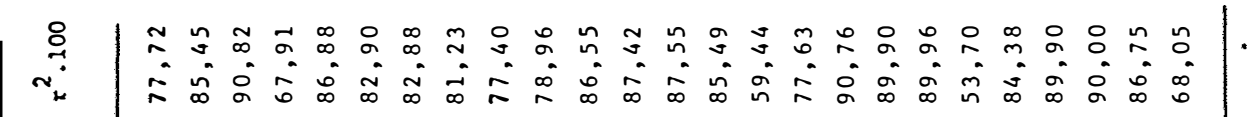
1

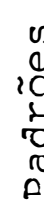

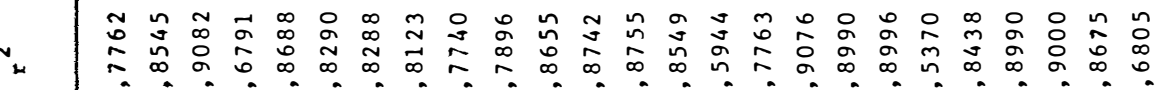

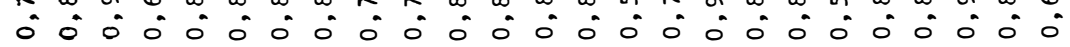

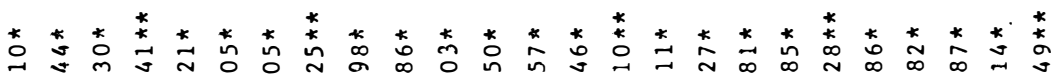

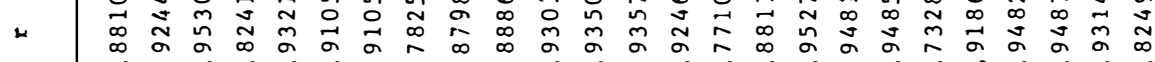

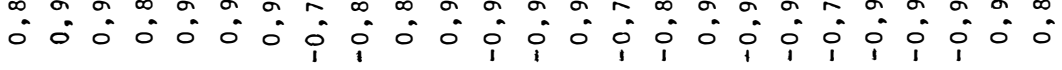

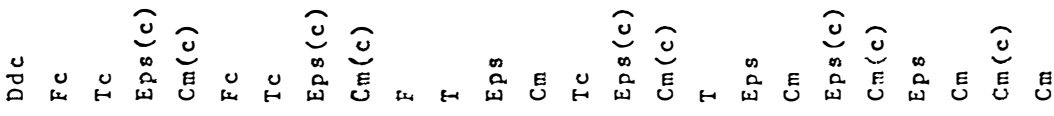

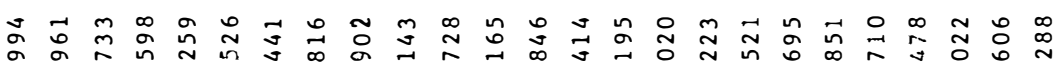

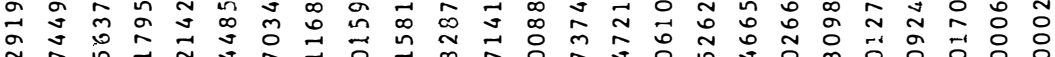

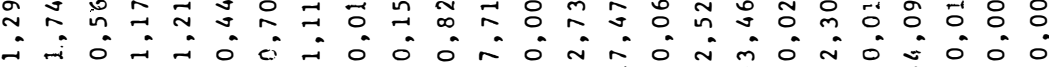

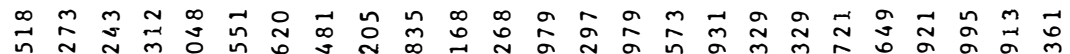

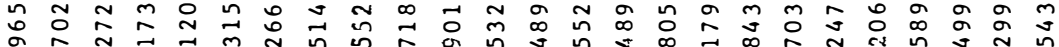
क

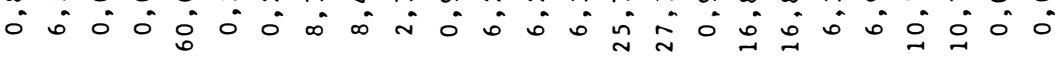

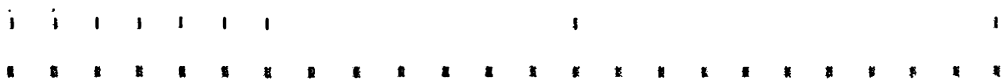

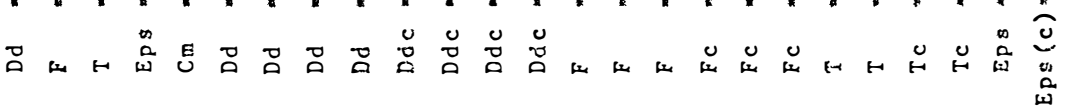
品 
5.3. Sintese dos Resultados

Os dados obtidos, suas análises e interpretações permitiram verificar os seguintes fatos.

a - Bacias Hidrográficas

As características não dimensionais, forma e si metria das vertentes, apresentaram variações dentro da mesma unidade de solo e não foram distintas entre unidades.

As características dimensionais, área, perímetro, maior comprimento, maior largura e comprimento do rio princi pal, apresentaram diferenças significativas entre solos, enquan to que o comprimento total da rede e os índices de circularidą de e compacidade não apresentaram.

As características dimensionais, determinadas pe la análise hipsométrica, razão de relevo e coeficiente de mas sividade mostraram diferenças altamente significativas entre os solos, enquanto que a integral hipsométrica e o coeficien te orográfico não revelaram diferenças.

As curvas hipsométricas revelaram diferenças dos estágios do ciclo erosivo dos relevos das áreas de solos.

b - Padrão de Drenagem

As características descritivas, tipo ou modelo, densidade, orientação, grau de controle e angularidade, exibí ram diferenças entre solos, embora com significados subjeti 
vos.

As características quantitativas, densidade de drenagem, razão de textura, frequência de rios, extensão do percurso superficial e coeficiente de manutenção mostraram di ferenças significativas entre solos, independentemente dos cri térios de amostragem.

As classes de textura topográfica variaram em função dos solos e dos critérios de amostragem.

A ordem decrescente, em termos de eficiência poa ra a separação dos solos, foi extensão do percurso superficial, razão de textura, coeficiente de manutenção, densidade de dre nagem e frequência de rios.

Os elementos do padrão foram, de maneira geral, mais consistentes que os da composição da rede, p̣ara a diferen ciação dos solos.

c - Composição da rede de drenagem

Os nümeros de segmentos de rios apresentaram di ferenças significativas entre solos.

Os dados observados dos números de segmentos de rios mostraram ajustamento adequado à relação preconizada nor MAXWELL (1955).

Os nūmeros de segmentos de rios obedeceram à lei de Horton. 
A razão de ramificação exibiu variações dentro da mesma unidade de solo e não foi eficiente para diferenciar os solos.

Os comprimentos totais dos segmentos de rios, nas bacias hidrográficas, apresentaram variações não significatị vas e, nas amostras circulares, diferenças significativas en tre solos.

Os dados observados dos comprimentos totais, na unidade Solos Podzolizados de Lins e Marília - var. Marília, não mostraram ajustamento adeđuado às relações de RRANCP (196\%) e STRAHLER (1957) e os dados referentes à unidade solos dođzó lico Vermelho-Amarelo - var. Laras revelaram comnortamento in verso. O ajustamento foi melhor na relação de strahler.

Os comprimentos totais obedecem à lei de Horton.

A razão de comprimentos totais apresentou compor tamento semelhante ao da razão de ramificação.

Os comprimentos médios dos segmentos de rios exi biram diferenças significativas entre solos, nos dados referen tes às bacias hidrográficas e não exibiram essas diferenças nos dados das amostras circulares, revelando comportamento inverso ao dos comprimentos totais.

Os comprimentos médios não apresentaram ajustą mento adequado à relação de VASQUES FILHO (1972).

Os comprimentos médios obedecem à lei de Horton. 
A sequência, comprimentos médios, números de rios e comprimentos totais, representa a ordem decrescente, em termos de eficiência para a diferenciação de solos.

Nem sempre os diferentes critérios de determina. ção do mesmo elemento. foram equivalentes, verificando-se a necessidade de se realizar a análise conjunta sempre " baseada num mesmo critério.

A razão dos comprimentos médios mostrou comporta mento similar aos das demais.

d - Relação Entre os Elementos do Padrão e da Bä cia

- Todos os indices mostraram alto grau de interde pendência, excetuando o coeficiente orográfico.

e - Relação Entre os Elementos do Padrão, Deter minados em Amostras Circulares

Todos os indices apresentaram alto grau de inter dependência.

f - Relação Entre os Elementos do Padrão, Deter minados Pelos Dois Critérios de Amostragem

Todos os indices se apresentaram correlacioná veis entre si e com altos graus de interdependência, indepen dentemente do sistema de amostragem e da natureza do solo.

Verificou-se para os diversos elementos da ba cia, do padrão e da composição da rede, inúmeras divergências 
entre os dados da literatura e mesmo entre os dados observados e os da literatura, fato que deve estar associado ao problema da comparação entre tipos de solos. A ommparação entre solos bem diferenciados pode fornecer resultados diferentes daqueles oㅁ tidos pela comparação de solos similares. 


\section{CONCLUSÖES}

Pelas verificações efetuadas, nas condições em que se desenvolveu este trabalho, pode-se tirar as sequintes conclusões:

a - A análise morfométrica permitiu a diferencia ção das áreas dos solos estudados, refletindo diferenças da re lação infiltração/déflúvio, permeabilidade, armazenamento d'a gua, profundidade do estrato rochoso e diferenças no estáxio da erosão;

b - A fotografia aérea foi eficiente para a aná lise morfométrica da paisagem dos solos estudados;

c - Os Índices do relevo foram tão eficientes quanto os da rede de drenagem para a diferenciação pretendida: d - Os critérios de amostragem utilizados foram adequados para a realização da análise morfométrica, destacan do-se a superioridade do critério amostras circulares e,

e - E necessária a continuação dos estudos realí 
155.

zados para se verificar até que nível as diferenças entre so los permitem a diferenciação das āreas de ocorrência. 


\section{SUMMARY}

The scope of this work was to study quantitative ly and qualitatively the significance of morphometrical analy sis of the landscape components as the relief and drainage net work on the soils differentiation, by means of aerial photo graphs.

Two individual soil belonging to the mapping unit Red-Yellow Podzolic Soils were selected to this study because they showed common characteristics as climatic conditions and the presence of argillic horizon.

The soil units chosed were the Lins Marilia Pod zolic Soils - Marilia variation and Red-Yellow Podzolic Soils - Laras variation situated respectively in the north region of the State of São Paulo, in occidental plateau, and in a paleo zoic Depression, both of them under mesothermic climatic condi tions classified as Cwa.

Four representative third order watersheds selec 
ted according to the geometric similarity principle and four circular samples of each of this soils units were used in this study .

The comparative study and discussion of the re sults obtained led to the following conclusions:

a - The morphometrical analysis provide suffi cient informations to distinguished the soils units;

b - The aerial photographs provide sufficient informations for the morphometrical analysis;

c - The elements of the relief were so important than the elements of the drainage network to the pretended dif ferentiation;

d - The watersheds and the circular samples prin ciples were adequated to this morphometrical analysis, with predominance of the second, and

e - Will be necessary the continuation of this studies to verificate the real purpose of the morphometrical a nalysis to distinguish soil areas. 
8. LITERATURA CITADA

AB'SABER, A.N., 1960. Sensibilidade das Fotografias Aéreas em Zonas Tropicais Umidas Para Efeitos de Fotointerpretação. No ticias Geomorfológicas, Campinas, $\underline{3}: 67-72$.

ALMEIDA, F.F.M. de, 1964. Fundamentos qeológicos do relevo paulista. In: SÃO PAULO. Geologia do Estado de São Paulo, São Paulo, Instituto Geográfico e Geológico, p. 169-263. (Bo. letim no 41).

ALOISI, R.R., 1973. Caracterização de Algumas Famílias de so los do Município de Jaboticabal. Jaboticabal, Faculdade de Medicina Veterinária e Agronomia, 157p. (Tese de Doutora mento) .

ANDERSON, H.W., 1957. Relating Sediment Yield to Watershed Variables. Trans. Amer. Geophys. Un., Washington, 38: 921-924 .

AUDI, R., 1972. Fotointerpretação de Atributos dos Canais de Drenagem em Solos da Região Noroeste do Estado de São 
Paulo. Piracicaba, ESALQ/USP, 182p. (Tese de Doutoramen to).

AVERY, T.E., 1968. Interpretation of Aerial Photographs. Min neapolis, Burgess Publishing Company. 319p.

BELCHER, D.J., 1945. The Engeneering Significance of Soil Pat terns. Photogram. Eng., 11:115-148.

BOMBERGER, E.H. e H.W. DILL, 1960. Photo interpretation in agriculture. In: AMERICAN SOCIETY OF PHOTOGRAMMETRY. Ma nual of Photographic Interpretation. Washington, Am. Soc. of Photogrammetry, p.561-666.

BUOL, S.W.; F.D. HOLE e R.J. MCCRACKEN, 1973. Soil Genesis and Classification. Ames, The Iowa State University Press. $299 p$.

BURGOS, J.J. e A.L. VIDAL, 1951. Los Climas de la Republica Argentina Segun la Nueva Classification de Thornthwaite. Bue nos Aires, Serv. Meteor. Nac. 30p.

BURINGH, P., 1954. The Analysis and Interpretation of perial Photographs in Soil Survey and Land Classification. Neth. J. Agric. Sci., Wageningen, 2:16-26.

BURINGH, P., 1960. The applications of aerial photographs in soil surveys. In: AMERICAN SOCIETY OF PHOTOGRAMMETRY. Ma nual of Photographic Interpretation. Washington, Amer. Soc. of Photogrammetry, p.633-666. 
CARVALHO, W.A., 1977. Fotoinberpretação de Bacias Hidrog̣ráfí cas e Amostras Circulares de Redes de Drenagem de Solos com Horizonte B Textural. Piracicaba, ESALQ/USP, 126p. (Tese de Doutoramento).

CHAPMANN, C.A., 1952. A New Quantitative Method of Topoqraphi cal Analysis. American Journal Sci. New Aveni, 250:428: -452 .

CHRISTOFOLETTI, A., 1969. Aná lise Morfométrica das Bacias Hi drográficas. Noticias Geomorfológicas. Campinas, 9:35-64.

CHRISTOFOLETTI, A., 1974. Geomorfologia. São Paulo, Ed. Uni versidade de são Paulo. $149 \mathrm{p}$.

CHRISTOFOLETt, A. e A.L. CESAR, 1978. Correlação Entre Densí dade de Drenagem e Comprimento Médio de Canais em Bacias Hi drográficas. Ciência e Cuztura. São Paulo, 5:501-601.

COLWELL, R.N., 1952. Photographic interpretation for civil pur poses. In: AMERICAN SOCIETY OF PHOTOGRAMMETRY. Manual of Photogrammetry. Washington, p.535-602.

COMISSÃO DE SOLOS, 1960a. Levantamento de Reconhecimento dos Solos do Estado de São Paulo. Rio de Janeiro, Centro Nacio ' nal de Ensino e Pesquisas Agronômicas. 634p. (Boletim no i7).

COMISSÃO DE SOLOS, 1960b. Carta dos Solos do Estado de são Paulo. Rio de Janeiro, Centro Nacional de Ensino e Pesaúi sas Agronômicas. (folha única). 
CRESWICK, W.J. e W.H. ROCKWELL, 1959. Aplications of aerial photographic techniques to agricultural surveys. In: LUEDER, D.R. Aerial Photographic Interpretation: Principles and Ap plications. New York, Mc Graw Hill, p.373-385.

DAVIS, R.E.; F.S. FOOTE E J.E. KELLY, 1966. Surveying-Theory And Pratice. New York, Mc Graw Hill Book Company. 1196p. DEPARTAMENTO NACIONAL DE PESỌUISA AGROPECUARIA, 1971. Levanta mento de Reconhecimento dos Solos do Sul do Estado de Mato Grosso. Rio de Janeiro, Ministério da Agricultura. 839p̣.

ESPINDOLA, C.R. e J.C. GARCIA, 1978.' Interpretação Fotơráfí ca de Redes de Drenagem em Diferentes Categorias de Solos. Noticias Geomorfológicas. Campinas, $\underline{8}: 71-94$.

ESPINDOLA, C.R., 1977. Relações Entre os Solos e Elementos da Paisagem na Zona do Baixo Rio do Peixe (Região de Conchas-Anhembí - SP). Piracicaba, ESAL@/USP, 113p. (Dissertação de Mestrado).

FADEL, H., 1972. Fotointerpretação de Bacias e Redes de Drenagem de Três Séries de Solos da Fazenda Ip̣anema, Muni cípio de Araçoiaba da Serra - SP. Piracicaba, EsAlọ/USP, 92p. (Dissertação de Mestrado).

FISCHER, W.A.; P. BADGLEY,; D.G. ORR e C.J. ZISSIS, 1975. His tory of remote sensing. In: REEVES, R.G.; ANSON, A.E. e D. LANDEN. Manual of Remote Sensing. Virginia, American So ciety of Photogrammetry, p.27-50. 
FRANÇA, G.V., 1968. Interpretação Fotográfica de Bacias e de Redes de Drenagem Aplicada a Solos da Região de Piracicaba. Piracicaba, ESALQ/USP, 156p. (Tese de Doutoramento).

FREIRE, J.C., 1977. Fotointerpretação de Redes de Drenagem de Três Solos da Região de Alpinópolis, Minas Gerais. Pirací Caba, ESALQ/USP, 136p. (Tese de Doutoramento).

FREITAS, R.O., 1952. Textura de Drenagem e Sua Aplicação Geo morfologica. Boletim Paulista de Goegrafia. São Paulo, $11: 53-57$.

FROST, R.E., 1960. Photo interpretation of soils. In: AMERI CAN SOCIETY OF PHOTOGRAMMETRY. Manual of Photographic In terpretation. Washington, Am. Soc. of photogrammetry, $D$. 343-402.

GALHEGO, H.R., 1979. Relações Entre Relevo e Pedogênese em Ma teriais Argilosos da Zona do Médio Tietê (Região Tatuí-Gua reí-SP). Botucatu, FCAB/UNESP, 116p. (Tese de Livre Docên cia).

GARCIA, G.J., 1975. Fotointerpretação Comparativa de Fotorra fias Pancromáticas, Coloridas e Infravermelhas Coloridas (Falsa Cor). Piracicaba, ESALọ/USP, 1llp̣. (Tese de Doutó ramento).

GARCIA, G.J., 1979. Técnicas de Sensoriamento Remoto na Ava liação do Potencial do Uso de Regiões de Cerrado. Botucatu, FCAB/UNESP, 135p. (Tese de Livre Docência). 
LANGBEIN, W. B. et alii. 1947. Tonogranhic characteristj.cs of drainage basins. In: TOEBES, C. e ORRYiNEV, Renresentitive and Experimental Basins. Paris, unESro, 1970. $343 \mathrm{p}$.

LEÃO, S.R.F., 1973. Interpretação Fotográfica dos Padrões de Drenagem Desenvolvidos em Dois Solos do Distrito Federal. Piracicaba, ESALQ/USP, 110p. (Disserțação de Mestrado).

LEmos, R.C. de. e R.D. dos SAntos, 1976. Manual de Método de Trabalho de Campo. Campinas, Sociedade Brasileira de Ciên cia do solo. $36 \mathrm{p}$.

LOPES VERGARA, M.L., 1971. Manual de Fotogeologia. Madrid, Servicio de Publicaciones de la Junta de Energia Nuclear. $286 p$.

LUEDER, D.R., 1959.. Aerial Photographic Interpretation: Prin ciples and Aplications. New York, Mc Graw Hill Book Comna ny, Inc. $462 \mathrm{p}$.

MARCHETTI, D.A.B., 1969. Fotointerpretação de A.tributos do Re levo Aplicada a Solos da Região de Piracicaba. Piracicaba, ESALO/USP, 58p. (Tese de Doutoramento).

MARQUES, J.o.A., 1971. Manual Brasizeiro Para Levantamento - da Capacidade de Uso da Terra. Rio de Janeiro, Escritório Técnico Brasil-Estados Unidos. $433 \mathrm{p}$.

MAXWELL, J.C., 1955. The Bifurcation Ratio in Horton's Law of Stream Numbers. Trans. American Geophys. Union. New Ha ven, $36: 520$. (Resumo). 
GEVAERD, I., 1974. Parâmetros Fotoanalíticos de Solos da Re gião Nordeste Paranaense. Piracicaba, ESALO/USP, 110p. (Dís sertação de Mestrado) .

GOOSEN, D., 1968. Interpretacion de Fotos Aéreas y Su Impor tancia en Levantamiento de Suelos. Roma, Organizacion de Las Naciones Unidas Para La Agricultura y La Alimentacion. $58 \mathrm{p}$.

GUERRA, A.T., 1969. Dicionário Geológico-Geomorfológico. Rio de Janeiro, Fundação Instituto Brasileiro de Geografia e Es tatística. 439p.

GUERRA, A.T., 1975. Dicionärio Geológico-Geomorfológico. Rio de Janeiro, Fundação Instituto Brasileiro de Geografia e Es tatística. 439p.

HORTON, R.E., 1945. Erosional Development of Streams and Their Drainage Basins: Hidrophysical Approach to nuantitati ve Morphology. Buz. Geol. Soc. Am., Colorado, 56:275-370. JENNY, H., 1958. Role of the Plant Factor in the Pedogenic Functions. Ecology. Brooklyn, 39:5-16.

JOLY, A.B., 1970. Conhęa a Vegetą̃a Brasileira. São Paulo, Eds. Universidade de São Paulo e Polígono. 181p.

KOFFLER, N.F., 1976. Utilização de Imagens Aerofotog̣ráficas e Orbitais no Estudo de Padrões de Drenagem em Solos Originą dos do Arenito de Bauru. São José dos Campos, INPE/CNDCT , 150p. (Dissertação de Mestrado). 
MAZZA, J., 1979. Região Noroeste do Município de Jaboticabal: I. Levantamento de Reconhecimento Com Detalhes dos Solos e 2. Indicação de Práticas Conservacionistas. Jaboticabal, FCAV/UNESP, 127p. (Trabalho de Graduação).

MILLER, V.C. e C.F. MILLER, 1961. Photogeology. New York, MC Graw Hill Ed., 248p.

OLIVEIRA, J.B.; J.R. MENK e C.L. ROTTA, 1979. Levantamento Pe dológico Semidetalhado dos Solos do Estado de São Paulo. Quadricula de Campinas. Rio de Janeiro, Superintendência de Recursos Naturais e Meio Ambiente. 169n.

PAIVA, R.M.; S. SCHATTAN e C.F.T. FREITAS, 1976. Setor Agrico Za do Brasiz. Rio de Janeiro, Ed. Forense Universitária. $480 \mathrm{p}$.

PARVIS, M., 1950. Drainage Pattern Significance in Airphoto Identification of Soils and Bedrocks. Photogramm. Engng.. Washington, 16:387-408.

PENTEADO, M.M. e G. RANZANI, 1971. Aspectos Geomorfológicos e os Solos do Município de Jaboticabal. Geographica. Lisboa, $25: 42-61$.

PENTEADO, M.M., 1970. Fundamentos de Geomorfologia. Rio de Ja neiro, Fundação Instituto Brasileiro de Geografia e Estatís tica. $154 \mathrm{p}$.

PENTEADO, M.M., 1968. Geomorfologia do Setor Centro Ocidental da Depressão Periférica Paulista. Rio Claro, Faculdade de 
Ciências e Letras de Rio Claro, 15lo. (Tese de Doutoramen to).

PIMENTEL GOMES, F., 1963. Curso de Estatistica Experimental. Piracicaba, ESALQ/USP. $384 \mathrm{p}$.

QUACKENBUSH, R.S., 1960. Development of photo interpretation. In: AMERICAN SOCIETY OF PHOTOGRAMMETRY. Manual of Photogra phic Interpretation. Washington, American Society of Photo grammetry. p. 1-18.

RABBEN, E.L., 1960. Fundamentals of photo interpretation. In: AMERICAN SOCIETY OF PHOTOGRAMMETRY. Manual of Photographic Interpretation. Washington, American Society of Photogram metry, p. 99-168.

RANZANI, G.; O. FREIRE e T. KINJO, 1965. Carta de Solos do Mu nicipio de Piracicaba. Piracicaba, CES/ESAL?/USP. 830.

RAY, R.C., 1963. Fotografias Aéreas na Interpretąão e Mapea mento Geológico. São Paulo, Instituto Geográfico e Geoló gico. 163p.

RAY, R.G. e W.A. FISCHER, 1960. A Ọantitative Photographic a Geologic Research Tool. Photogramm. Engn.. Washington, 26: $143-150$.

REEVES, R.G.; A.N. KOLLER; R.J.P. LYON e A.T.U. SMITH, 1975. Terrain and minerals: assessment and evaluation. In: AMERI CAN SOCIETY OF PHOTOGRAMMETRY. Manual of Remote Sensing. Washington, American Society of Photogrammetry. p.1107-1351. 
RICCI, M. e S. PETRI, 1965. Principios de Aerofotogrametria e Interpretą̧a Geológica. São Paulo, Ed. Nacional. 226n. ROURKE, J.D. e M.E. AUSTIN, 1951. The use of Airphotos for Soil Classification and Mapping in the Field. Photogramm. Engng.. Washington, 17:738-741.

RUHE, R.V., 1975. Geomorphology (Geomorphic Processes and Su perficial Geology). Boston, Houghton Mifflin Company. 246 p.

RUHE, R.V., 1969. Quaternary .randscapes em Iowa. Ames,- Iowa State University Press. $108 p$.

SÃo PAULO, 1963. Carta Geológica do Estado de São Paulo. São Paulo, Instituto Geográfico e Geológico. (folha única).

SERVICIO DE CONSERVACION DEL SUELO, s/d. Interpretacion de F́ tografias Aéreas Para La Classificacion y Elaboracion de Cartas Geográficas Del Suelo. México, Centro Regional de Ayuda Técnica Para el Desarollo International, USDA. 89p.

SERVICIO DE FOMENTO Y CONSERVACION DE RECURSOS DE SUELOS, 1977. Guia para la descripcion de Perfiles de Suelo. Poma, Orga nizacion de Las Naciones Unidas Para La Agricultura Y La Alimentacion. $70 \mathrm{p}$.

SCHUMM, S.A., 1956. Evolution of Drainage System and Slopes in Badlands at Perth Amboy, New Jersey. Bul. Geol. Soc. Amer., Colorado, 67:597-646.

SMITH, K.G., 1950. Standards for Grading Texture of Erosional 
Topography. Amer.J.Sci., New Aveni, 248:655-668. SOIL SURVEY MANUAL, 1951. Agriculture Handbook n! 18. Washing ton, USDA. 503p.

SOUZA, M.L.P., 1975. Fotointerpretação das Redes de Drenagem de Três Solos Com Horizonte B Latossólico Ocorrentes no Mu nicípio de Ponta Grossa - PR. Piracicaba, ESAL@/USP, 135p. (Dissertação de Mestrado).

STRAHLER, A.N., 1952. Hypsometric (área-altitude) Analysis of Erosional Topography. BuZl. Geol. Soc. America. Colorado, $63: 1117-1142$.

STRAHLER, A.N., 1957. Quantitative Analysis of Watershed Geo morphology. Transactions American Geophysical. Union. New Haven, $38: 913-920$.

SUMMERSON, C.H., 1954. A Philosophy For Photointerpreters. Photogramm. Engng. Washington, 20:396-397.

TATOR, B.A., 1954. Drainage Annomalies in Coastal Plains Re gions. Photogramm. Engng.. Washington, 20:412-417.

TOLENTINO, M.; N. GANDOLFI e A.B. PARAgUASSU, $1968 . \quad$ Estudo morfométrico das Bacias Hidrográficas do Planalto de são Carlos. Revista Brasizeira de Geografia. são Paulo,30:42-50 .

VALERIO FILHO, M.; N.T. HIGA e V.C. CARVALHO, 1976. Avaliação de Imagens Orbitais (Landsat-l) como Base para Levantamen tos de Solos. São José dos Campos, INPE/CNDCT. 276p. (Dis 
sertação de Mestrado).

VASQUES FILHO, J., 1972. Critérios Morfométricos Aplicados à Fotointerpretação de Redes de Drenagem em Três Unidades de Solos do Município de Piracicaba - SP. Piracicaba, ESAIn/ /USP. 113p. (Tese de Doutoramento).

VILLA NOVA, N. e J.M. SANTOS, 1966. A Classificą̧ão Climätica de William Koeppen. Piracicaba, ESAIn/USP. 12p. (Mimeogra fado) .

ZINKE, P.J., 1960. Photointerpretation of soil. In: AMERICAN SOCIETY OF PHOTOGRAMMETRY. Manual of Photographic Interpre tation., Washington, p.656-560. 